\title{
Recent developments in aminopyrazole chemistry
}

\author{
Hany Fakhry Anwar ${ }^{\mathrm{a}, \mathrm{b} *}$ and Mohamed Hilmy Elnagdi ${ }^{\mathrm{c}}$ \\ ${ }^{a}$ School of Pharmacy, Department of Pharmaceutical Chemistry, University of Oslo, P.O. Box \\ 1068 Blindern, N-0316, Oslo, Norway \\ ${ }^{b}$ Department of Chemistry, Faculty of Science, University of Cairo, Giza, Egypt \\ ${ }^{c}$ Department of Chemistry, Faculty of Science, University of Kuwait, P.O. Box 5969, Safat \\ 13060, Kuwait \\ E-mail: hany.anwar@farmasi.uio.no
}

\begin{abstract}
Recently reported syntheses of 3(5)-aminopyrazoles, 4-aminopyrazoles, and 1-aminopyrazoles as well as of diaminopyrazoles and their general pattern of reactivity towards mono- and bidentate electrophiles have been surveyed. Emphasis has also been laid on techniques for ascertaining the site selectivity in reactions with electrophiles, including single crystal X-ray structure analysis, ${ }^{1} \mathrm{H}-{ }^{15} \mathrm{~N}$ HMBC, and NOE intensity difference experiments as well as other modern 2D NMR techniques. Some thermally induced cycloadditions have also been treated.
\end{abstract}

Keywords: 3(5)-Aminopyrazoles, diaminopyrazoles, pyrazolo[1,5-a]pyrimidines, pyrazolo[3,4b]pyridines, pyrazoldiazonium salts, structure elucidation

\section{Table of Contents}

1. Introduction

2. Synthesis of 3(5)-aminopyrazoles

2.1 Reactions of $\alpha, \beta$-unsaturated nitriles with hydrazines

2.2 Reactions of hydrazines with 3-oxo-alkanenitriles

2.3 Synthesis from substituted hydrazones

2.4 Miscellaneous syntheses

3. Synthesis of 4-aminopyrazoles

3.1 Reduction of 4-nitroso, nitro, and azopyrazoles

3.2 Reaction of arylhydrazononitrile with functionally substituted alkylhalides

3.3 Miscellaneous syntheses

4. Synthesis of 1-aminopyrazoles

5. Synthesis of diaminopyrazoles 
5.1 Synthesis of 3,5-diaminopyrazole and its derivatives

5.2 Synthesis of 4,5-diaminopyrazoles

6. Chemical reactivity of aminopyrazoles

6.1 3(5)-Aminopyrazoles

6.1.1 Reactions with electrophilic reagents

6.1.2 Diazotizations

6.1.3 Halogenation

6.1.4 Acylation

6.1.5 Reactivity toward bidentate electrophiles

6.1.6 Reactions with aldehydes and ketones

6.1.7 Cycloaddition and dipolar cycloadditions

6.1.8 Intramolecular cyclization

6.1.9 Miscellaneous

6.2 4-Aminopyrazoles

6.3 1-Aminopyrazoles

\section{Introduction}

The chemistry of aminopyrazoles has been extensively investigated in the past. ${ }^{1}$ The considerable biological and medicinal activities of pyrazoles ${ }^{2}$ and azolopyrazoles, ${ }^{3}$ for which aminopyrazoles are preferred precursors, have stimulated these investigations. Interest in aminopyrazole synthesis and chemistry has recently been revived. ${ }^{4-8}$ The established activity of Zaleplon (1), ${ }^{9}$ Viagra (2) ${ }^{10}$ as well as Allopurinol (3) ${ }^{11}$ is surely behind this interest (Figure 1).

Chemistry of 3(5)-aminopyrazoles has been reviewed in 1983 by Elnagdi et al. ${ }^{12}$ and more recently in 2004 by El-Taweel and Abu Elmaati. ${ }^{13}$ Significant progress occurred since the publication of these articles. We surveyed these developments and also chemistry of 4aminopyrazoles, and 1-aminopyrazoles as well as chemistry of diaminopyrazoles. These topics to our knowledge have not been surveyed.<smiles>CCN(C)c1cccc(-c2ccnc3c(C#N)cnn23)c1</smiles>

1<smiles>CCCc1nn(C)c2c(=O)[nH]c(-c3cc(S(=O)(=O)N4CCN(C)CC4)ccc3OCC)nc12</smiles>

2<smiles>O=c1nc[nH]c2[nH]ncc12</smiles>

3

Figure 1. Structure of Zaleplon (1), Viagra (2) and Allopurinol (3). 


\section{Synthesis of 3(5)-aminopyrazoles}

These are generally obtained from either reaction of hydrazines with $\alpha, \beta$-unsaturated nitriles, ${ }^{14-16}$ 3-oxoalkenonitriles and hydrazines ${ }^{17-20}$ or reaction of hydrazonoyl halides with active methylenenitriles. ${ }^{21}$ In addition, several other novel routes have been recently reported.

\subsection{Reactions of $\alpha, \boldsymbol{\beta}$-unsaturated nitriles with hydrazines}

This is the most extensively utilized route to 3(5)-aminopyrazoles. Thus aminopyrazole itself was prepared via reacting acrylonitrile (4) with hydrazine hydrate and subsequent cyclization of 5 to yield 6 and dehydrogenation of the latter affording $7 .^{22}$ Compound 7 was directly obtained from reaction $\mathbf{8}$ and hydrazine (Scheme 1$){ }^{23}$

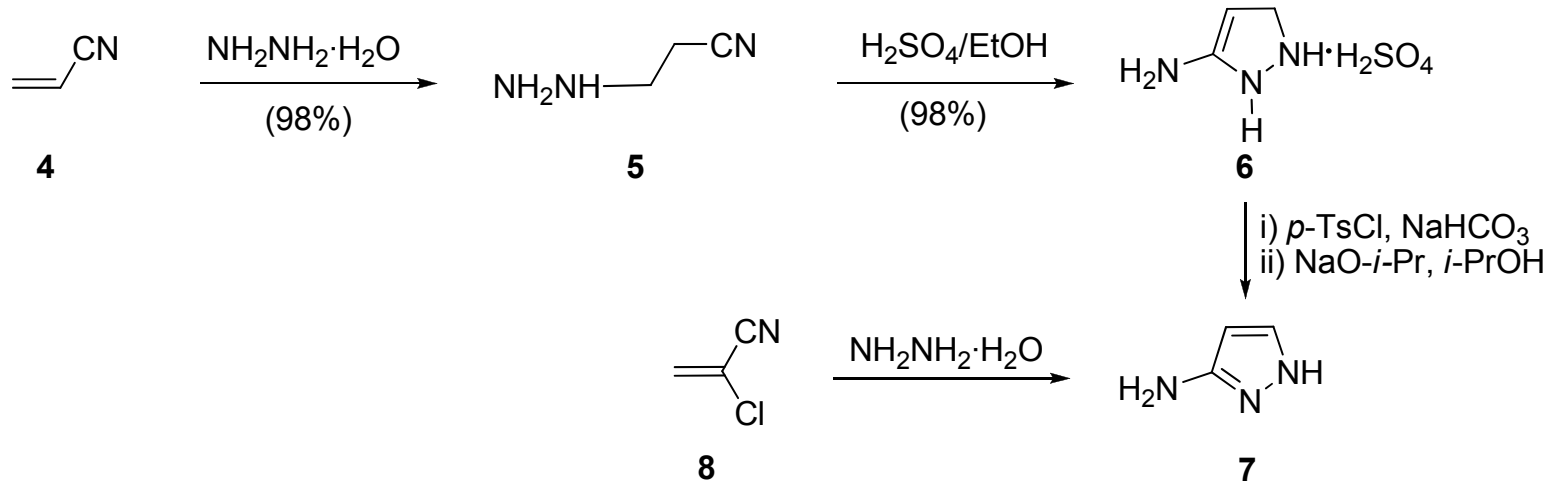

\section{Scheme 1}

Similar syntheses have been extensively employed. Thus, reacting 9 with hydrazine hydrate afforded 10 ${ }^{23-26}$ (Scheme 2). Recently, Quiroga et al. ${ }^{26 c}$ have described the synthesis of 5-amino1-aroylpyrazoles which were prepared from $\beta$-aminocrotononitrile with compounds containing the hydrazine moiety $\left(\mathrm{Z}-\mathrm{NHNH}_{2}, \mathrm{Z}=\mathrm{C}_{6} \mathrm{H}_{5} \mathrm{C}(\mathrm{O})\right.$, aryl-C(O), $\left.\mathrm{H}_{2} \mathrm{NC}(\mathrm{S})\right)$ in the presence of sodium acetate in $80-97 \%$ yields.

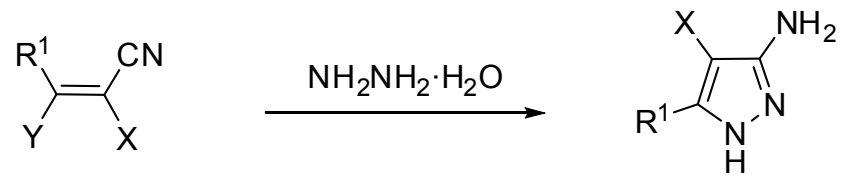

9

10

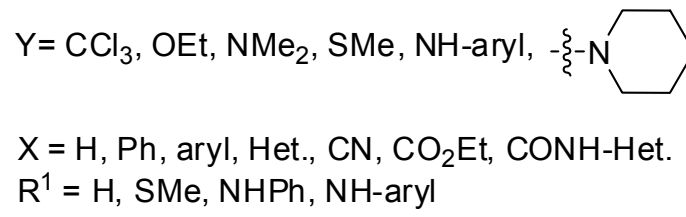

Scheme 2 
Recently, the reaction of arylhydrazines with $\mathbf{1 1}$ has been reported to afford $\mathbf{1 2}$ in 40-70\% yields under thermal conditions and in $42-77 \%$ yields under microwave irradiation, ${ }^{27}$ while $\mathbf{1 3}$ produced $\mathbf{1 4}$ on reaction with hydrazine hydrate (Scheme 3 ). ${ }^{28}$

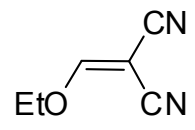

11<smiles>N#CC(C#N)=C1OCCO1</smiles>

13

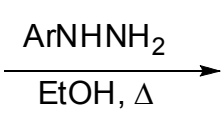

or $\mathrm{EtOH}, \mathrm{MW}$

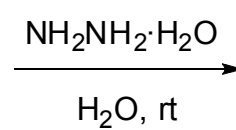

$\mathrm{H}_{2} \mathrm{O}, \mathrm{rt}$

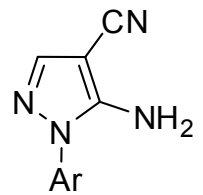

12

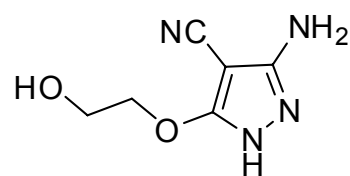

14

$\mathrm{Ar}=\mathrm{Ph}, 4-\mathrm{FC}_{6} \mathrm{H}_{4}, 2-\mathrm{ClC}_{6} \mathrm{H}_{4}, 2,4-\mathrm{F}_{2} \mathrm{C}_{6} \mathrm{H}_{3}, 4-\mathrm{MeOC}_{6} \mathrm{H}_{4}, 2,4-\mathrm{Me}_{2} \mathrm{C}_{6} \mathrm{H}_{3}, 3,5-\mathrm{Me}_{2} \mathrm{C}_{6} \mathrm{H}_{3}, 2,6-\mathrm{Cl}_{2}-4-\mathrm{CF}_{3} \mathrm{C}_{6} \mathrm{H}_{2}$

\section{Scheme 3}

Reacting $\mathbf{1 5}$ with hydrazine hydrate at $75{ }^{\circ} \mathrm{C}$ for $2 \mathrm{~h}$ afforded $\mathbf{1 6} .{ }^{29 \mathrm{a}}$ In old literature, ${ }^{29 \mathrm{~b}} \mathbf{1 7}$ was the only isolated product. Also 15 reacted with phenylhydrazine to yield 18 (Scheme 4 ). ${ }^{30}$

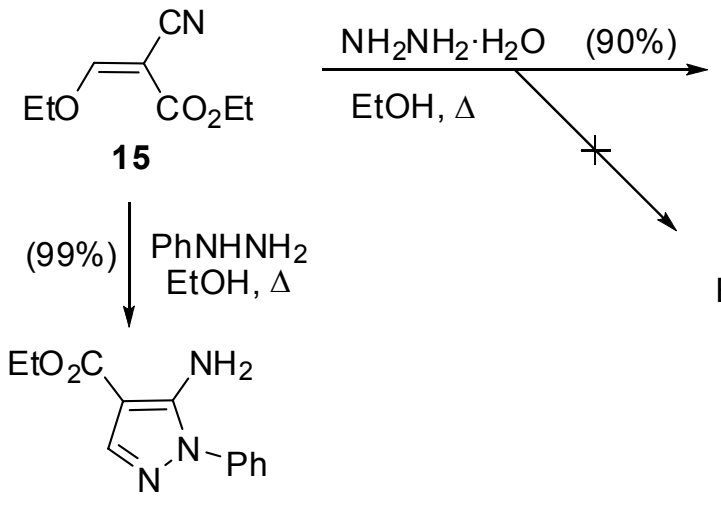

18

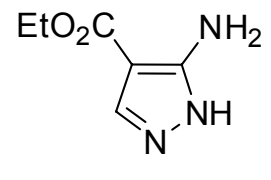

16<smiles>CCOC(=O)/C(C#N)=C/n1ncc(C(=O)OCC)c1N</smiles>

17

\section{Scheme 4}

2-Aroyl-3-(dimethylamino)acrylonitrile 19 has been reported to react with hydrazine hydrate to yield either $\mathbf{2 0}$ or $\mathbf{2 1}$ or a mixture of both depending on substitution pattern. ${ }^{31-33}$ When reacted with aminoguanidine nitrate, however, $19\left(\mathrm{R}=\right.$ 4-fluorophenyl) afforded only $\mathbf{2 0}$ in $62 \%$ yield. ${ }^{9}$ The reaction of $\mathbf{2 2}$ with hydrazine hydrate afforded the aminopyrolopyrazole $\mathbf{2 3}$ (Scheme 5). ${ }^{34}$ 
<smiles>[R]C(=O)/C(C#N)=C\N</smiles>

19<smiles>COC1=C(C#N)C(=O)NC1=O</smiles>

22<smiles>[R]C(=O)c1c[nH]nc1N</smiles>

20<smiles>[R]c1n[nH]cc1C#N</smiles>

21

$\mathrm{R}=\mathrm{Ph}, \mathrm{CHPh}_{2}, 2-\mathrm{MeOC}_{6} \mathrm{H}_{4}, 4-\mathrm{MeOC}_{6} \mathrm{H}_{4}$,<smiles>Nc1[nH]nc2c1C(=O)NC2=O</smiles>

$2-\mathrm{FC}_{6} \mathrm{H}_{4}, 2-\mathrm{ClC}_{6} \mathrm{H}_{4}, 4-\mathrm{ClC}_{6} \mathrm{H}_{4}, 2-\mathrm{O}_{2} \mathrm{NC}_{6} \mathrm{H}_{4}$, $3-\mathrm{O}_{2} \mathrm{NC}_{6} \mathrm{H}_{4}, 4-\mathrm{O}_{2} \mathrm{NC}_{6} \mathrm{H}_{4}, 4-\mathrm{CF}_{3} \mathrm{C}_{6} \mathrm{H}_{4}$,<smiles>Cc1cccs1</smiles>

23

\section{Scheme 5}

Treatment of diethyl 2,3-dicyanomaleate (24a) with arylhydrazines afforded 26a via cyclization of initially formed arylhydrazone derivative $\mathbf{2 5 a}{ }^{35}$ This was further extended to 5aminopyrazole-3,4-dicarbonitriles $\mathbf{2 6 b}$ from $\mathbf{2 4 b}$ and arylhydrazines (Scheme 6). ${ }^{36}$

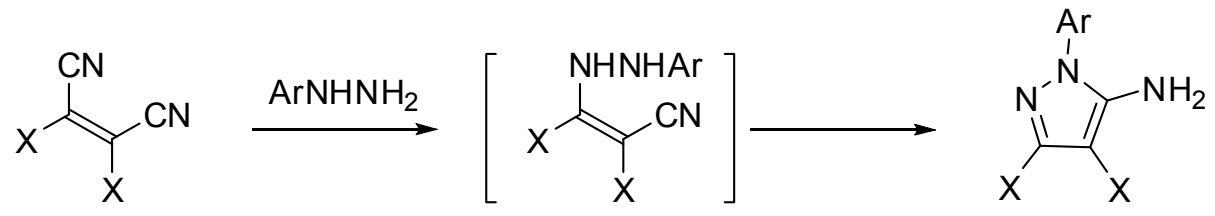

24a, $\mathrm{X}=\mathrm{CO}_{2} \mathrm{Et}$

b, $\mathrm{X}=\mathrm{CN}$

$25 a, b$

26a,b

$\mathrm{Ar}=4-\mathrm{FC}_{6} \mathrm{H}_{4}, 4-\mathrm{BrC}_{6} \mathrm{H}_{4}, 2,4-\mathrm{Cl}_{2} \mathrm{C}_{6} \mathrm{H}_{3}, 2,4,6-\mathrm{Cl}_{3} \mathrm{C}_{6} \mathrm{H}_{2}$

\section{Scheme 6}

A new synthesis of 5-aminopyrazoles on a solid support via in situ generation of resin bound aldehyde nitriles has been described. Thus, treatment of $\mathbf{2 7}$ with Bredereck's reagent afforded 28 that was hydrolysed in $2 \mathrm{~N} \mathrm{HCl}$ to yield 29. The latter reacted with hydrazines in the presence of organic acids in THF to yield $\mathbf{3 0}$ (Scheme 7). ${ }^{37}$ 
<smiles>[R1]NC(=O)c1ccc(CC#N)cc1</smiles>

27

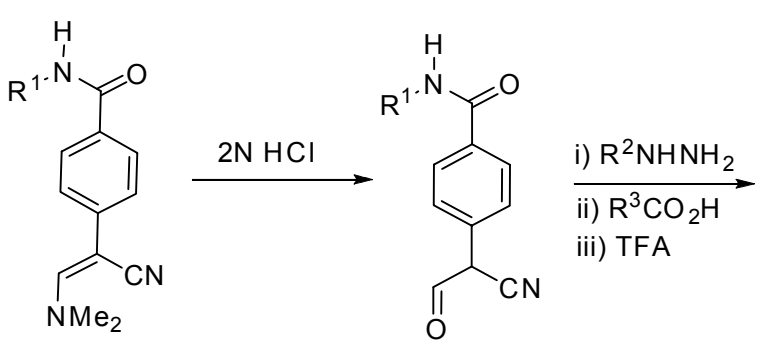

29

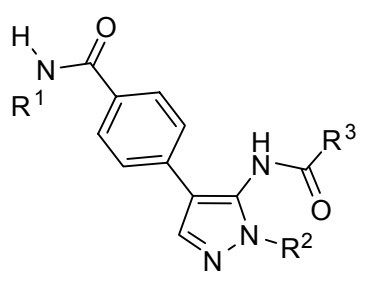

30

$\mathrm{R}^{1}=\operatorname{Resin}($ solid support)

$\mathrm{R}^{2}=4-\mathrm{MeOC}_{6} \mathrm{H}_{4}, 4-\mathrm{BrC}_{6} \mathrm{H}_{4}, \mathrm{CH}_{2} \mathrm{Ph}, n-\mathrm{Bu}$<smiles>[R]=C1C=CC=NC1</smiles>

\section{Scheme 7}

\subsection{Reactions of hydrazines with 3-oxo-alkanenitriles}

This is another general and efficient route to 3(5)-aminopyrazoles. Thus the reaction of $\mathbf{3 1}$ ( $\mathrm{X}=$ $\mathrm{COR}, \mathrm{CO}_{2} \mathrm{R}$ ) led to the formation of aminopyrazoles $\mathbf{3 2}$ and aminopyrazolone (33) (Scheme $8)^{38,39}$

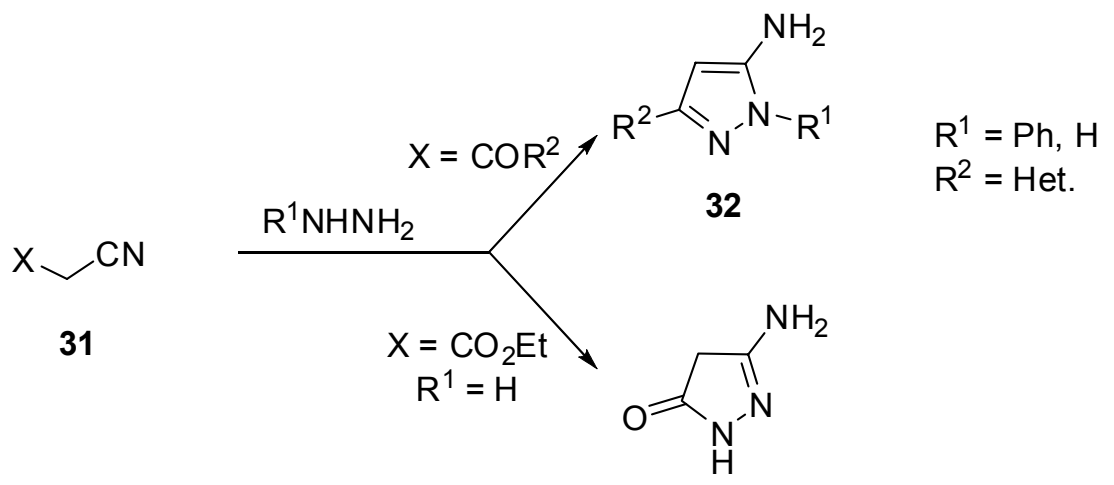

33

\section{Scheme 8}

Recently, compounds 35 and 37 were synthesized by the reaction of $\mathbf{3 4}$ and $\mathbf{3 6}$ with hydrazine hydrate (Scheme 9). ${ }^{40,41}$

The reaction of 3-oxoalkanenitriles with tosylhydrazines also gave 1-tosyl-3-substituted pyrazole amines that were deprotected by brief treatment with $\mathrm{NaOEt}$ in EtOH/DMSO at 45 ${ }^{\circ} \mathrm{C} .{ }^{42}$ 


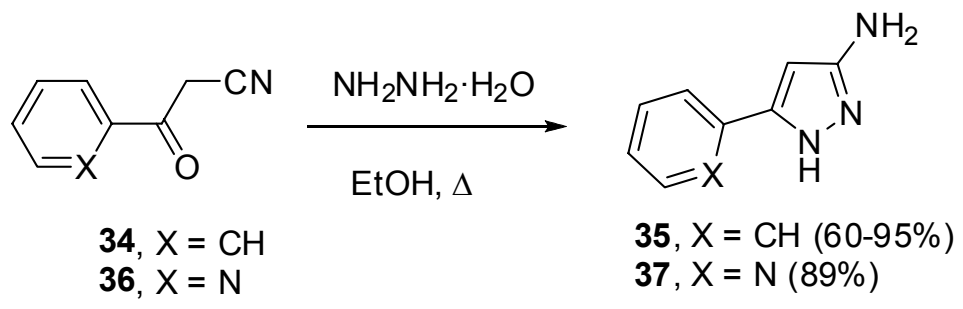

\section{Scheme 9}

Recently, heptanedinitrile (38) was condensed with ethyl formate in presence of sodium hydride and the soformed formyl derivative was then reacted with hydrazine hydrate to yield 39 (Scheme 10). ${ }^{43}$<smiles>N#CCCCCCCC#N</smiles>

38

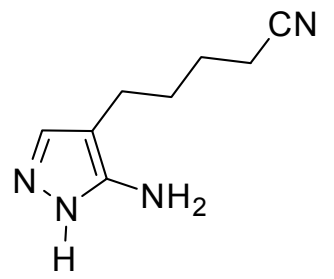

39

\section{Scheme 10}

The reaction of benzylcyanide (40) with triethylorthoformate and piperidine has been reported to yield $\mathbf{4 1}$ which reacted with hydrazine hydrate in a microwave oven to yield $\mathbf{4 2}$ (Scheme 11). ${ }^{44}$
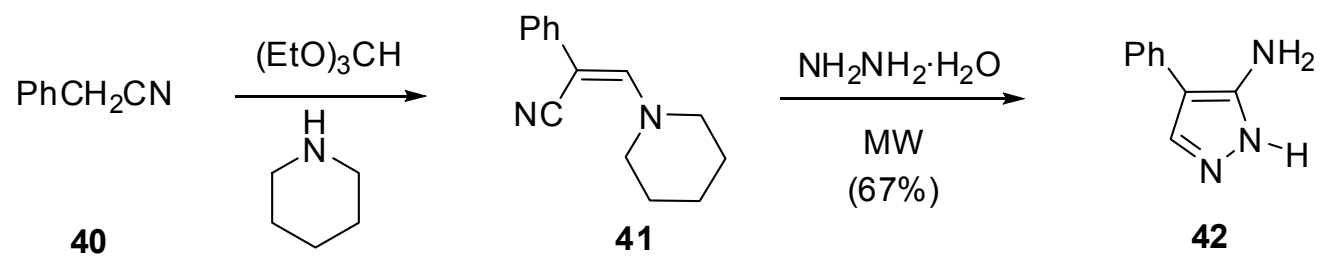

\section{Scheme 11}

4-Arylazopyrazol-5-amines 44 were generally prepared from the reaction of corresponding arylhydrazone $\mathbf{4 3}$ and hydrazines. These were extensively investigated as dyes and a variety of derivatives were thus prepared (Scheme 12). ${ }^{18,44,45}$ 
<smiles></smiles><smiles>[R]c1nn([R])c(N)c1N=N[Al]</smiles>

43 44

$\mathrm{R}^{1}=\mathrm{H}, \mathrm{Et}, \mathrm{Ph} ; \mathrm{R}^{2}=\mathrm{H}$, aryl; $\mathrm{Ar}=\mathrm{Ph}$, aryl

\section{Scheme 12}

Reacting 45 with hydrazine hydrochloride afforded 46 which was used as a drug intermediate (Scheme 13). ${ }^{46}$

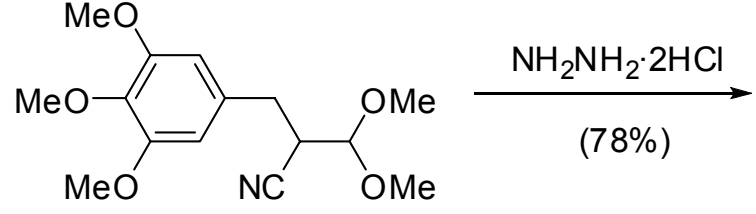

45<smiles>COc1cc(Cc2c[nH]nc2N)cc(OC)c1OC</smiles>

46

\section{Scheme 13}

\subsection{Synthesis from substituted hydrazones}

The reaction of hydrazonoyl halides 47 with active methylene nitriles is an established route to 3(5)-aminopyrazole. ${ }^{21}$ A recent example was reported in reaction of $\mathbf{4 7}$ with benzoylacetonitrile 48 to yield 49 (Scheme 14). ${ }^{47}$

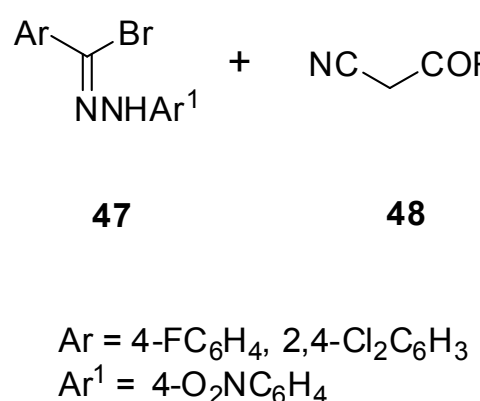

\section{Scheme 14}

An interesting synthesis of 3(5)-aminopyrazole derivatives 52 by a reaction of $\alpha$-haloketone hydrazones $\mathbf{5 0}$ and isocyanides $\mathbf{5 1}$ has been reported (Scheme 15). ${ }^{48}$ 


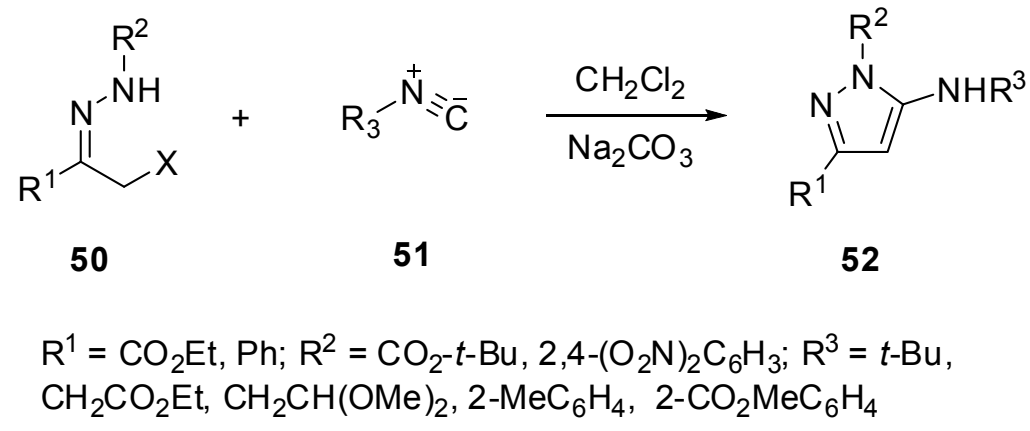

\section{Scheme 15}

An alternative to this approach was the cyclization of 55 which was believed to exist in equilibrium with 56 to yield 57. Compound 55 was produced by condensing 54 with $N$ cyanohydrazine $\mathbf{5 3}$ (Scheme 16). ${ }^{49}$

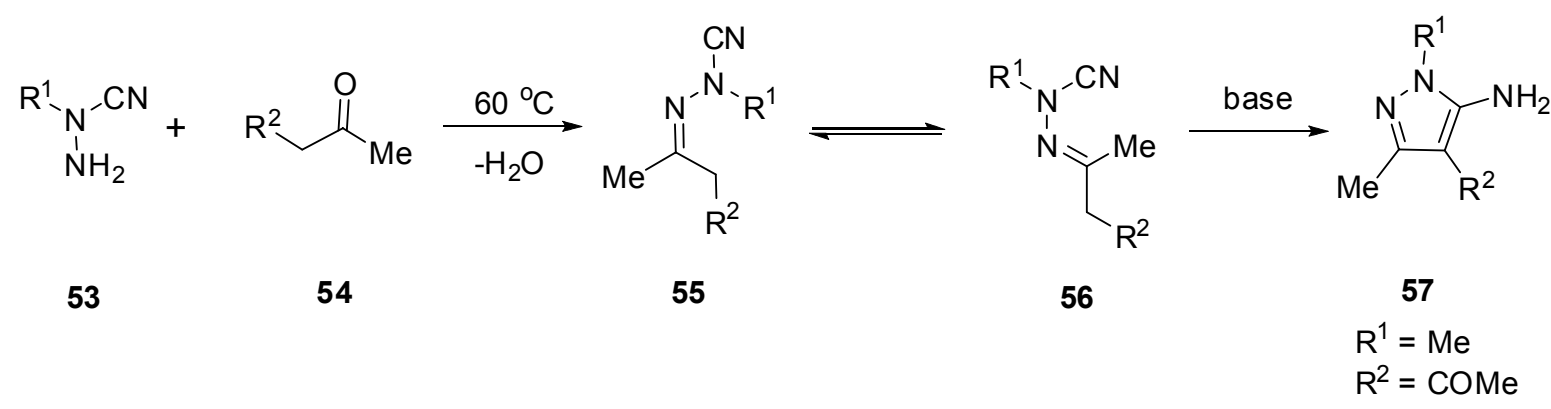

\section{Scheme 16}

\subsection{Miscellaneous syntheses}

The rearrangement of $\mathrm{N}$-aminopyrazole (58) in hydrobromic acid afforded 7 via intermediacy of 59 (Scheme 17). ${ }^{50}$

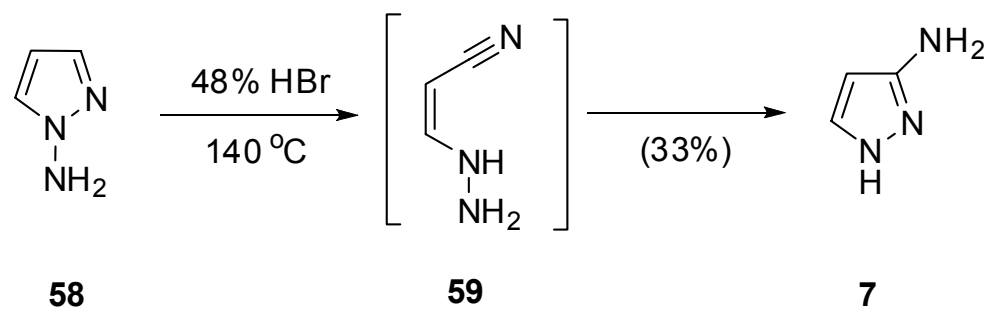

\section{Scheme 17}


It has been reported that 5-substituted aminopyrazoles 62 were formed via gently heating $\beta$ ketoamides 60 with aryl or alkylhydrazines and Lawesson's reagents (LR). Intermediacy of 61 is postulated (Scheme 18). ${ }^{51}$
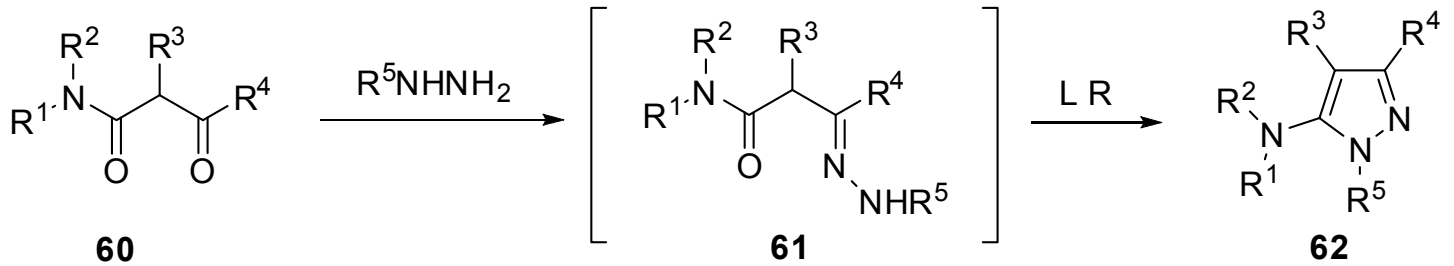

$R^{1}=E t, B n, P h ; R^{2}=H, M e, E t, B n ; R^{3}=H, M e, P h ; R^{4}=M e, P h ; R^{5}=B n, P h$

\section{Scheme 18}

\section{Synthesis of 4-Aminopyrazoles}

\subsection{Reduction of 4-nitroso, nitro and azopyrazoles}

The photosensitized reduction of 4-nitrosopyrazoles 63 using titanium dioxide as photocatalyst in the presence of triethylamine and acetonitrile afforded the corresponding 4-aminopyrazoles 64 (Scheme 19). ${ }^{52}$

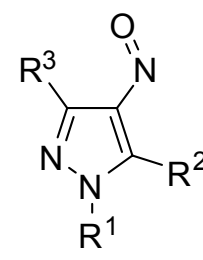

63
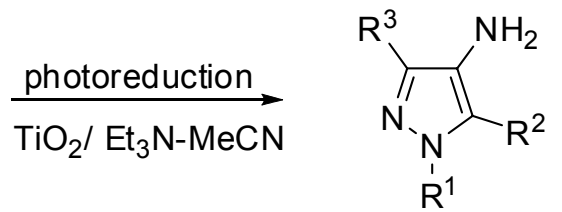

64

$$
\mathrm{R}^{1}=\mathrm{H}, \mathrm{Ph} ; \mathrm{R}^{2}=\mathrm{Me}, \mathrm{Ph} ; \mathrm{R}^{3}=\mathrm{Me}
$$

\section{Scheme 19}

3-Methyl-4-nitro-5-phenyl-1H-pyrazole (65) has been reduced using $\mathrm{Pd} / \mathrm{C}$ and $\mathrm{H}_{2}$ to yield corresponding aminopyrazole 66 (Scheme 20). ${ }^{53}$ 
<smiles>CCOCCCCCO</smiles>

65<smiles>Cc1n[nH]c(-c2ccccc2)c1N</smiles>

66

\section{Scheme 20}

4-Aminoantipyrine 67 was readily obtained via reduction of 4-nitroantipyrine 68 with $\mathrm{H}_{2}$ $\mathrm{Pd} / \mathrm{C}^{54}$ 4-Aminopyrazole carboxylic esters 71 were generally obtained via nitration of pyrazoles 69 and subsequent reduction of the nitro group to form $\mathbf{7 0}$ which were precursors of Viagra (Sildenafil) and its derivatives (Scheme 21). ${ }^{55,56}$

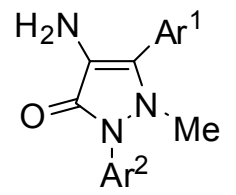

67

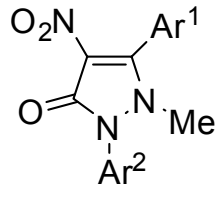

68

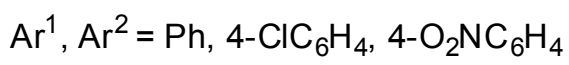<smiles>[R]c1[nH]nc(C(=O)OCC)c1[N+](=O)[O-]</smiles>

70

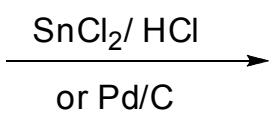<smiles>[R]c1[nH]nc(C(=O)OCC)c1N</smiles>

71

\section{Scheme 21}

Reductive cleavage of 4-arylazopyrazoles 72 with hydrazine hydrate has been claimed to afford 73 and 74 (Scheme 22). ${ }^{57}$

$\mathrm{R}$<smiles>[X]c1ccc(N=Nc2c(C)nn([Tl])c2C)cc1</smiles>

$\mathrm{R}=\mathrm{H}, \mathrm{Me}, \mathrm{CH}_{2} \mathrm{CHOH}, \mathrm{CH}_{2} \mathrm{CH}_{2} \mathrm{OAc}$, $\mathrm{Ph} ; \mathrm{X}=\mathrm{H}, \mathrm{CO}_{2} \mathrm{Et}$, Het.

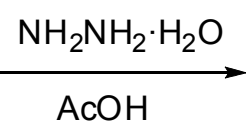

(27-80\%)<smiles>[R]n1nc(C)c(N)c1C</smiles>

73<smiles>[X]c1ccc(N)cc1</smiles>

74

\section{Scheme 22}




\subsection{Reaction of arylhydrazononitrile with functionally substituted alkylhalides}

This synthesis has recently been developed initially by Goncalves et al. ${ }^{58}$ who reported that mesoxalonitrile arylhydrazones 75a reacted with functionally substituted hydrazines in triethylamine solutions to yield 4-aminopyrazole-5-carbonitriles 77a. Subsequently, Elnagdi et $a l .{ }^{59-61}$ have extended this approach and could show that it is a general one of application for a variety of 2-arylhydrazononitriles 75b-d (Scheme 23). Elnagdi et al. have recently reviewed achievements in this direction. ${ }^{62}$

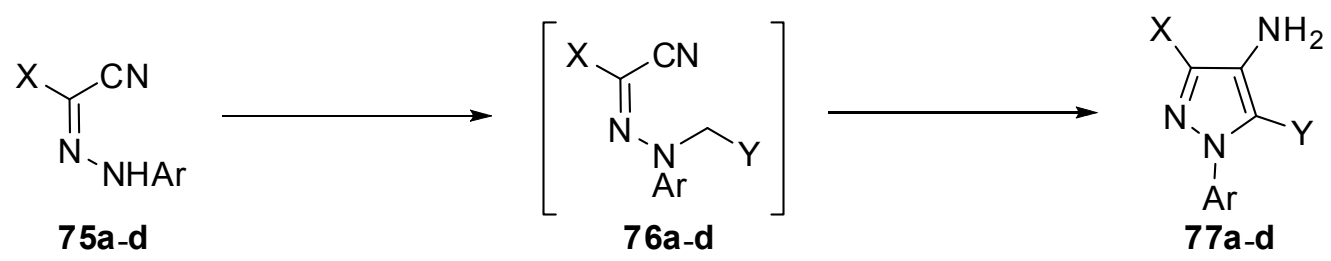

$$
\begin{aligned}
& \text { a, } X=\mathrm{CN} ; \mathbf{b}, \mathrm{X}=\mathrm{CO}_{2} \mathrm{Et} ; \\
& \text { c, } \mathrm{X}=\mathrm{COMe} ; \mathbf{d}, \mathrm{X}=\mathrm{CONH}_{2}
\end{aligned}
$$

\section{Scheme 23}

\subsection{Miscellaneous syntheses}

The reaction of ethyl diazoacetate (78) with arylacetonitriles afforded 4-aminopyrazole carboxylic esters 79. Similarly, the reaction of $\mathbf{7 8}$ with ethyl cyanoacetate gave $\mathbf{8 0}$ (Scheme 24). ${ }^{63}$<smiles>[X]c1n[nH]c(C(=O)OCC)c1N</smiles>

80 $\mathrm{X}=\mathrm{CO}_{2} \mathrm{Et}$

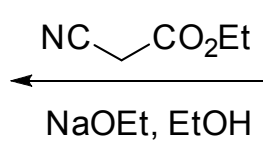

(1)

\section{Scheme 24}

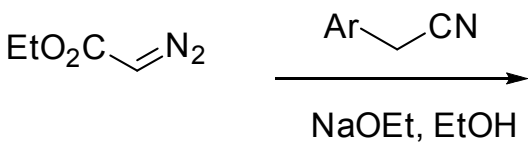

78<smiles>CCOC(=O)c1[nH]nc([Al])c1N</smiles>

79

A new method for the synthesis of substituted 4-amino-1-arylpyrazoles was described, starting from $\beta$-enaminones $\mathbf{8 1}$ and variously substituted benzenediazonium tetrafluoroborates to yield 82 under mild conditions. ${ }^{64 a}$ On the other hand, the addition of nitrilimines $\mathbf{8 3}$ to the benzoxazine 84 afforded 85 that underwent ring chain tautomerism and finally gave $\mathbf{8 6}^{64 \mathrm{~b}}$ (Scheme 25). 
<smiles>[R]C/C(N)=C/C([R])=O</smiles>

81

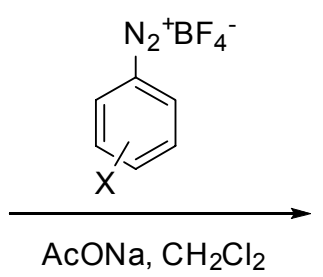

AcONa, $\mathrm{CH}_{2} \mathrm{Cl}_{2}$<smiles>[R]C(=O)c1nn(-c2cccc([X])c2)c([R])c1N</smiles>

82

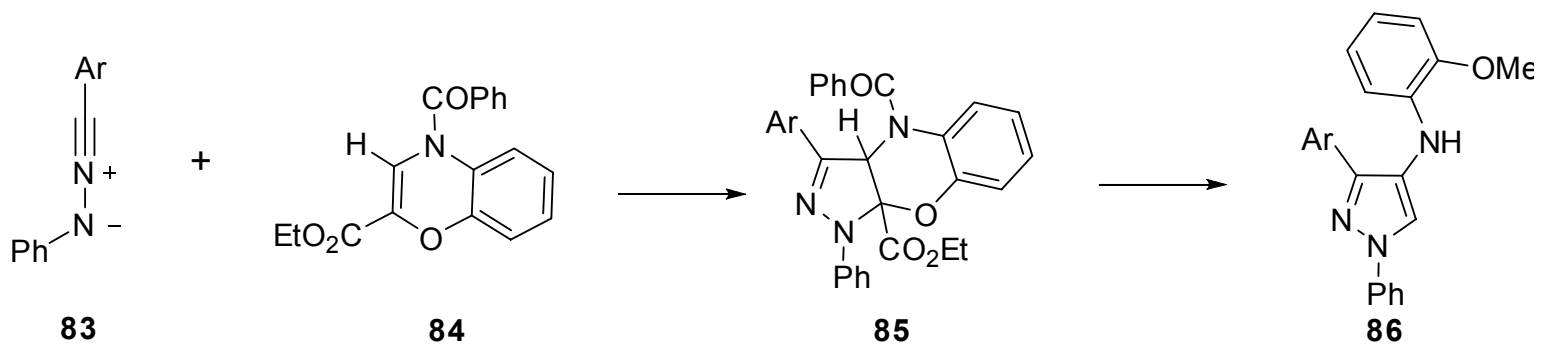

$\mathrm{R}^{1}=\mathrm{Et}, c-\mathrm{Pr}, \mathrm{Ph}$

$\mathrm{R}^{2}=\mathrm{Me}, \mathrm{Et}, \mathrm{Ph}$

$\mathrm{X}=$ 2-Me, 3-Me, 3- $\mathrm{CF}_{3}$, 3-CO $\mathrm{Ct}$, 4-Me, 4-OMe, 4-Cl

$\mathrm{Ar}=4-\mathrm{MeC}_{6} \mathrm{H}_{4}$

\section{Scheme 25}

The reaction of tetrazines $\mathbf{8 7}$ with cyanotrimethylsilane (TMSCN) gave the corresponding 4aminopyrazole derivatives $\mathbf{8 8}$ and $\mathbf{8 9}$ (Scheme 26). ${ }^{65}$<smiles>[R]c1nnc(P)nn1</smiles><smiles>CC(C)(C)C#N</smiles>

87<smiles>[R]C1=C(N)C([R])(C)N=N1</smiles>

88<smiles>[R]c1n[nH]c([R])c1N</smiles>

89

$$
\mathrm{R}=2-\mathrm{Py}, 4-\mathrm{Py}, \mathrm{CO}_{2} \mathrm{Me}
$$

\section{Scheme 26}

4-Aminopyrazoles were obtained via extention of Gabriel's synthesis of amino acids. Thus, reacting 90 with $\alpha$-bromoacetophenone gave 91 that condensed with dimethylforamide dimethyl acetyal (DMF-DMA) to yield 92. The latter reacted with hydrazine hydrate to yield $\mathbf{9 3}$ which was converted to 94 (Scheme 27). ${ }^{66,67}$ 
<smiles>O=C1NC(=O)c2ccccc21</smiles>

90<smiles>O=C(O)c1ccccc1</smiles>

$(90 \%)$

(1)<smiles>O=C(CN1C(=O)c2ccccc2C1=O)c1ccccc1</smiles>

91

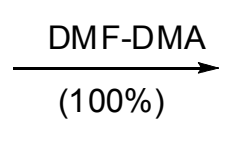<smiles>CN=C(C(=O)c1ccccc1)N1C(=O)c2ccccc2C1=O</smiles>

92

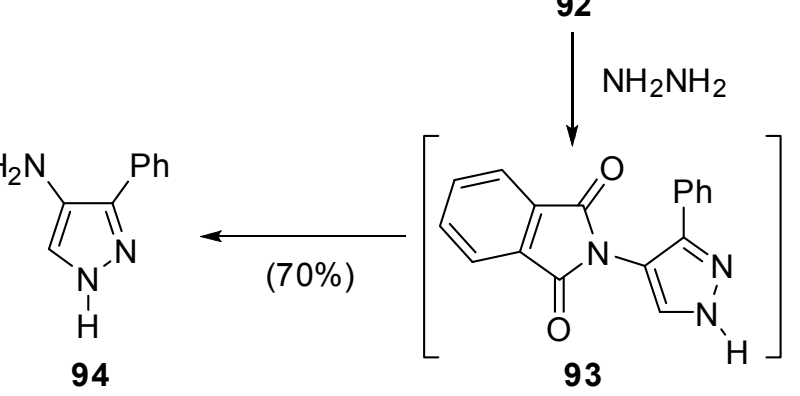

93

Scheme 27

\section{Synthesis of 1-aminopyrazoles}

These are obtained by $N$-amination of pyrazoles. Unsubstituted pyrazole (95) gave only $\mathbf{5 8}$ while substituted pyrazole 96 gave mixtures of $N-1$ and $N$-2-aminated products $97 \mathbf{a}$ and $97 \mathbf{b}$ (Scheme $28){ }^{68,69}$
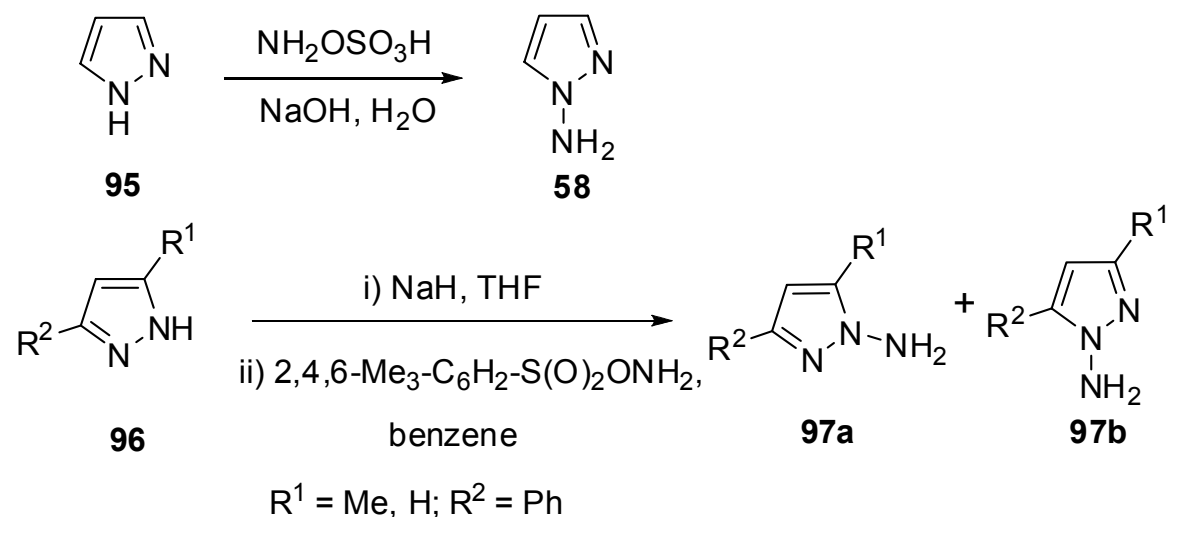

\section{Scheme 28}




\section{Synthesis of diaminopyrazoles}

\subsection{Synthesis of 3,5-diaminopyrazole and its derivatives}

It has been reported in old German literature ${ }^{70}$ that malononitrile (98) reacted with hydrazine hydrate to yield 3,5-diaminopyrazole 99. Subsequently Sato, ${ }^{71}$ Taylor, Hartke ${ }^{72}$ and Elnagdi and co-workers ${ }^{73}$ have established that the product was really 102; formed via initial dimerisation of malononitrile to yield 101. 3,5-Diaminopyrazole was subsequently prepared via reacting 100 with hydrazines $^{74 a}$ (Scheme 29).

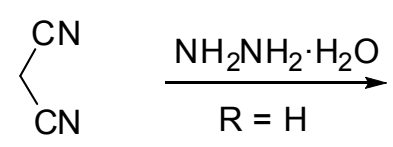

98<smiles>C/C=C(/N)CC#N</smiles>

101<smiles>[R]n1nc(N)cc1N</smiles><smiles>[R]C(C)=NN</smiles>

99<smiles>N#CCc1nn(-c2ccccc2)c(N)c1C#N</smiles>

102<smiles>CCOC(=N)CC(=N)OCC</smiles>

100

\section{Scheme 29}

Coupling malononitrile with aromatic diazonium salts afforded corresponding arylhydrazones $\mathbf{1 0 3}$ that reacted with hydrazine hydrate to yield arylazo-3,5-diaminopyrazoles 104. ${ }^{73 \mathrm{~b}}$ These compounds have been found interesting as formulation for hair dyes, antimicrobial agents and antitumor agents (Scheme 30). ${ }^{73 c, 74 b, c}$

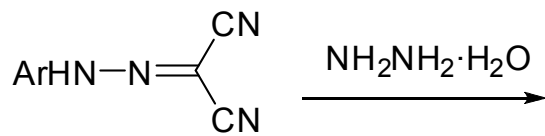

103<smiles>Nc1n[nH]c(N)c1N=[W]</smiles>

104

\section{Scheme 30}

Recently, Elnagdi et al. ${ }^{75}$ have successfully synthesized 4-benzylpyrazole-3,5-diamine (107) via reducing benzylidenemalononitrile (105) to 106 with sodium borohydride and reacting the latter with hydrazine hydrate to $\mathbf{1 0 7}$. Compound $\mathbf{1 0 7}$ has been previously obtained by Soto et 
al. ${ }^{76}$ via initially monoalkylating malononitrile (98) with $\mathbf{1 0 8}$ and subsequent reaction of 106 with hydrazine hydrate (Scheme 31).

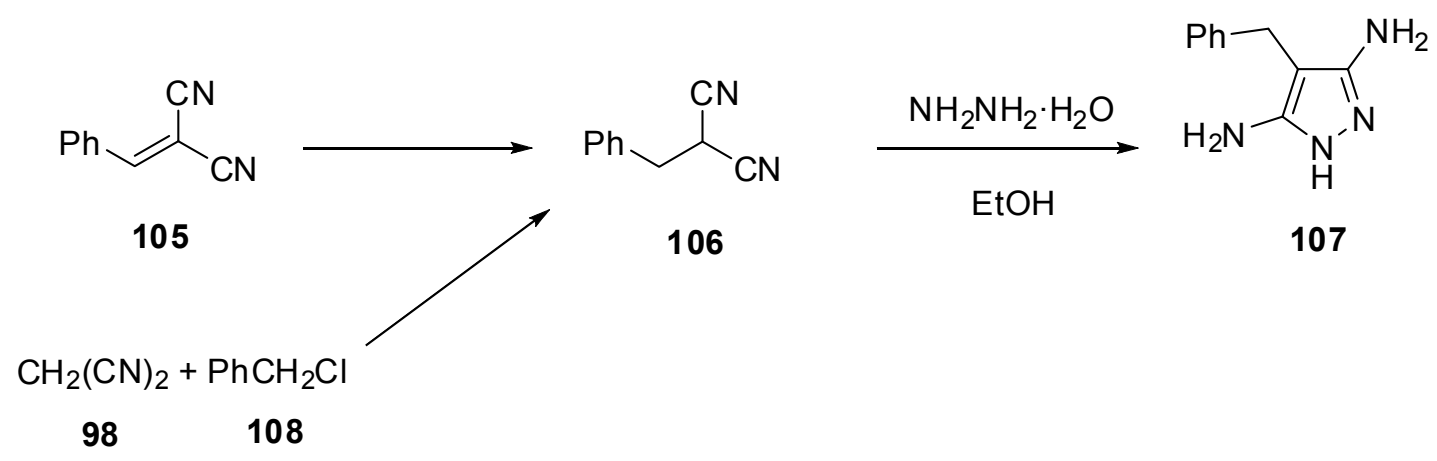

\section{Scheme 31}

The reaction of 3-(2-acylhydrazino)-3-aminopropenenitrile 109 with phenylisocyanate afforded a mixture of 110 and 111 (Scheme 32). ${ }^{77}$

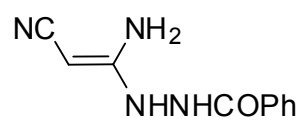

109

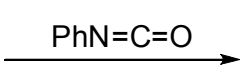

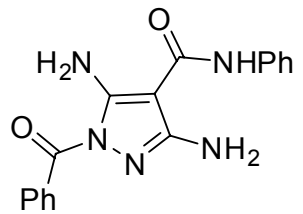

111

\section{Scheme 32}

Phenacylmalononitrile (112) has been reported by Abdelrazek et al. ${ }^{78 a}$ to react with hydrazinehydrate to yield 4-phenacylpyrazole-3,5-diamine (113) as sole product. Abdelrazek ${ }^{78 b}$ claimed utility for synthesis of a variety of condensed aminopyrazoles. Elnagdi et al. ${ }^{79}$ have subsequently noted isolation of the pyridazine-6-one (114a) as well as $\mathbf{1 1 3}$ on reacting 112 with

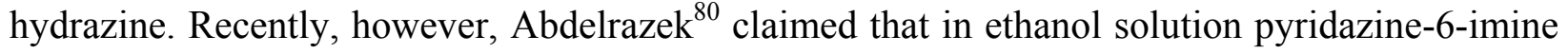
(114b) as well as the pyrazolo[3,4-c]pyridazine are formed in this same reaction. Recently, AlMousawi, Meier, Elnagdi and others ${ }^{81}$ have looked into these conflicting findings and have concluded that in ethanol at room temperature 114a is the sole isolable product in $90 \%$ yield. They could not detect any presence of 114b and it is believed that if it was formed it should hydrolyze directly to 114a. Upon refluxing 114a with excess hydrazine or when 112 was refluxed with excess hydrazine 115 was produced. Al-Mousawi et al. ${ }^{81}$ conclusions were supported by spectroscopic data (Scheme 33). 


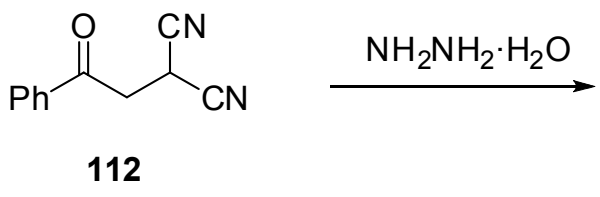<smiles>Nc1n[nH]c(N)c1CC(=O)c1ccccc1</smiles>

113<smiles>N#CC1CC(c2ccccc2)=NN(c2ccccc2)C1=N</smiles>

114b<smiles>N#CC1CC(c2ccccc2)=NNC1=O</smiles><smiles>NC1=NNC2NN=C(c3ccccc3)CC12</smiles>

\section{Scheme 33}

\subsection{Synthesis of 4,5-diaminopyrazoles}

4,5-Diaminopyrazole derivatives 117 were obtained via nitrosation and reduction of 5aminopyrazole derivatives 32 under mild conditions (Scheme 34). ${ }^{82}$

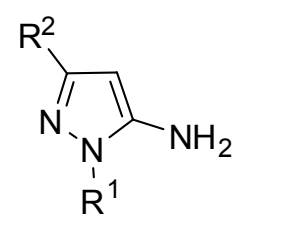

32

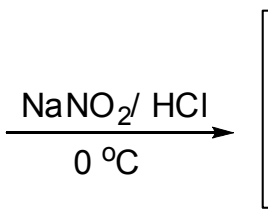<smiles>[R]c1nn([R1])c(N)c1[N+](=O)[O-]</smiles>

116<smiles>[R]c1nn([R1])c(N)c1N</smiles>

117

$$
\mathrm{R}^{1}=\mathrm{Me}, \mathrm{Ph}, p \text {-Tolyl; } \mathrm{R}^{2}=\mathrm{Me}, t-\mathrm{Bu}, \mathrm{Ph}
$$

\section{Scheme 34}

1-Substituted 5-aminopyrazole-4-carbonylazines 118 were prepared from appropriate 5aminopyrazole-4-carboxylates. The acyl azides undergo a Curtius rearrangement followed by quenching with alcohols to form the corresponding carbamates 119. The 1-substituted 5-amino4-benzyloxycarbonylaminopyrazoles 119 were unblocked by catalytic hydrogenolysis to give 4,5-diaminopyrazolones 120. These 4,5-diaminopyrazoles were directly condensed with glyoxal to afford 1-substituted pyrazolo[3,4-b]pyrazines 121 (Scheme 35). ${ }^{83}$ 


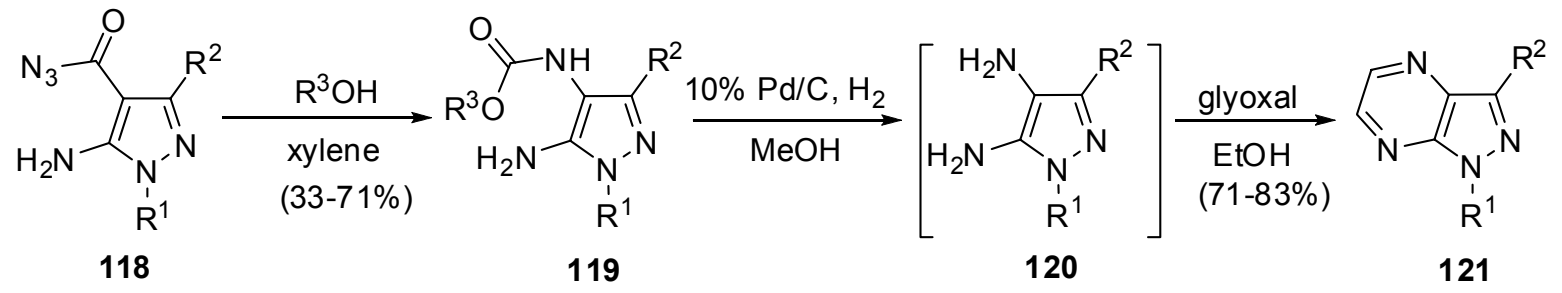

$\mathrm{R}^{1}=\mathrm{Ph}, \mathrm{Bn} ; \mathrm{R}^{2}=\mathrm{H}, \mathrm{Me} ; \mathrm{R}^{3}=\mathrm{Et}, \mathrm{Bn}$

Scheme 35

\section{Chemical reactivity of aminopyrazoles}

\subsection{3(5)-Aminopyrazoles}

6.1.1. Reactions with electrophilic reagents. Over the years, numerous investigations on reactivity of monoelectrophiles and polydentate electrophiles toward pyrazol-5-amines have been reported. In fact, there are four sites for electrophile attack in 7 whereas three such sites are available for their reaction with 32 (Figure 2).
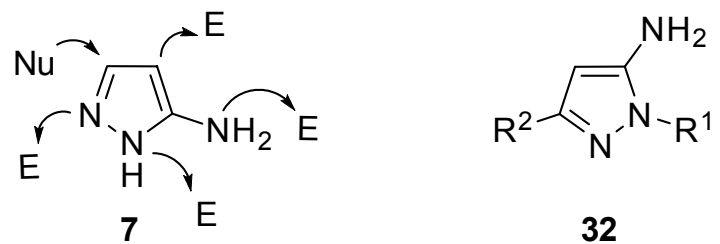

$$
\mathrm{R}^{1}, \mathrm{R}^{2}=\text { alkyl, aryl, halogen, etc. }
$$

Figure 2. Sites of electrophilic attack in the 3(5)-aminopyrazole.

The nature of the end products in electrophilic substitution reactions seems to depend on the type of the reagent and reaction conditions.

6.1.2. Diazotizations. These reactions occur either at exocyclic amine or at $\mathrm{C}-4$ because under these conditions the ring nitrogen, which is the most nucleophilic moiety, is protonated.

Thus, 3(5)-aminopyrazole 122 has been diazotized in acetic acid with $\mathrm{HCl}$ and sodium nitrite to yield pyrazoldiazonium salts $\mathbf{1 2 3}$. These have been coupled with a variety of active methylene reagents like malononitrile and ethyl cyanoacetate $(\mathbf{1 2 4 a}, \mathbf{b})$ to yield pyrazol-5-ylhydrazones $\mathbf{1 2 5 a}, \mathbf{b}$ that were readily cyclized into pyrazolo[5,1-c]-1,2,4-triazines $\mathbf{1 2 6} \mathbf{a}, \mathbf{b} .{ }^{19}$ On the other hand, attempted coupling with benzoylacetonitrile (127), enaminonitriles 129, enaminones 131, 3-aminocrotononitrile (133), ethyl acetoacetate and acetylacetone (135a,b) resulted in direct formation of pyrazolo[5,1-c]1,2,4-triazines 128, 130, 132, 134, and 136a,b, respectively via 
cyclocondensation reaction which took place under coupling reaction conditions. ${ }^{84,85} \beta$-Naphthol reacted in the same way. ${ }^{84,86} \alpha$-Chloroacetylacetone $\mathbf{1 3 7}$ as well as ethyl $\alpha$-chloroacetoacetate afforded also heterocyclic hydrazidic halides 138 via a Japp-Klingemann acyl group cleavage (Scheme 36). ${ }^{87}$<smiles>[R]Cc1nnc2c([R])c([R])nn2c1[Y16]</smiles><smiles>[R]c1nn2c([14CH3])c(C#N)nnc2c1[R]</smiles><smiles>[R]C(=O)CC(C)=O</smiles>

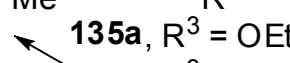<smiles>C=[Ru]C</smiles><smiles>[R]C1=N[NH2+]C(N)=C1[R]</smiles>
$\mathrm{NaNO}_{2} / \mathrm{HCl}$<smiles>[R]C(=O)c1cn2nc([R])c([R])c2nn1</smiles>

132

$\mathrm{R}^{3}=$ alkyl, aryl, Het.

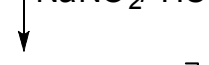<smiles>[R]c1n[nH]c([N+]=[N-])c1C</smiles>

123<smiles>C/C=C(\[14CH3])N</smiles>

$\mathrm{R}^{1}, \mathrm{R}^{2}=\mathrm{H}$, alkyl, aryl<smiles>CC(=O)C(Cl)C(C)=O</smiles><smiles>C=CC</smiles><smiles>[X]/C(CN)=N\Nc1[nH]nc([R])c1[R]</smiles>

125a, $X=C N$

b, $\mathrm{X}=\mathrm{CO}_{2} \mathrm{Et}$<smiles>[X]C[14CH2][14CH2][14CH2]</smiles>
$124 a, b$<smiles>CC1CC1</smiles><smiles>[R]c1nn2c(N)c([X])nnc2c1[R]</smiles>

126a, $X=C N$

b, $\mathrm{X}=\mathrm{CO}_{2} \mathrm{Et}$

\section{Scheme 36}

$3 H$-pyrazolo[5,1-c][1,2,4]triazoles $\mathbf{1 3 9}$ were obtained from diazotized $\mathbf{1 2 2}$ and diphenyldiazomethane in $28-78 \%$ yield (Scheme 37$){ }^{88}$<smiles>[R]c1n[nH]c(N)c1[R]</smiles>

122

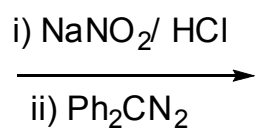

$\mathrm{R}^{1}=\mathrm{Me} ; \mathrm{R}^{2}=\mathrm{Ph}$<smiles>[R]c1nn2c(c1[R])N=NC2(c1ccccc1)c1ccccc1</smiles>

139

\section{Scheme 37}


Reactivity of aminopyrazoles in diazotization and coupling was discussed in a recent report and the pattern demonstrated previously was confirmed. ${ }^{89}$

Moyano et al. have reported the isolation of pyrazolotriazines 141 and 145 on diazotization of 140 (Scheme 38). ${ }^{89}$<smiles>[R]c1nn([R10])c(N)c1C#N</smiles>

$\downarrow \begin{aligned} & \mathrm{NaNO}_{2} / \mathrm{HCl} \\ & \mathrm{R}^{1}=\mathrm{Ph} ; \mathrm{R}^{2}=\mathrm{H}\end{aligned}$

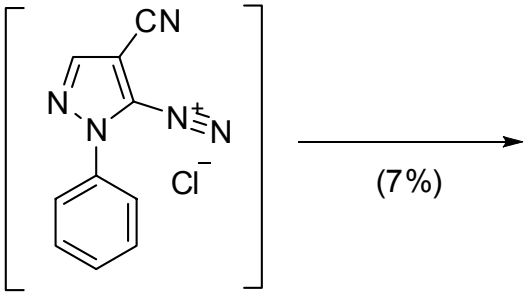

144<smiles>[R]c1nn([R1])c2nn[nH]c(=O)c12</smiles>

141

$(47-77 \%)$<smiles>[R]c1nn([R1])c(C)c1C#N</smiles>

142

$(1-8 \%)$<smiles>[R]c1nn([R1])cc1C#N</smiles>

143

$(1 \%)$<smiles>N#Cc1cnn2c1nnc1ccccc12</smiles>

145

\section{Scheme 38}

Diazotization of 146 afforded diazonium derivative 147 that readily cyclized into 148 . Similarly, diazotization of 149 gave $\mathbf{1 5 0}$ (Scheme 39). ${ }^{90,91}$

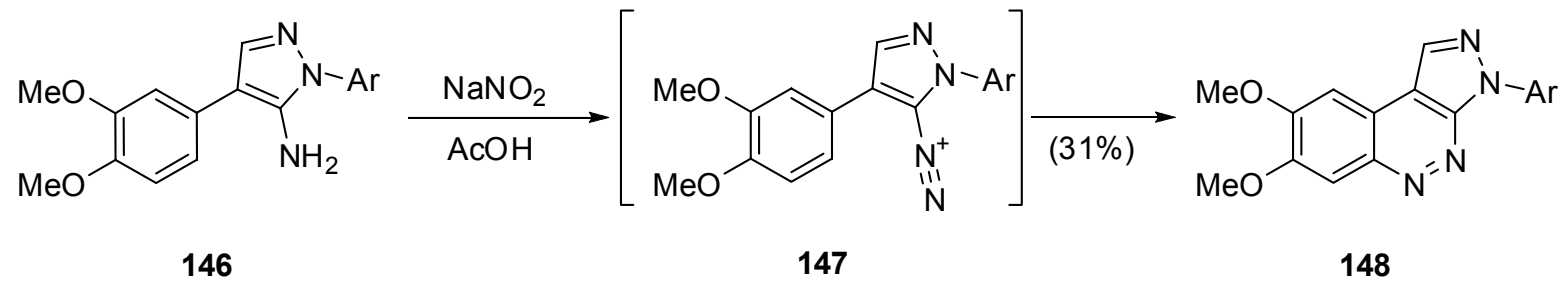

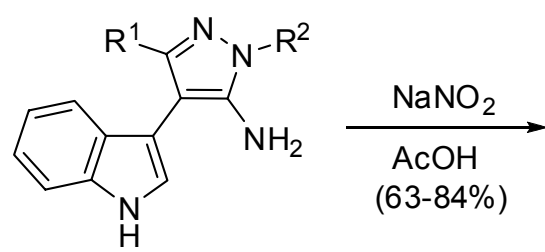

149<smiles>[R]c1nn([R])c2nnc3[nH]c4ccccc4c3c12</smiles>

150<smiles>Clc1cn[14c]([141I])[14c](Cl)c1</smiles>

$R^{1}=M e, P h ; R^{2}=H, P h$

Scheme 39 
Diazotization of 151 gave diazo-3(methylsulfonyl)-1H-pyrazole 152 that reacted with aryl isocyanates in dichloromethane to give $\mathbf{1 5 3}$ (Scheme 40). ${ }^{92}$<smiles>CCOC(=O)c1c(S(C)(=O)=O)n[nH]c1N</smiles>

151

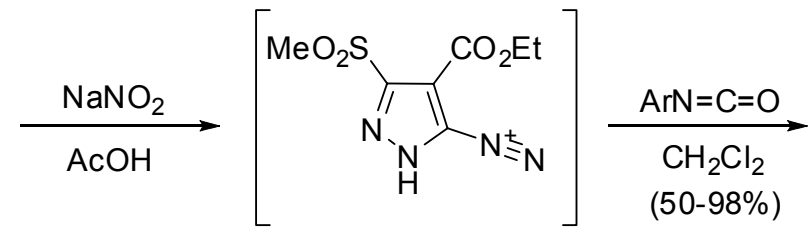

152<smiles>CCOCc1c(SOC)nn2c(=O)n([Al])nnc12</smiles>

153

$\mathrm{Ar}=\mathrm{Ph}, 4-\mathrm{FC}_{6} \mathrm{H}_{4}, 2-\mathrm{FC}_{6} \mathrm{H}_{4}, 3-\mathrm{ClC}_{6} \mathrm{H}_{4}, 4-\mathrm{ClC}_{6} \mathrm{H}_{4}, 2,4-\mathrm{Cl}_{2} \mathrm{C}_{6} \mathrm{H}_{3}$, $4-\mathrm{CNC}_{6} \mathrm{H}_{4}, 4-\mathrm{O}_{2} \mathrm{NC}_{6} \mathrm{H}_{4}, 2-\mathrm{O}_{2} \mathrm{NC}_{6} \mathrm{H}_{4}, 2-\mathrm{CF}_{3} \mathrm{C}_{6} \mathrm{H}_{4}, 4-\mathrm{EtO}_{2} \mathrm{CC}_{6} \mathrm{H}_{4}$

\section{Scheme 40}

Neutralization of diazotized pyrazolamines afforded diazonium betain that has been reported to add vinyl ethers, acetylenes and isocyanates. ${ }^{93}$

Diazotization of 3-amino-1-phenylpyrazole (154) gave the corresponding diazonium salt 155 that reacted with 156 to yield 157 that was readily cyclized into 158 (Scheme 41). ${ }^{94}$

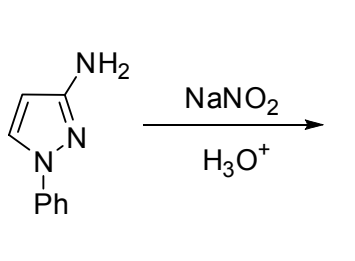

154

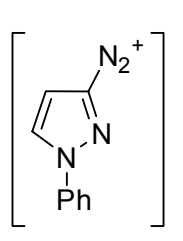

155

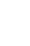

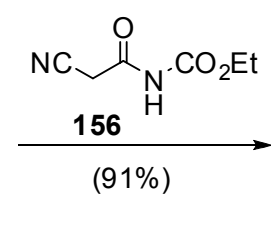

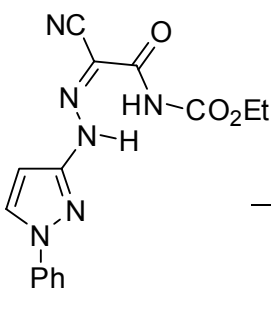

157<smiles>N#Cc1nn(-c2ccn(-c3ccccc3)n2)c(=O)[nH]c1=O</smiles>

158

\section{Scheme 41}

Diazotization of 159 afforded the corresponding diazonium chloride 160 that underwent $6 \pi$ electrocyclization yielding pyrazolo[3,4-c]pyridazine 161 (Scheme 42). ${ }^{95}$

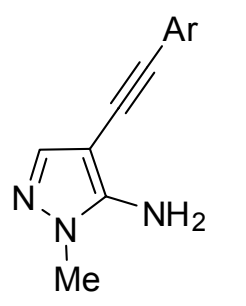

159

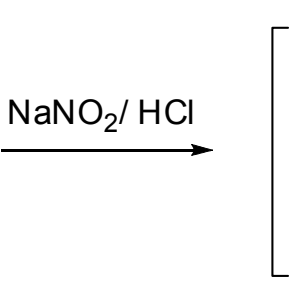

$\mathrm{NaHCO}_{3}$ $\mathrm{Ar}=\mathrm{Ph}(91 \%) ;$ $4-\mathrm{MeOC}_{6} \mathrm{H}_{4}$ (84\%)<smiles>Cn1ncc2c(O)c(Br)nnc21</smiles>

161

\section{Scheme 42}


Attempted diazotization of $\mathbf{1 6 2}$ led to the formation of 4-nitroso derivative $\mathbf{1 6 3}$ (Scheme $43) .^{96}$

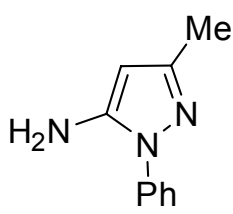

162

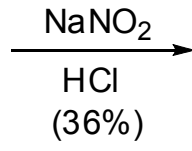

$(36 \%)$<smiles>Cc1nn(-c2ccccc2)c(N)c1N=O</smiles>

163

\section{Scheme 43}

6.1.3. Halogenation. Direct halogenation of 1,3-disubstituted 5-amino-pyrazoles 164 by halogen in acetic acid or $\mathrm{N}$-chlorosuccinimide in acetonitrile afforded 4-halo-pyrazol-5-amines 165 (Scheme 44). ${ }^{97 a-c}$

A novel green iodination of 3-aminopyrazole was described with iodine and hydrogen peroxide in water to give 4 -iodo-3-aminopyrazole in $82 \%$ yield. ${ }^{97 \mathrm{~d}}$

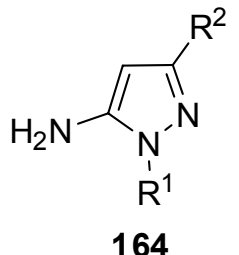

164

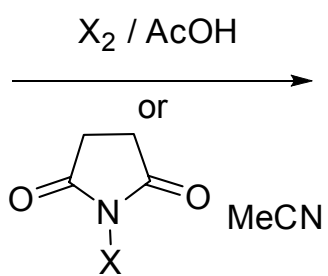

$\mathrm{R}^{1}, \mathrm{R}^{2}=\mathrm{H}$, alkyl, aryl; $\mathrm{X}=\mathrm{Cl}, \mathrm{Br}$

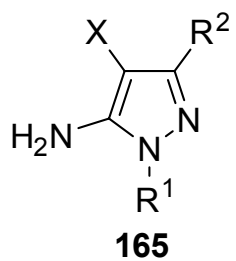

165

\section{Scheme 44}

Treatment of $\mathbf{1 6 6}$ with bromine water gave azo dyes resulting from dimerization through the amino groups, which was reduced to starting 167 by with zinc in acetic acid (Scheme 45). ${ }^{98}$<smiles>Cc1ccc(-n2ncc(C#N)c2N)cc1</smiles>

166

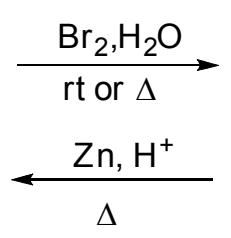<smiles>Cc1ccc(-n2ncc(C#N)c2/N=N/c2c(C#N)cnn2-c2ccc(C)cc2)cc1</smiles>

167

\section{Scheme 45}


6.1.4. Acylation. Acylation of $\mathbf{1 6 8}$ afforded a mixture of the 3(5)-acylaminopyrazole $\mathbf{1 6 9}$ as well as the acylpyrazoles $\mathbf{1 7 0}$ and 171 (Scheme 46). ${ }^{26,99}$ Acylation using various reagents may be restricted to the $5-\mathrm{NH}_{2}$ group, ${ }^{100}$ especially when position 5 is blocked (Scheme 47). ${ }^{101,102}$<smiles>[R]c1cc(N)[nH]n1</smiles>

\section{Scheme 46}<smiles>CCOC(=O)c1c(C)nn(C)c1N</smiles>

172<smiles>[R]c1cc(N)n(-c2ccccc2)n1</smiles>

175<smiles>Nc1ccn[nH]1</smiles>

7<smiles>COC(=O)Cc1ccc(OC)cc1</smiles>

173<smiles>CC(=O)c1ccc(S(=O)(=O)OCc2ccccc2)cc1</smiles>

176<smiles>O=C(Oc1ccccc1)c1ccccc1O</smiles><smiles>[CH]1CC1</smiles>

178<smiles>CCOC(=O)c1c(C)nn(N(C)C)c1NC(=O)Cc1ccc(OC)cc1</smiles>

174<smiles>CC(=O)c1ccc(S(=O)(=O)Nc2cc(C)nn2-c2ccccc2)cc1</smiles>

179

\section{Scheme 47}

Attempted acylation of 1,3-disubstituted-5-pyrazolamines (32) by acetic anhydride in the presence of sulfuric acid afforded 181, most likely via intermediacy of $\mathbf{1 8 0}$ (Scheme 48). ${ }^{103}$ 


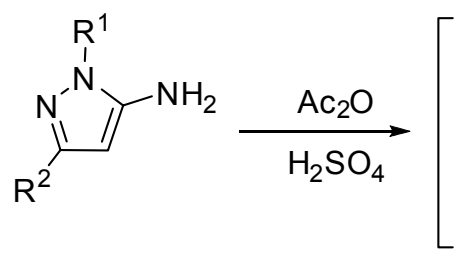

32
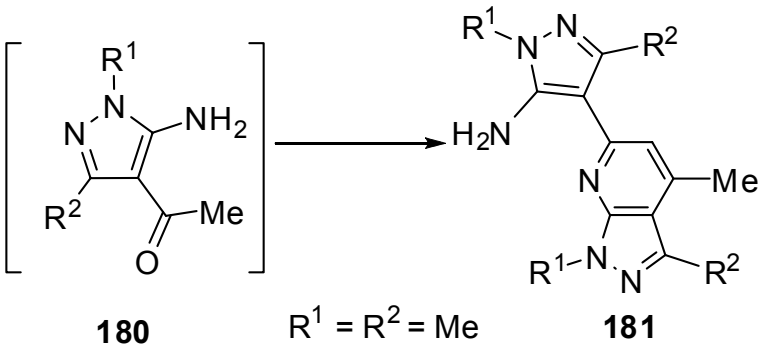

181

\section{Scheme 48}

Isocyanates and isothiocyanates, respectively, reacted with aminopyrazoles 168 yielding the corresponding urea 182a and the thiourea 182b (Scheme 49). ${ }^{104,105}$

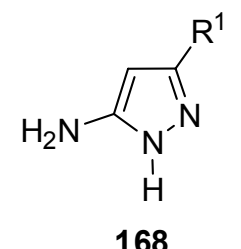

168

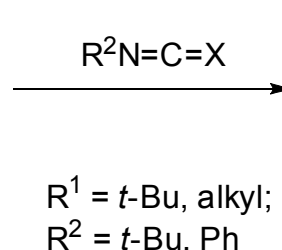

$\mathrm{R}^{2}=t-\mathrm{Bu}, \mathrm{Ph}$

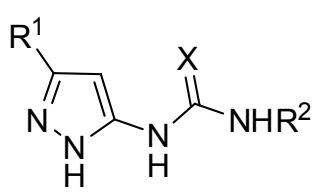

$182 a(X=O)$ $182 b(X=S)$

\section{Scheme 49}

Treatment of commercially available ethyl 5-amino-1-methylpyrazole-4-carboxylate (183) by rac-2-(phthalylamino)isovaleryl chloride (184) under thermal conditions in toluene in the presence of $i$ - $\operatorname{Pr}_{2} \mathrm{NEt}$ afforded 185 in high yield (89\%). The latter could be cyclized into 186 upon treatment with hexachloroethane and triphenylphosphine in dichloromethane. Treatment of 185 with the same reagents in the presence of $\mathrm{EtNH}_{2}$ gave 187in $71 \%$ yield. The latter could readily be cyclized into $\mathbf{1 8 8}$ in $65 \%$ yield (Scheme 50). ${ }^{106}$ 
<smiles>CCOC(=O)c1cnn(C)c1N</smiles>

183

(89\%)<smiles>CCOC(=O)c1cnn(C)c1NC(=O)C(C(C)C)C(c1ccccc1)c1ccccc1</smiles>

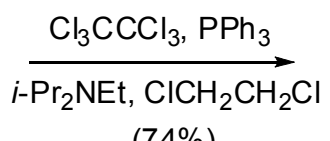

(74\%)<smiles>CC(C)C(c1nc2c(cnn2C)c(=O)o1)C(Nc1ccccc1)C(C)(C)C</smiles><smiles>[NH2+][NH+]=CN1C(=O)c2ccccc2C1=O</smiles>
(71\%) $\mathrm{Cl}_{3} \mathrm{CCCl}_{3}, \mathrm{PPh}_{3}$, $i-\mathrm{Pr}_{2} \mathrm{NEt}, \mathrm{CH}_{2} \mathrm{Cl}_{2}$,
$\mathrm{EtNH}$ $\checkmark$<smiles>CCNC(=Nc1c(C(=O)OCC)cnn1C)C(Nc1ccccc1)C(C)C(C)C(=O)OF</smiles>

187<smiles>CCn1c(C([PH+]c2ccccc2)C(C)C)nc2c(cnn2C)c1=O</smiles>

188

\section{Scheme 50}

6.1.5. Reactivity toward bidentate electrophiles. Reactions of this type have been extensively utilized as a route to the synthesis of biologically interesting pyrazolo[1,5-a]pyrimidines as well as pyrazolo[3,4- $b]$ pyridines. Unraveling site selectivity in these additions is not an easy task unless an acyclic intermediate can be isolated or the same reaction products can be synthesized by alternate routes. In several cases, modern NMR techniques studies were used to corroborate the structures of reaction products.

Elnagdi et al. have established that cyanoethylation of 189 occurred at $N-1$ and the reaction products 190 could be also prepared via reacting 192 with $1-\beta$-cyanoethylhydrazine 191. This cyanoethylation product could be subsequently cyclized into 194. Compound 194 was obtained by reacting 189 with ethyl acrylate and subsequent cyclization of the formed $\mathbf{1 9 3}^{18}$ (Scheme 51).<smiles>[R]c1c(-c2ccccc2)n[nH]c1N</smiles>

189<smiles>C/C=C\C(=O)OCC</smiles><smiles>[R]c1c(-c2ccccc2)nn(CCOC(=O)CC)c1N</smiles>

$\mathrm{R}^{1}=\mathrm{H}, \mathrm{N}=\mathrm{NAr}$

193

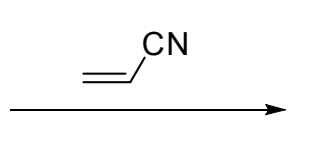<smiles>[R]c1c(-c2ccccc2)nn(CCC#N)c1N</smiles>

190<smiles>[R]c1c(-c2ccccc2)nn2c1NC(=O)CC2</smiles><smiles>N#CCC[18N]N</smiles><smiles>[R]C(C#N)C(=O)c1ccccc1</smiles>

192

\section{Scheme 51}


The reaction of $\mathbf{1 2 2}$ with arylidenemalononitrile has been initially reported to yield $\mathbf{1 9 5} .^{8 \mathrm{~g}, 107}$ However, recently it was shown that reactions of this type yielded 196. Single crystal X-ray structure analysis and $\mathrm{HMBC}-{ }^{15} \mathrm{~N}$ were successfully utilized to establish the structure. ${ }^{44}$ Many examples of this reaction have been reported and in some cases the single crystal X-ray structure analysis was reported (Scheme 52). ${ }^{61,108-110}$

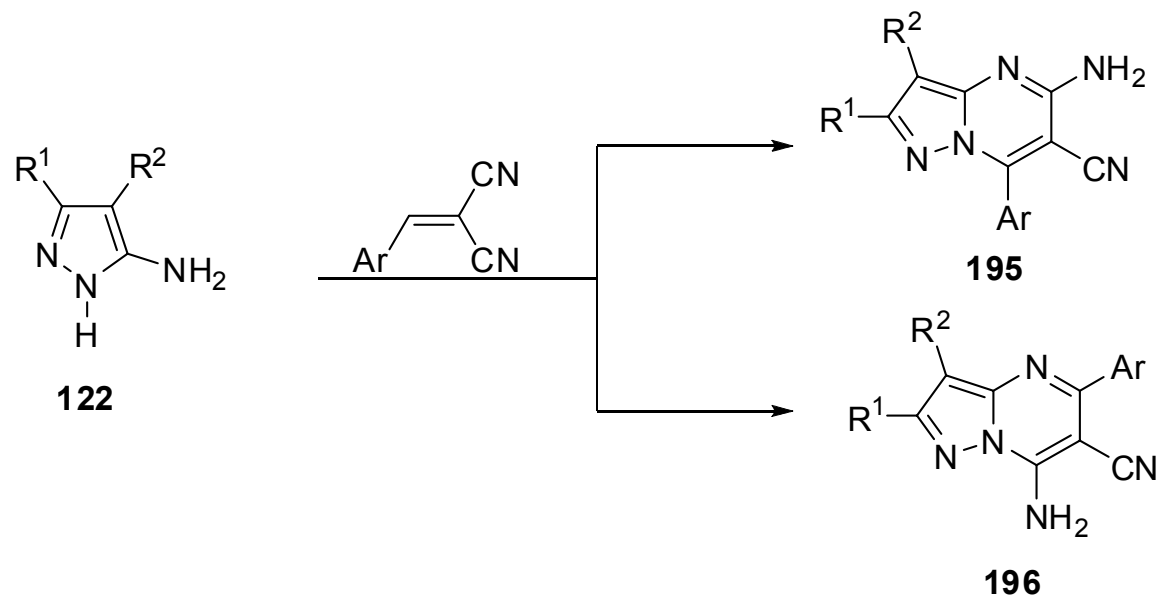

\section{Scheme 52}

Wendt et al. have recently reported on the reactivity of aminopyrazole toward benzylidene malononitrile and firmly established the structure of the product by an X-ray crystal structure determination. Thus, they noted that, in addition to 7-amino-pyrazolo[1,5-a]pyrimidine (196, Ar $=\mathrm{Ph} ; \mathrm{R}^{1}=\mathrm{R}^{2}=\mathrm{H}$ ) formed in ethanolic sodium ethoxide in $80 \%$ yield, a $7 \%$ yield of 198 was obtained. When the reaction was conducted in ethanolic triethylamine, a 68\% yield of 196 together with a $21 \%$ yield of $\mathbf{1 9 8}$ as side product was formed. However, in refluxing pyridine only 196 could be isolated. It is believed that $\mathbf{1 9 8}$ is formed as a result of initial formation of 197 (Scheme 53). ${ }^{110 \mathrm{~d}}$

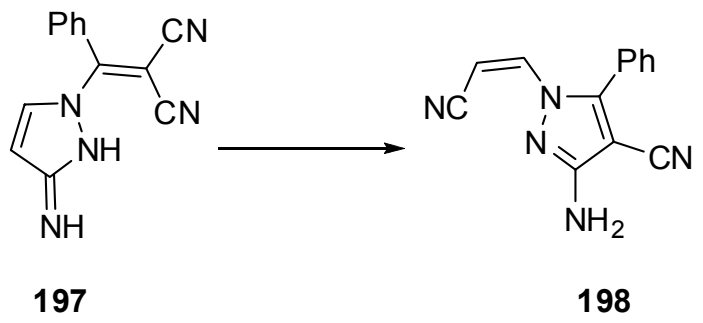

\section{Scheme 53}

The reaction of an aldehyde, an active methylene reagent and aminopyrazoles has been extensively investigated recently. It is believed that the active methylene reagent initially condenses with the aldehyde to yield an $\alpha, \beta$-unsaturated functional reagent that is then added to 
C-4 yielding an adduct that then subsequently cyclized yielding pyrazolo[3,4- $b]$ pyridine moieties. For example, a mixture of 168 and 199 reacting with 200 gave 201 with refluxing ethanol in the presence of $\mathrm{Et}_{3} \mathrm{~N}$, while, when the reaction was conducted in the presence of $t$ BuOK, 202 was formed (Scheme 54). ${ }^{111}$

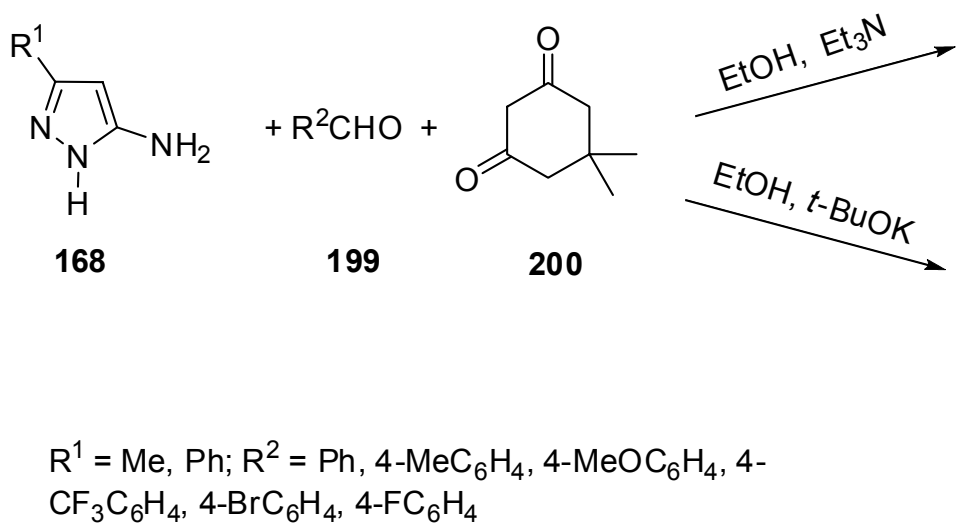

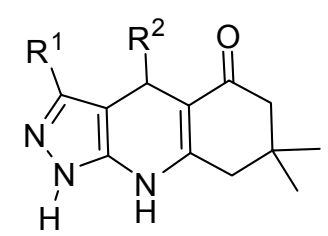

201

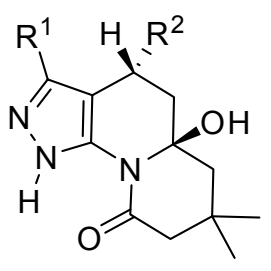

202

\section{Scheme 54}

Al-Mousawi et al. ${ }^{12}$ have reported that 1-phenyl-5-pyrazolamine 175 reacted with arylidenemalononitrile to yield pyrazolo[3,4- $b]$ pyridine 203, the structures of which were established by NOE. ${ }^{113}$ These products were obtained upon reacting 175 with the mixture of malononitrile and aromatic aldehydes in an ionic liquid (Scheme 55). ${ }^{114}$ Similarly, mixtures of aldehydes and ethyl cyanoacetate afforded 204. ${ }^{115}$ Also 203 was obtained from reacting 175 with aldehydes and 2-cyanoethanethioamide under microwave irradiation. ${ }^{116}$

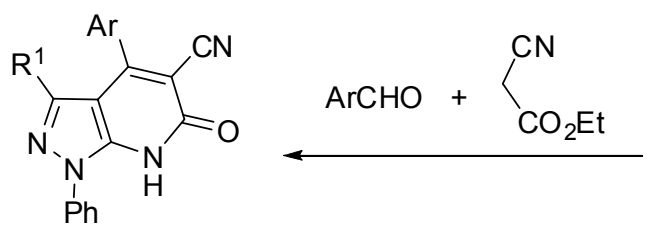

204

$\mathrm{R}^{1}=\mathrm{Me} ; \mathrm{Ar}=\mathrm{Ph}, 4-\mathrm{ClC}_{6} \mathrm{H}_{4}, 4-\mathrm{O}_{2} \mathrm{NC}_{6} \mathrm{H}_{4}$

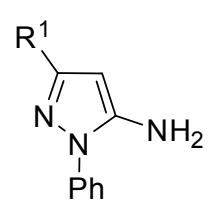

175

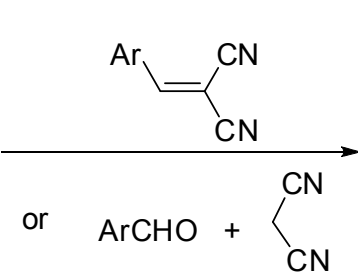

$\mathrm{R}^{1}=\mathrm{Me} ; \mathrm{Ar}=\mathrm{Ph}, 4-\mathrm{MeC}_{6} \mathrm{H}_{4}, 4-\mathrm{MeOC}_{6} \mathrm{H}_{4}, 4-$ $\mathrm{BrC}_{6} \mathrm{H}_{4}, 4-\mathrm{ClC}_{6} \mathrm{H}_{4}, 4-\mathrm{FC}_{6} \mathrm{H}_{4}, 4-\mathrm{O}_{2} \mathrm{NC}_{6} \mathrm{H}_{4}, 3-$ $\mathrm{O}_{2} \mathrm{NC}_{6} \mathrm{H}_{4}, 3-\mathrm{MeC}_{6} \mathrm{H}_{4}, 3,4-\mathrm{Me}_{2} \mathrm{C}_{6} \mathrm{H}_{3}, 3,4-$ $(\mathrm{MeO})_{2} \mathrm{C}_{6} \mathrm{H}_{3}, 3,4-\mathrm{Cl}_{2} \mathrm{C}_{6} \mathrm{H}_{3}$

\section{Scheme 55}

Quite similar to this reaction is the reaction of $\mathbf{1 7 5}$ with mixtures of aldehydes and aroylacetonitrile 205 to yield 206 (Scheme 56). ${ }^{117}$ 

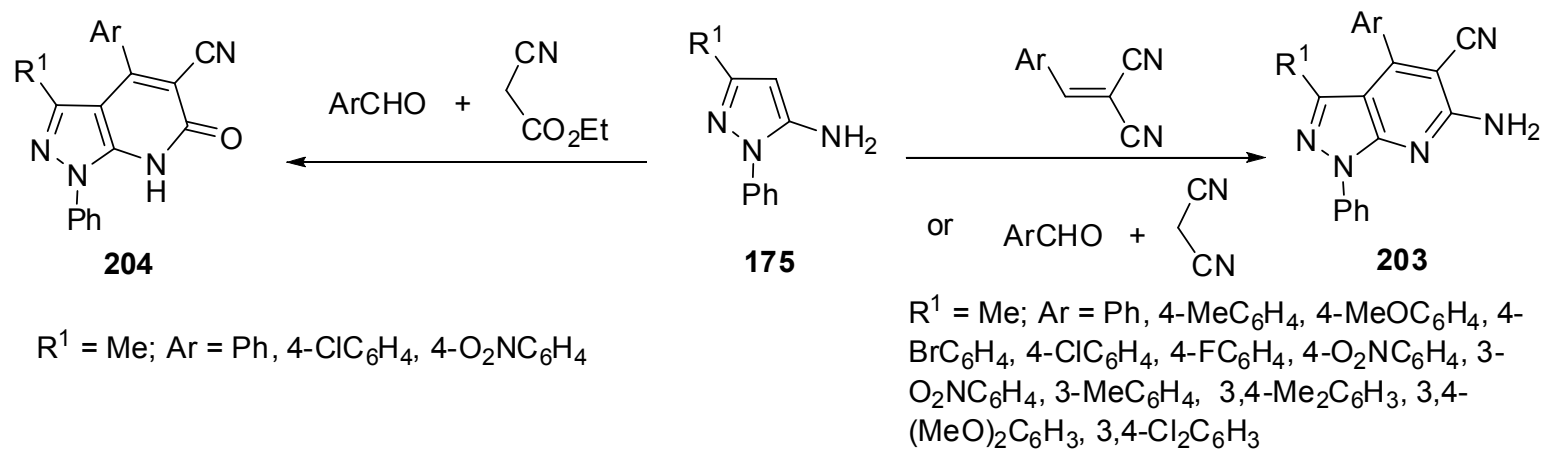

\section{Scheme 56}

This approach has been extensively utilized in recent years for the synthesis of 2(pyrazolo[1,5-a]pyrimidin-5-yl)benzoic acids (208) ${ }^{110 a, b}$ (Scheme 57).

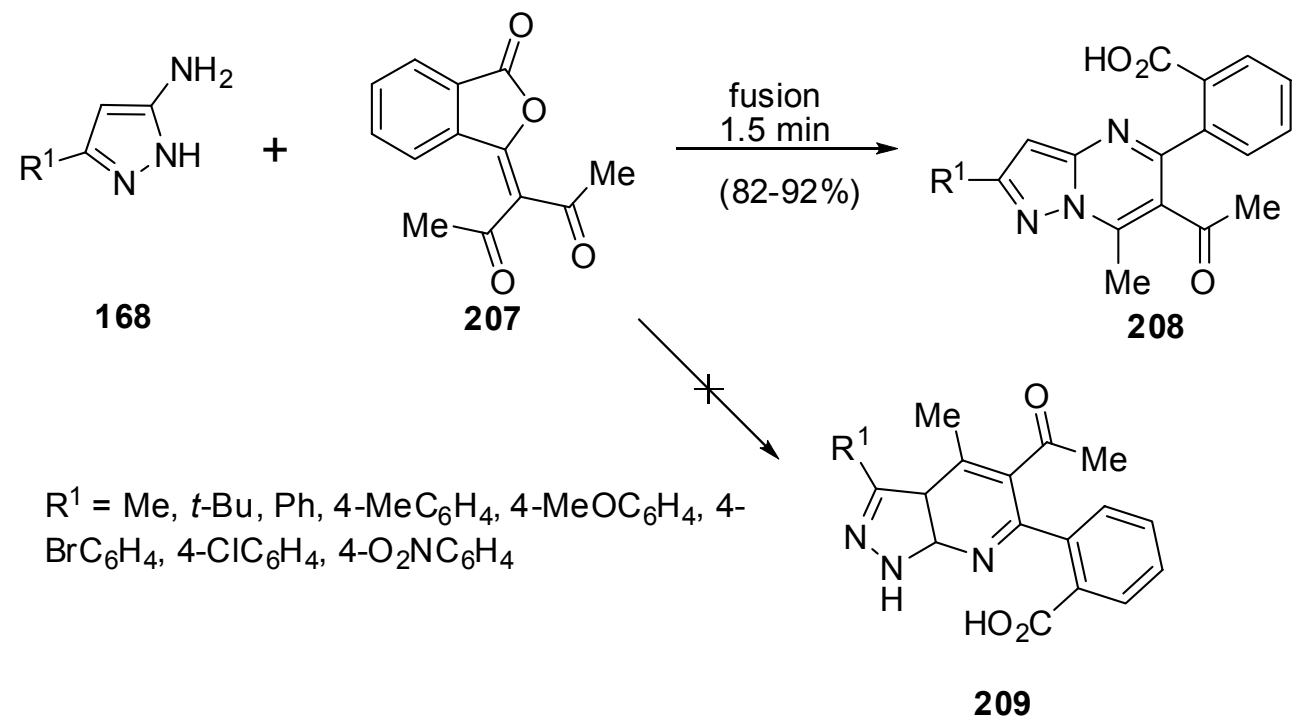

\section{Scheme 57}

Recently, cyclocondensation of $\mathbf{1 6 8}$ with diethyl benzylidenemalonate afforded 6,7dihydropyrazolo-[1,5-a]pyrimidin-5-one (210). Also, cyclocondensation of 168 with 2benzylidenemalonic acid in nitrobenzene gave dipyrazolo[3,4- $\left.b: 4^{\prime}, 3^{\prime}-e\right]$ pyridine $211^{118}$ (Scheme $58)$. 


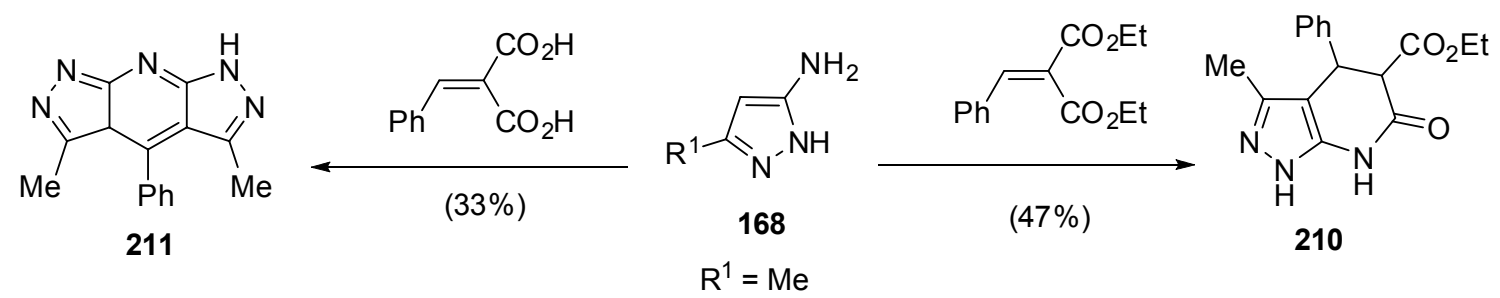

\section{Scheme 58}

The reaction of enaminones 131 with 122 afforded product 212 of initial attack at the exocyclic amino function as established by single crystal X-ray structure analysis. ${ }^{45 a, 119,120}$ Enaminonitriles behaved similarly. Thus 122 gave 213. ${ }^{44}$ Pyrazol-5-amine 122 reacted with 214 to yield 215 (Scheme 59). ${ }^{121-124}$ Interestingly, Zaleplon derivatives were prepared in this way. ${ }^{125}$ It has been reported that $\mathbf{1 2 2}$ reacted with $\mathbf{2 1 6}$ to yield the dihydropyrazolo[1,5-a]pyrimidine 217. ${ }^{126,127}$ Similarly, heating 122 with $\mathbf{2 1 8}$ gave 219. It is assumed that phenylvinylketone was initially formed on heating $\mathbf{2 1 8}$ and this then reacted with 122 to yield the final product. ${ }^{128}$

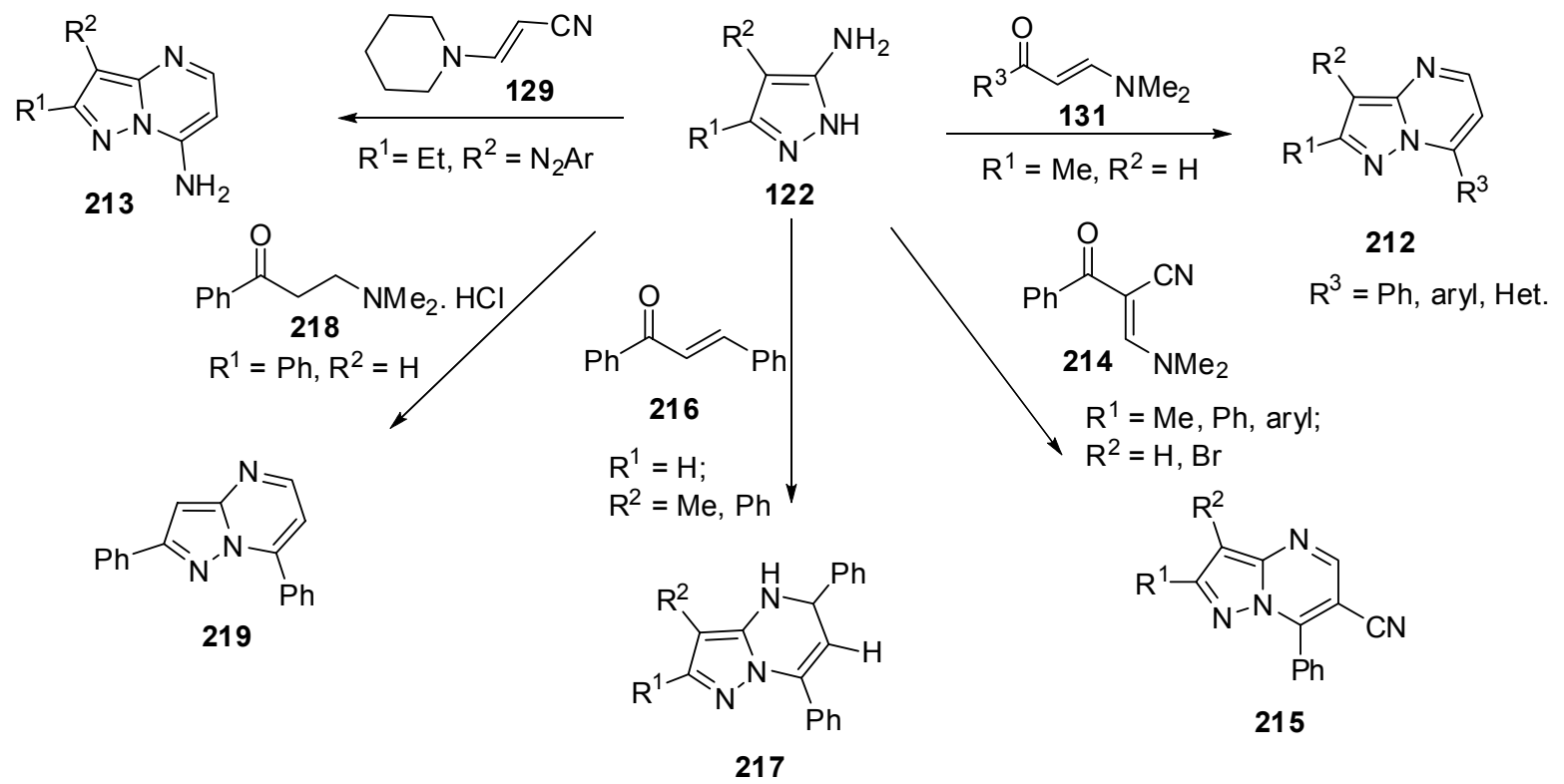

\section{Scheme 59}

Based on the enaminone methodology, the $\mathbf{2 2 0}$ reacted with aminopyrazole 7 to yield pyrazolo[1,5- $a$ ]pyrimidin-7-one 221. ${ }^{129}$ On the other hand, $N$-acyl-imidates 222 reacted with 7 to yield pyrazolo[1,5-a][1,3,5] triazine $\mathbf{2 2 3}^{130}$ (Scheme 60). 


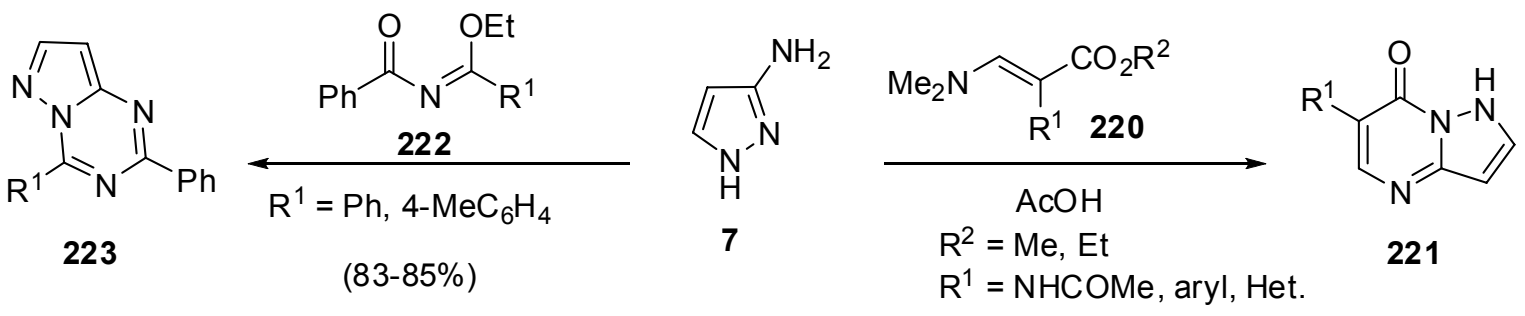

\section{Scheme 60}

Synthesis of the functionalized pyrazolo[1,5-a]pyrimidines were described from amniopyrazoles 122 and 3-hydroxy-2-arylacrylaldehydes 224 upon microwave irradiation or conventional heating to yield 225. ${ }^{27 \mathrm{c}}$ Also pyrazolo[1,5- $a$ ]pyrimidines 227 were obtained from gem $\alpha$-oxoketenedithioacetals $\mathbf{2 2 6}$ with aminopyrazoles $\mathbf{1 2 2}$ mainly at exocyclic amine moiety 131 (Scheme 61).<smiles>[R]c1c(SC)nc2ccnn2c1[R]</smiles>

227

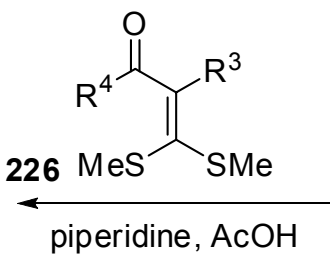

$(71-90 \%)$

$R^{1}, R^{2}=H$

$\mathrm{R}^{3}=\mathrm{H}, \mathrm{Me}$, cycloalkyl; $\mathrm{R}^{4}=\mathrm{Me}$, Et, alkyl, cycloalkyl, aryl, Het.

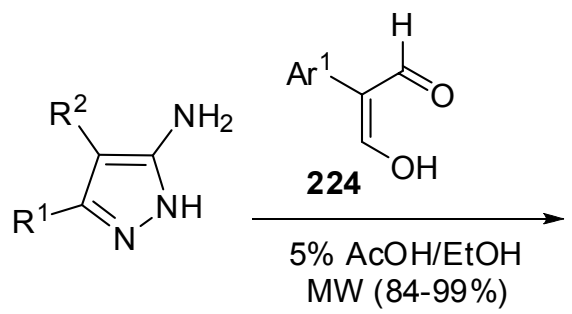

122 or cat. $\mathrm{AcOH} / \mathrm{EtOH}, \Delta$ $(40-60 \%)$

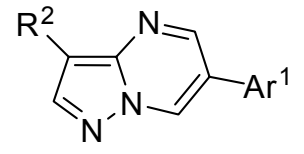

225

$\mathrm{R}^{1}=\mathrm{H} ; \mathrm{R}^{2}=\mathrm{Ph}$, Het.;

$\mathrm{Ar}^{1}=4-\mathrm{MeOC}_{6} \mathrm{H}_{4}, 4-$ $\mathrm{ClC}_{6} \mathrm{H}_{4}$, Het.

\section{Scheme 61}

Diethyl ethoxymethylenemalonate (228) reacted with aminopyrazoles 122 to yield 229. This was saponified to yield 230 which could be decarboxylated yielding pyrazolo[1,5-a]pyrimidin-7one 231. Compound 231 could be directly obtained via reacting 122 with ethyl formylacetate generated in situ from reaction of ethyl formate and ethyl acetate ${ }^{132}$ (Scheme 62). 


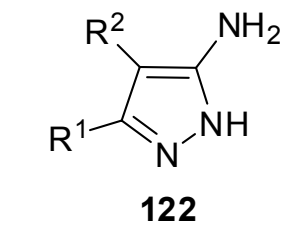

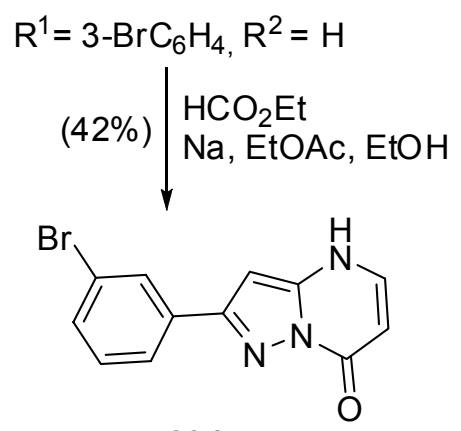

231

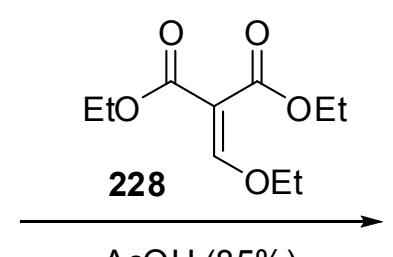

$\mathrm{AcOH}(85 \%)$

Dowtherm A<smiles>[R6]OC(=O)c1c[nH]c2cc(-c3cccc(Br)c3)nn2c1=O</smiles>

229

$\mathrm{NaOH}, \mathrm{EtOH}$

$(91 \%)$<smiles>O=C(O)c1c[nH]c2cc(-c3cccc(Br)c3)nn2c1=O</smiles>

230

\section{Scheme 62}

It has been found that the isomer of 231, pyrazolo[1,5-a]pyrimidin-5-one $\mathbf{2 3 3}$ was readily formed upon the treatment of $\mathbf{1 2 2}$ with 1,3-dimethyluracil (232) in ethanol. Structure of reaction products could be elucidated via NOE difference experiments with $N$-methylated 231 and $\mathbf{2 3 3}^{132}$ (Scheme 63).<smiles>[R]c1n[nH]c(N)c1[R]</smiles>

122
$\stackrel{\mathrm{NaOEt}, \mathrm{EtOH}}{\longrightarrow}$

(75\%)<smiles>O=c1ccn2nc(-c3cccc(Br)c3)cc2[nH]1</smiles>

233

$\mathrm{R}^{1}=3-\mathrm{BrC}_{6} \mathrm{H}_{4}, \mathrm{R}^{2}=\mathrm{H}$

\section{Scheme 63}

The reaction of 5-aminopyrazole-4-carbonitriles 140 with dimethyl acetylenedicarboxylate (DMAD) in DMSO in the presence of potassium carbonate gave pyrazolo[3,4- $b$ ]pyridine-5,6dicarboxylates 234 in $14-53 \%$ yields ${ }^{133}$ (Scheme 64). 


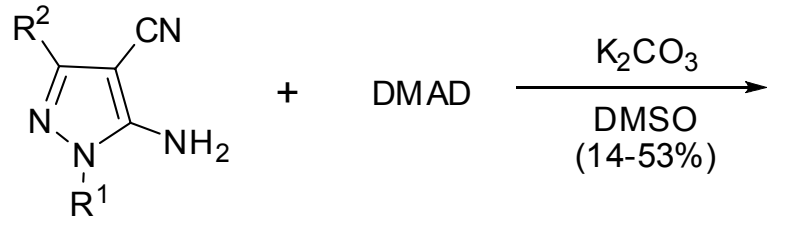

140

$\mathrm{R}^{1}=\mathrm{Ph}, 4-\mathrm{O}_{2} \mathrm{NC}_{6} \mathrm{H}_{4}, \mathrm{SO}_{2}-\mathrm{C}_{6} \mathrm{H}_{4}-4-\mathrm{Me}$, Het.

$\mathrm{R}^{2}=\mathrm{H}, \mathrm{Me}, \mathrm{Ph}, 4-\mathrm{Me}_{2} \mathrm{NC}_{6} \mathrm{H}_{4}$, SMe, S-aryl, Het.

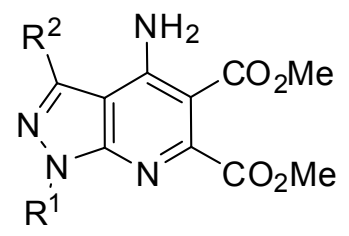

234

\section{Scheme 64}

The reaction of 175 with $\mathbf{2 3 5}$ in refluxing DMF gave pyrazolo[3,4- $b$ ]pyridine-6-carboxylic acid 236 in 39-48\% yields. The dihydro derivatives 237 were obtained in $68-72 \%$ yields when the reactions were conducted in AcOH. This product was contaminated with $\mathbf{2 3 6}^{134}$ (Scheme 65).

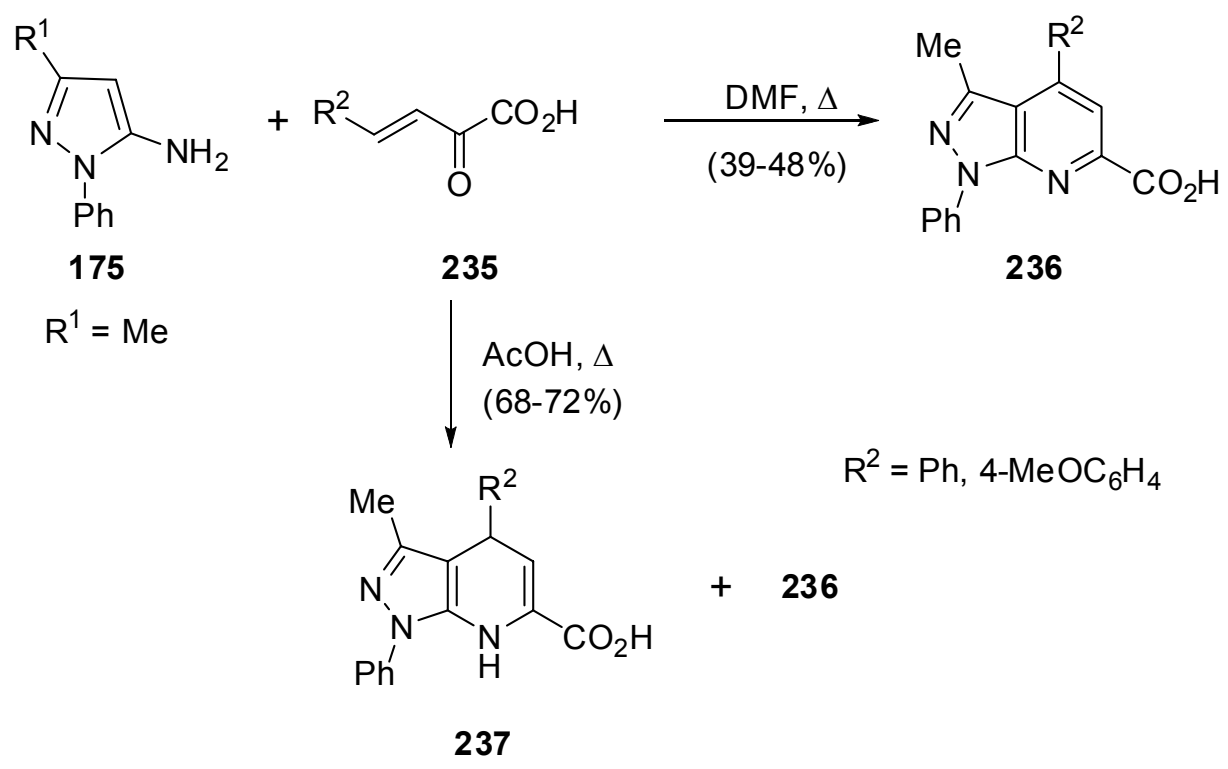

\section{Scheme 65}

On the other hand, mixture of $\mathbf{2 3 8}, \mathbf{2 3 9}$ and $\mathbf{2 4 0}$ were obtained from the reaction of $\mathbf{1 6 8}$ with $235^{134}$ (Scheme 66). 


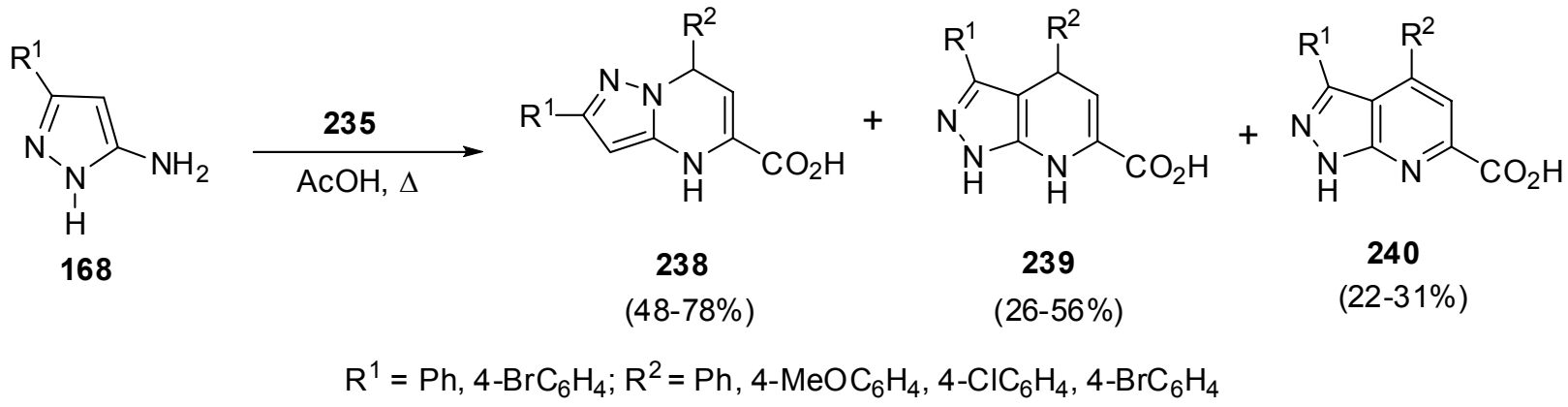

\section{Scheme 66}

The reaction of 241 with the same reagent 235 afforded 242 as sole product in $68-72 \%$ yields $^{134}$ (Scheme 67).

\section{Scheme 67}

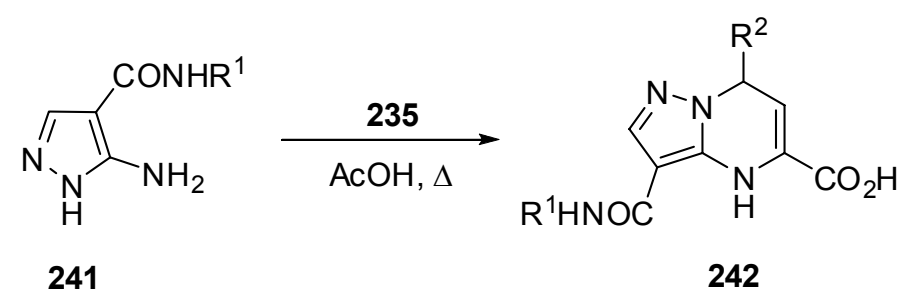

$$
\begin{aligned}
& \mathrm{R}^{1}=\mathrm{Ph}, 4-\mathrm{EtOC}_{6} \mathrm{H}_{4} ; \mathrm{R}^{2}=\mathrm{Ph}, 4- \\
& \mathrm{MeOC}_{6} \mathrm{H}_{4}, 4-\mathrm{ClC}_{6} \mathrm{H}_{4}
\end{aligned}
$$

A regioselective one-pot synthesis of pyrazolo[1,5-a]pyrimidine derivatives 246 from aminopyrazole 7 and $\alpha, \beta$-unsaturated imines 245 which was generated in situ from methyl phosphonate, nitrile, and aldehyde ${ }^{135}$ (Scheme 68).
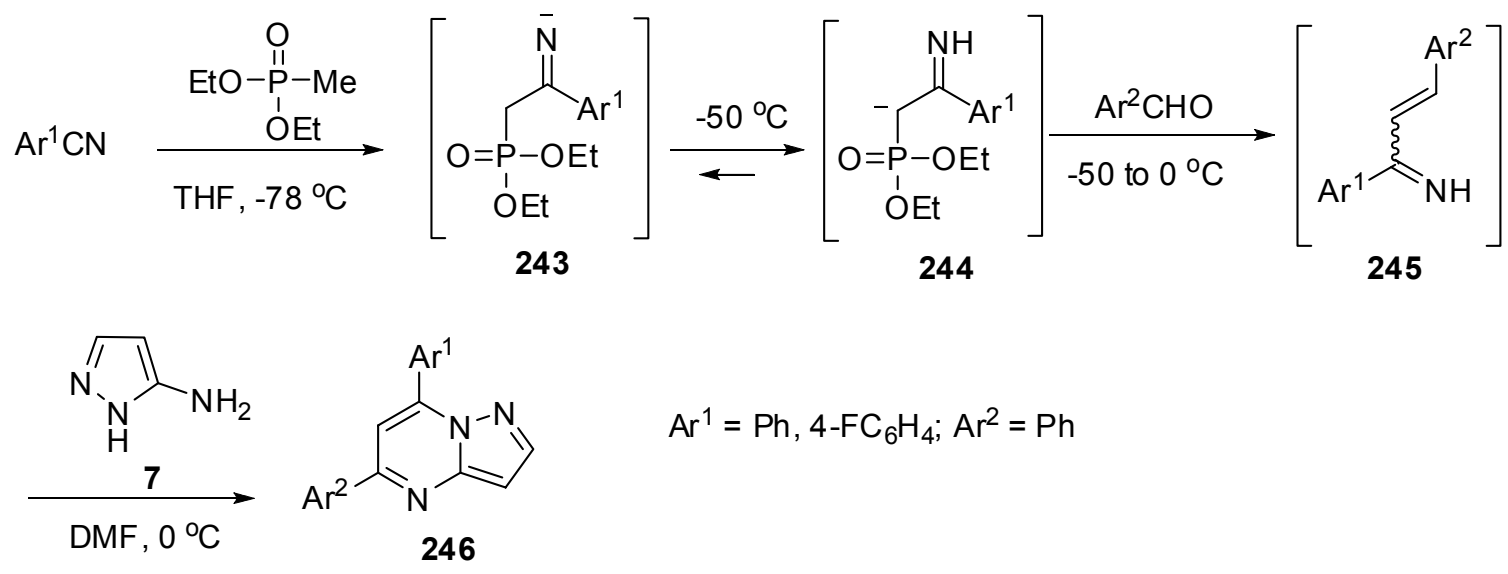

$$
\mathrm{Ar}^{1}=\mathrm{Ph}, 4-\mathrm{FC}_{6} \mathrm{H}_{4} ; \mathrm{Ar}^{2}=\mathrm{Ph}
$$

\section{Scheme 68}

(54-64\%) 
6.1.6. Reactions with aldehydes and ketones. The reaction of 1,3-dimethyl-5-pyrazolamine 32 and $p$-substituted benzaldehydes yielded four different compounds $\mathbf{2 4 7 - 2 5 0}{ }^{136}$ (Scheme 69).

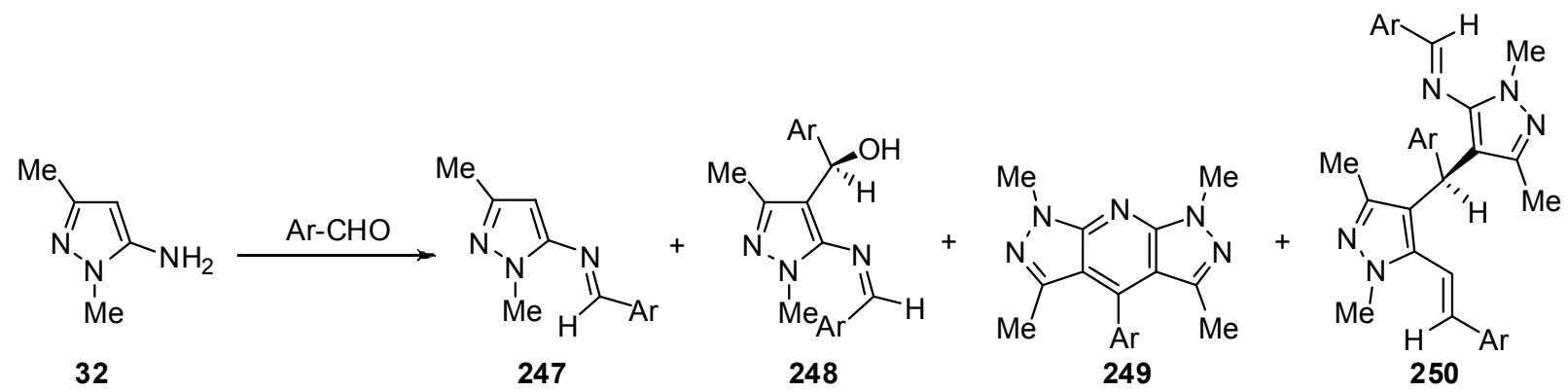
$\mathrm{Ar}=\mathrm{Ph}, 4-\mathrm{MeC}_{6} \mathrm{H}_{4}, 4-\mathrm{O}_{2} \mathrm{NC}_{6} \mathrm{H}_{4}$

\section{Scheme 69}

Under microwave irradiation in absence of solvent, 1-aryl-3-methyl-5-aminopyrazoles (251) reacted with aldehydes to yield dipyrazolo[3,4-b:4',3'-e]pyridine derivatives $\mathbf{2 5 2}^{137}$ (Scheme 70).

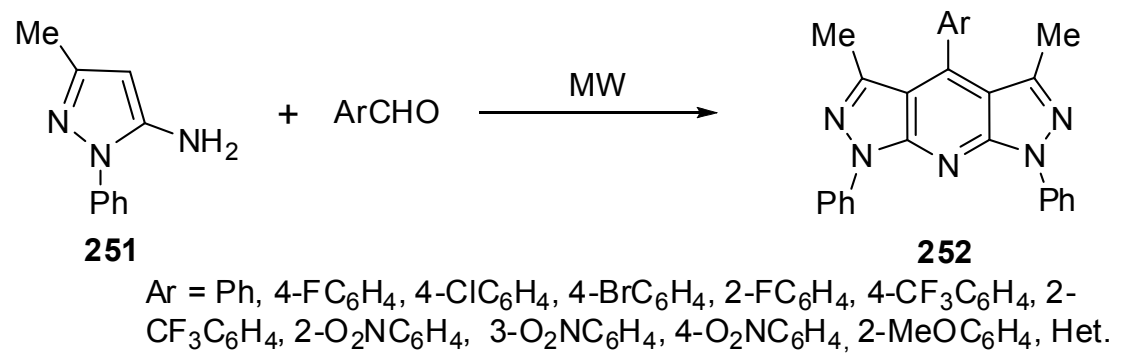

\section{Scheme 70}

A series of 1,3,6-trisubstituted and 1,3,5,6-tetrasubstituted pyrazolo[3,4- $b]$ pyridines 254 has been synthesized by Friedländer condensation of 5-aminopyrazole-4-carbaldehydes 253 with $\alpha$ methyle ketones such as acetone or acetophenones with $\mathrm{KOH}$ as a basic catalyst. Condensation with unsymmetrical ketones gave the mixture of isomeric products 255 and $\mathbf{2 5 6}{ }^{138}$ (Scheme 71).

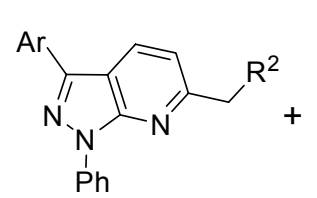

256

$(20-25 \%)$

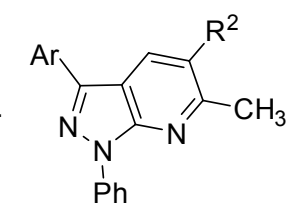

255 (51-55\%)

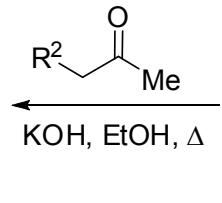<smiles>Nc1c(C=O)c(Br)nn1-c1ccccc1</smiles>

253

$\mathrm{Ar}=4-\mathrm{ClC}_{6} \mathrm{H}_{4}, 4-\mathrm{BrC}_{6} \mathrm{H}_{4}$

$\mathrm{R}^{1}=\mathrm{Me}, \mathrm{Ph}$, aryl

$\mathrm{R}^{2}=\mathrm{Me}, \mathrm{CH}_{2} \mathrm{CN}, \mathrm{CH}_{2} \mathrm{Ph}$, aryl, $\mathrm{CO}_{2} \mathrm{Et}$

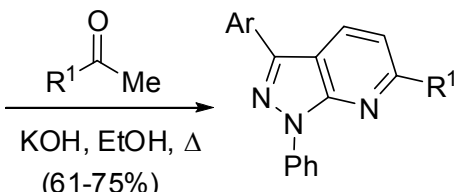

254

\section{Scheme 71}


Similarly, 253 condensed with cyclohexanedione 257 and with cyclopentanone (258) to yield 259 and 260, respectively ${ }^{139}$ (Scheme 72).<smiles>[Al]c1nn(-c2ccccc2)c2nc3c(cc12)CCC3</smiles>

260

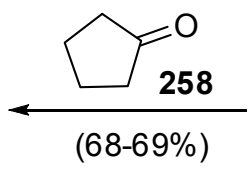<smiles>Nc1c(C=O)c(Br)nn1-c1ccccc1</smiles>

253

$\mathrm{Ar}=4-\mathrm{BrC}_{6} \mathrm{H}_{4}, 4-\mathrm{ClC}_{6} \mathrm{H}_{4}$

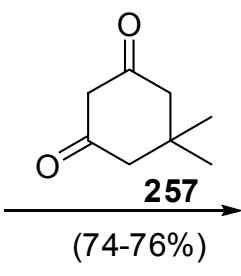<smiles>CC1(C)CC(=O)c2cc3c([Al])nn(-c4ccccc4)c3nc2C1</smiles>

259

\section{Scheme 72}

The reaction of 1-phenyl-3-methyl-5-aminopyrazole (175) with 261 in ethanol in the presence of $p$-toluenesulfonic acid afforded 262 or 263 depending on the reaction conditions ${ }^{140}$ (Scheme 73).

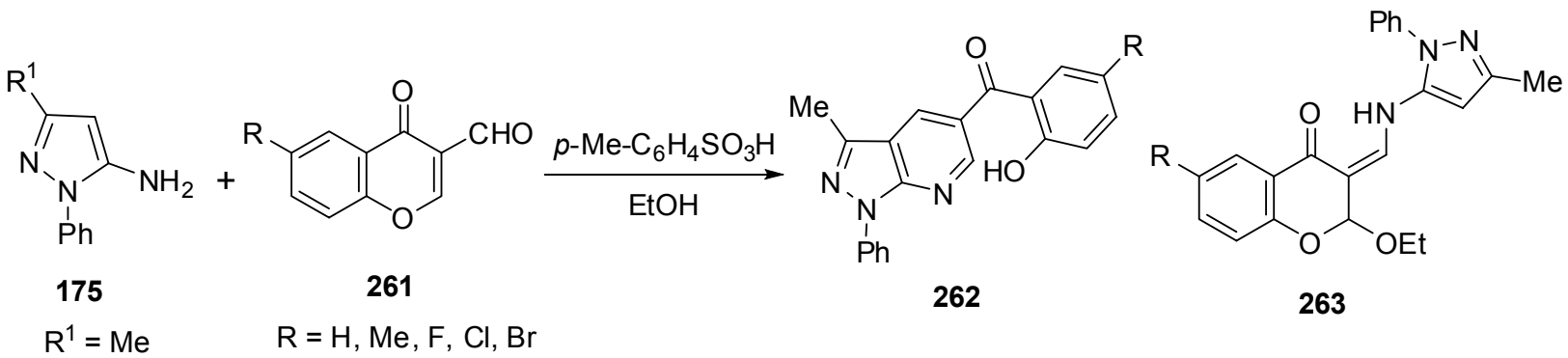

Scheme 73

Sodium naphthoquinone-4-sulfonate 264 reacted with 5-aminopyrazole (7) to yield pyrazolyl-naphthoquinone $\mathbf{2 6 5}^{141}$ (Scheme 74).

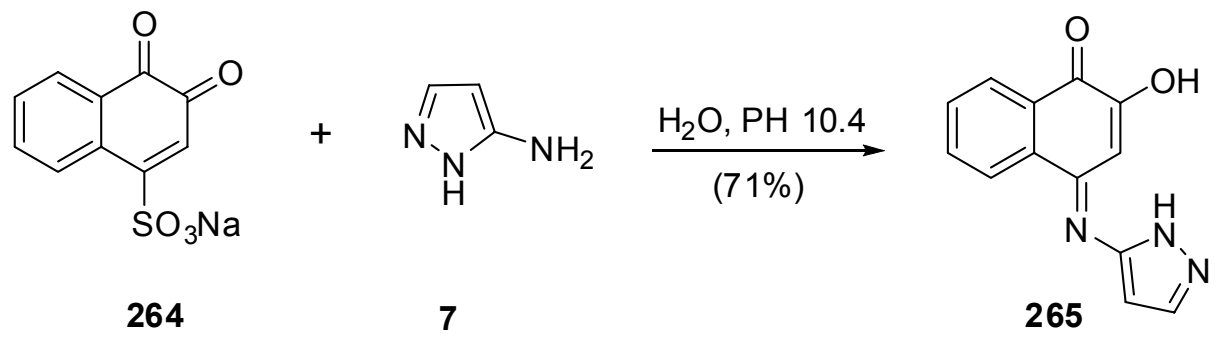

\section{Scheme 74}


6.1.7. Cycloaddition and dipolar cycloadditions. The [4+2] cycloaddition of various 5aminopyrazoles 32 with 1,3,5-triazine-2,4,6-tricarboxylic acid triethyl ester (266) have been reported to yield 269 via intermediacy of 267 and $268^{142}$ (Scheme 75).

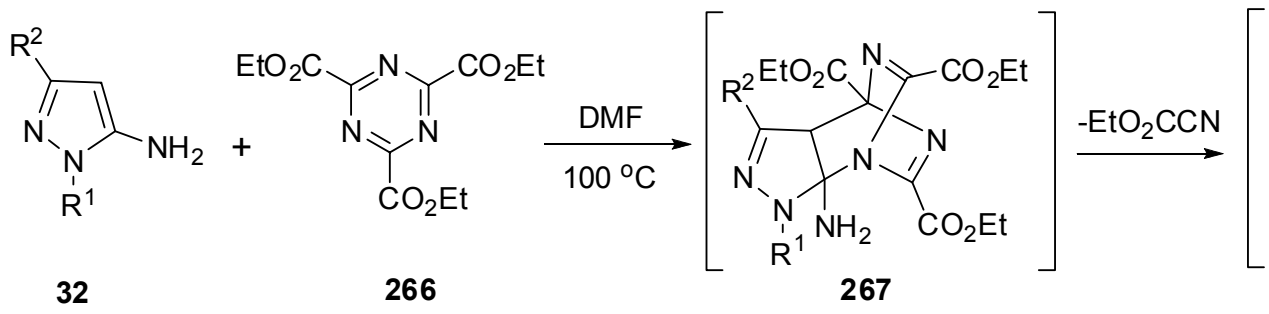

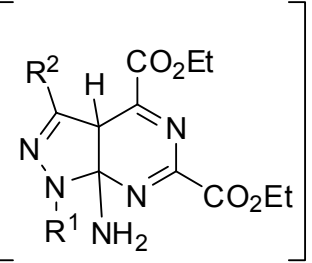

268
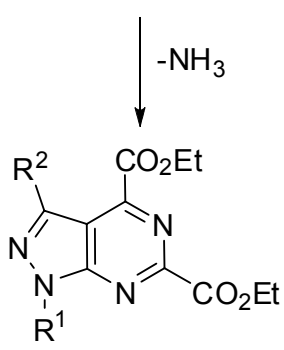

269

\section{Scheme 75}

Treatment of $\mathbf{2 7 0}$ and benzaldehyde in acetonitrile at room temperature in the presence of $\mathrm{FeCl}_{3}$ with alkenes gave cycloadducts 272. It was assumed that 271 was initially formed ${ }^{143}$ (Scheme 76).<smiles>Nc1n[nH]c2nc(-c3ccccc3)cc(C(F)(F)F)c12</smiles>

270<smiles>COc1ccccc1</smiles>

271

$$
\begin{aligned}
& R^{1}=R^{2}=H(41 \%) \\
& R^{1}=M e, R^{2}=P h(70 \%)
\end{aligned}
$$

\section{Scheme 76}

3-Aminopyrazole derivatives 122 reacted with nitrile imines 273 (generated in situ) to yield pyrazolo[5,1-c]-1,2,4-triazoles 275 via intermediacy of 274. ${ }^{144}$ Some researchers isolated also 276. ${ }^{144 a, 145}$ This reaction has been extensively investigated and it was found that the nature of the end product depends on the nature of substituents on 122 and $273^{146}$ (Scheme 77). 


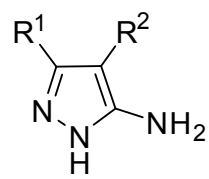

122

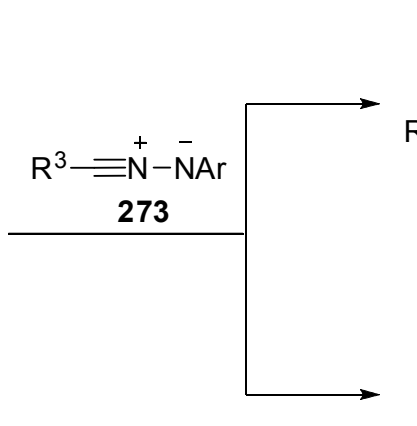

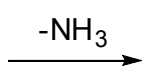

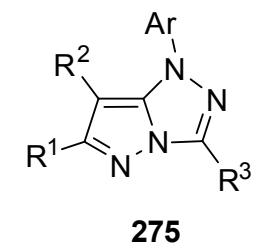
$\mathrm{R}^{1}=\mathrm{Me}, \mathrm{Ph}, \mathrm{Br} ; \mathrm{R}^{2}=\mathrm{H}$, $\mathrm{Ph} ; \mathrm{R}^{3}=$ aryl; $\mathrm{Ar}=\mathrm{Ph}$

\section{Scheme 77}

6.1.8. Intramolecular cyclization. The pyrazolo[5,1-c] benzo-1,2,4-triazine 5 -oxide system is obtained via intramolecular cyclization between the nitro and amino groups under basic conditions of suitable 5-amino-2'-nitrophenyl-pyrazoles. ${ }^{143}$ Thus, treating 277 with $10 \% \mathrm{NaOH}$ solution afforded $\mathbf{2 7 8 ^ { 1 4 7 }}$ (Scheme 78 ).<smiles>[R]c1cc(-n2ncc([R])c2N)c([N+](=O)[O-])cc1[R]</smiles>

$\mathrm{R}^{1}=\mathrm{Me}, \mathrm{NH}_{2} ; \mathrm{R}^{2}=\mathrm{N}_{2}$ aryl; $\mathrm{R}^{3}=\mathrm{COMe}, \mathrm{COPh} ; \mathrm{Ar}=\mathrm{Ph}$<smiles>[R]C(=NN[AlH2])n1nc([R])c([R])c1N</smiles>

276

$$
\mathrm{R}^{1}=\mathrm{Me}, \mathrm{NH}_{2}, \mathrm{R}^{2}=\mathrm{N}_{2} \mathrm{aryl} ; \mathrm{R}^{3}=\mathrm{COMe}, \mathrm{COPh}, \mathrm{Ar}=\mathrm{Ph}
$$


<smiles>[X]c1cnc(Cl)nc1Cl</smiles>

279<smiles>[R]c1cc(N)n[nH]1</smiles>

280<smiles>CCN1CCCCC1</smiles><smiles>[R]c1cc(Nc2nc(Cl)ncc2[X])n[nH]1</smiles>

281

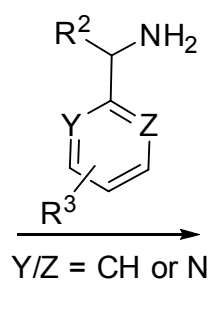

$\mathrm{R}^{1}=$ cyclopropyl, $\mathrm{H} ; \mathrm{R}^{2}=\mathrm{H},(R)-\mathrm{Me},(S)-\mathrm{Me},(R)-\mathrm{CH}_{2} \mathrm{OH},(R)-\mathrm{CH}_{2} \mathrm{OH}$; $\mathrm{R}^{3}=\mathrm{H}, 3-\mathrm{OMe}, 2-\mathrm{Cl}, 4-\mathrm{F}, 4-\mathrm{Cl} ; \mathrm{X}=\mathrm{Br}, \mathrm{Cl}$

\section{Scheme 79}

The condensation of 5-amino-1-phenyl-3-methylpyrazole (175) with dimethylformamide dimethyl acetal and $N$-phenylmaleimide (284) gave 285. Compound 283 was proposed as an intermediate $^{149}$ (Scheme 80).

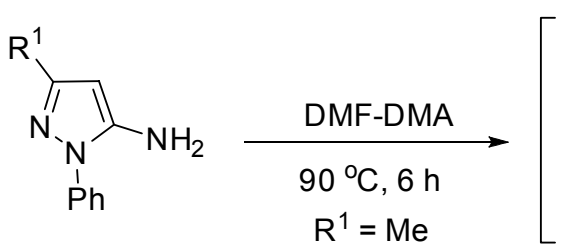

175

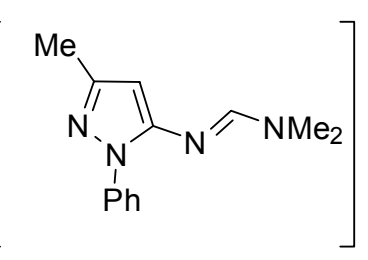

283<smiles>[R20][Y]1C[R3]([R])=CC=[Z]1C([R])Nc1ncc([X])c(Nc2cc([R1])[nH]n2)n1</smiles>

\section{Scheme 80}

Treatment of 5-amino-1 $H$-pyrazole-4-carbonitrile (286) with ethoxycarbonyl-isothiocyanate (287) gave corresponding pyrazolothiourea $\mathbf{2 8 8}$ that was alkylated and cyclized to yield the pyrazolotriazine $\mathbf{2 8 9} .^{150}$

Condensation of 286 with triethyl orthoformate afforded 290 which reacted with acylhydrazines to afford $\mathbf{2 9 1}$ that could be cyclized into $\mathbf{2 9 2}^{151}$ (Scheme 81). 


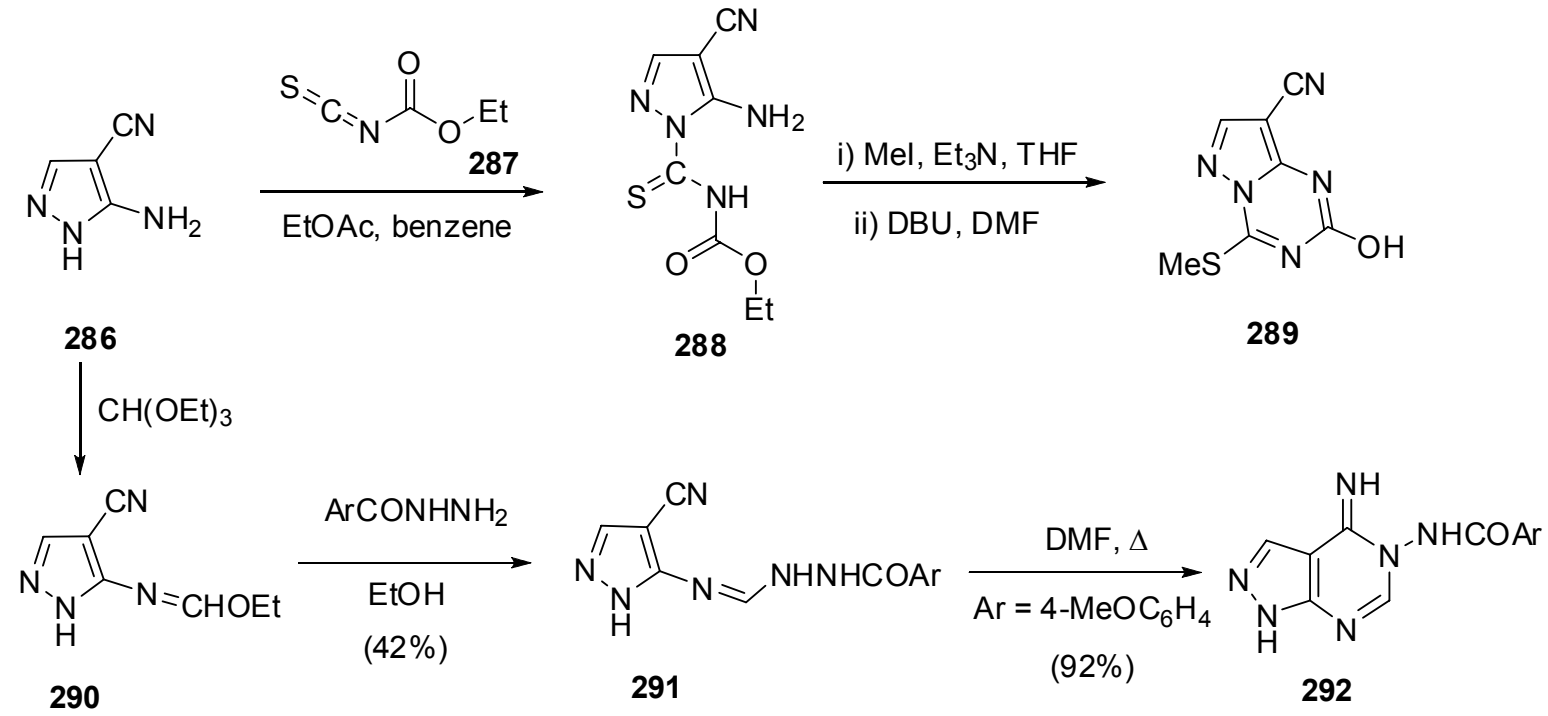

\section{Scheme 81}

Acylation of compound 293 with acetic anhydride afforded 294, which coupled with benzenediazonium chloride and subsequently cyclized into $\mathbf{2 9 5}^{108}$ (Scheme 82).<smiles>CC(=O)Nc1[nH]nc2c(C)nn(-c3ccccc3)c(=O)c12</smiles>

\section{Scheme 82}

The reaction of 296 with DMF-DMA gave 297 that reacted with amines $(\mathrm{X}=\mathrm{CN})$ to yield 298. Reaction of 297 with hydrazines; $X=\mathrm{CO}_{2}$ Et gave 299 ${ }^{152,153}$ (Scheme 83). 


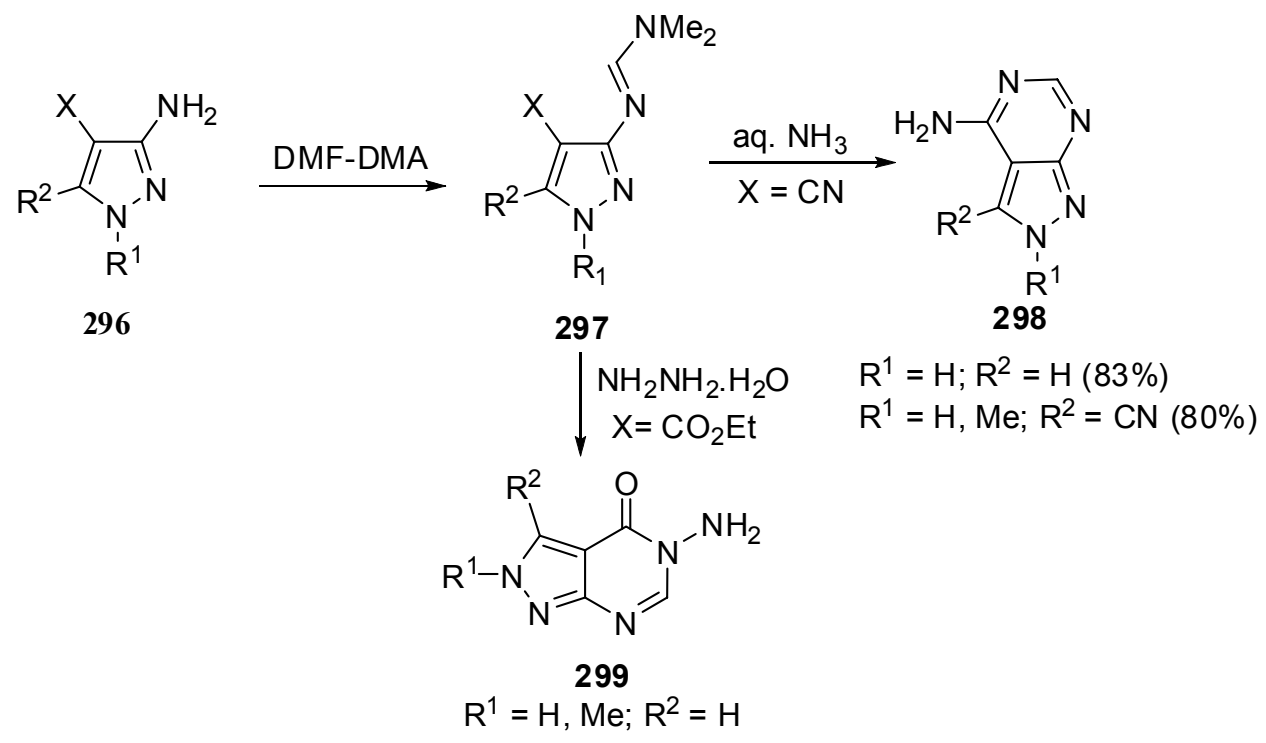

\section{Scheme 83}

The parallel solution-phase synthesis of more than 2200 7-trifluoromethyl-substituted pyrazolo[1,5-a]pyridines and 4,5,6,7-tetrahydropyrazolo[1,5-a]pyrimidine carboxamides on a 50-100 mg scale has been accomplished via condensing 5-aminopyrazole derivatives with the corresponding trifluoromethyl- $\beta$-diketones. ${ }^{154}$

The condensation of 1,3,5-triketone 301 with 5-amino-3-methylpyrazole (300) afforded $\mathbf{3 0 2}$. Refluxing the latter in methanol afforded $\mathbf{3 0 3}^{155}$ (Scheme 84).

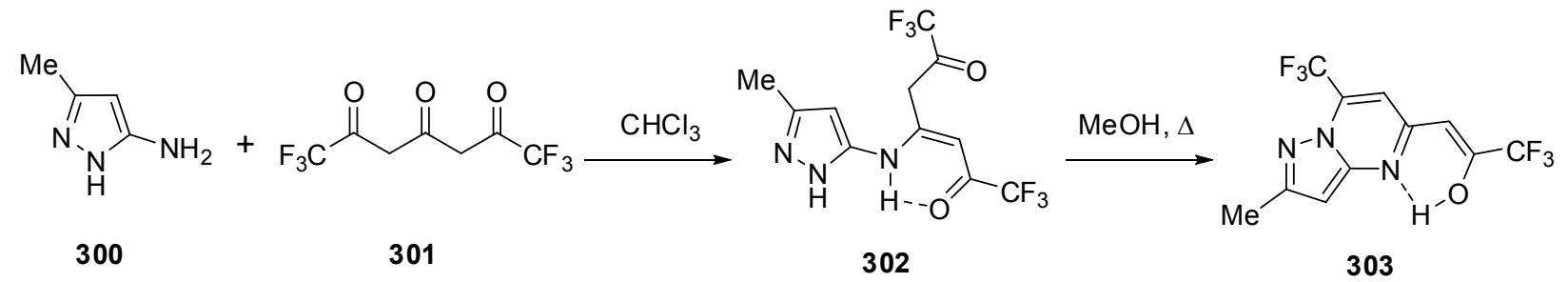

\section{Scheme 84}

The reaction of $\mathbf{3 0 0}$ with 2,6-bis(trifluoromethyl)-4H-pyran-4-one (304) in methanol gave a mixture of 303, 305, and 306. ${ }^{155}$ On the other hand, 2-benzylidene-5,5-dimethylcyclohexane-1,3dione (307) reacted with $\mathbf{3 0 0}$ to yield pyrazolo[3,4-b]quinolinone $\mathbf{3 0 8}$ in $61 \%$ yield ${ }^{156}$ (Scheme $85)$. 


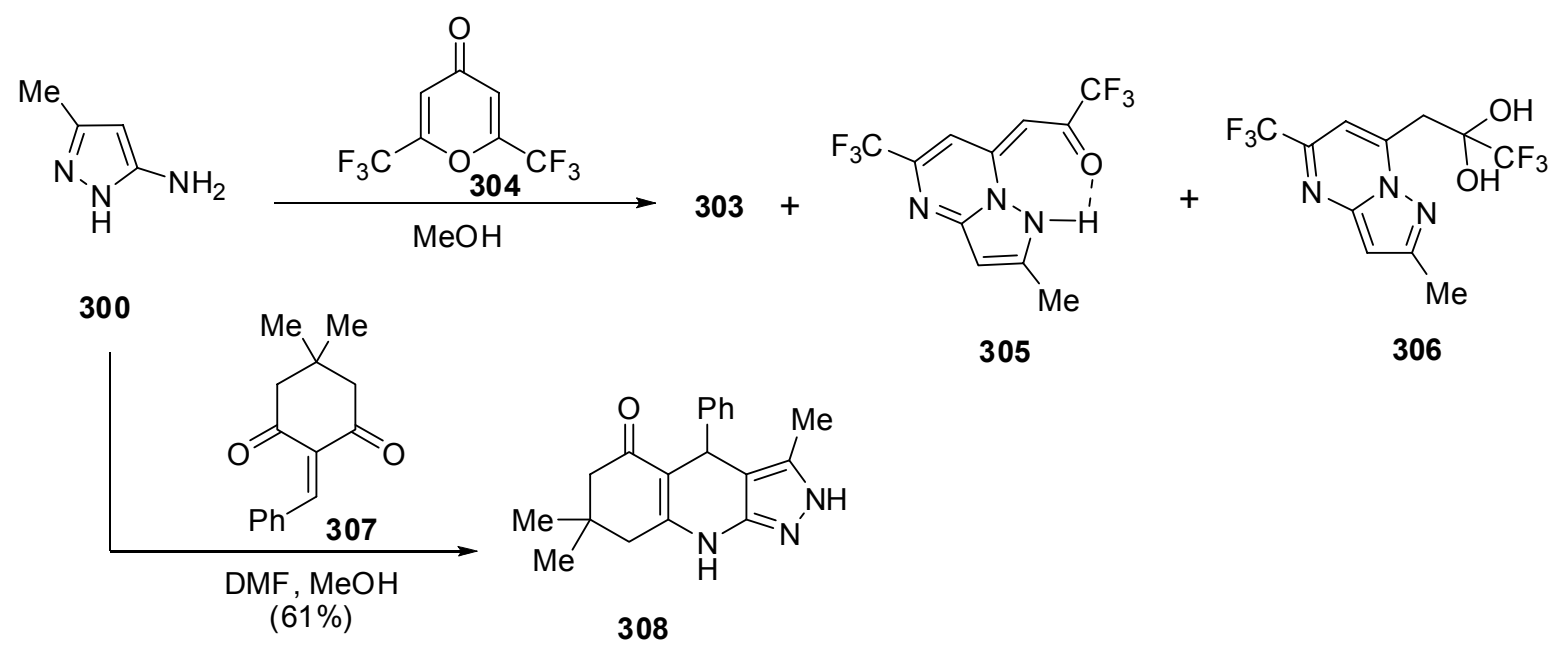

\section{Scheme 85}

Cyclization of 309 with $\mathrm{POCl}_{3}$ gave 4-chloro-1,3-dimethyl-pyrazolo[3,4-b]quinoline 310, that was used recently as an intermediate for synthesis of a series of 4-amino- $N$-phenyl- $1 H$ pyrazolo[3,4-b]quinolines which were potent inducers of apoptosis ${ }^{157}$ (Scheme 86).<smiles>Cc1cc(Nc2ccccc2C(=O)O)n(C)n1</smiles>

309<smiles>COc1ccc(S(C)(=O)=O)cc1</smiles>

$\mathrm{R}=\mathrm{H}, 6-\mathrm{Me}, 8-\mathrm{Me}, 8-\mathrm{NO}_{2}$<smiles>Cc1nn(C)c2nc3ccccc3c(Cl)c12</smiles>

310

\section{Scheme 86}

\subsection{4-Aminopyrazoles}

As expected for an aromatic amine, the 4-aminopyrazole 311 was diazotizable. The diazonium salt 312 was coupled with malononitrile to yield $\mathbf{3 1 3}^{67}$ (Scheme 87).

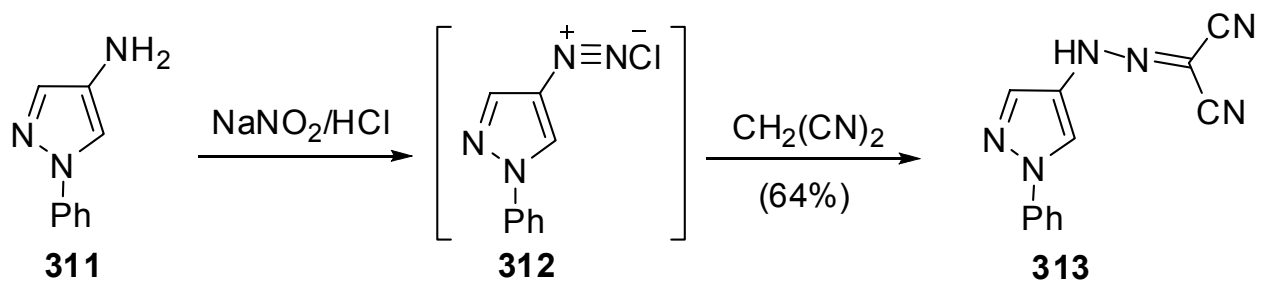

\section{Scheme 87}


Diazotization of 3-acetyl-4-aminopyrazole 314 gave pyrazolo[4,3-c]pyridazine derivatives 315 which smoothly cyclized into 316. And condensing of $\mathbf{3 1 4}$ with malononitrile in refluxing ethanol gave pyrazolo[4,3-b]pyridine derivatives $317^{158}$ (Scheme 88).<smiles>CCOC(=O)c1c2nc(N)c(C#N)c(C)c2nn1[Al]</smiles>

317<smiles>CCOC(=O)c1c(N)c(C(C)=O)nn1[Ga]=[Te]</smiles>

314

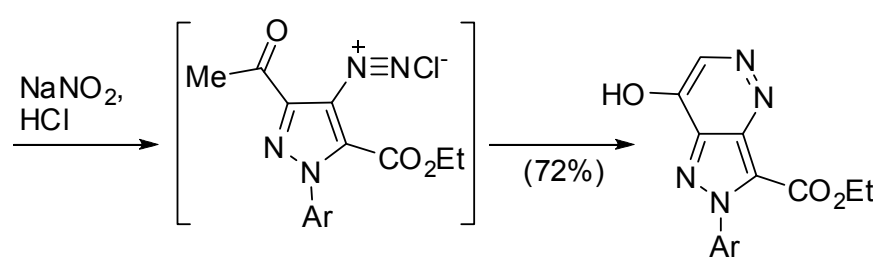

315

316

\section{Scheme 88}

The utility of 4-aminopyrazole-5-carboxamide derivatives as precursors to pyrazolo[4,3$d$ ]pyrimidines has recently been surveyed by Elnagdi et al. ${ }^{3}$ In addition to this, the reaction of 318 with 1,4-dioxane-2,6-dione (319) afforded 320 that readily cyclized into $\mathbf{3 2 1}{ }^{159}$ (Scheme 89).<smiles></smiles>

\section{Scheme 89}

The reaction of $\mathbf{3 2 2}$ with ethyl acetate gave pyrazolo[4,3- $d]$ pyrimidin-7-ones $\mathbf{3 2 3 a}{ }^{160}$ Similarly, 322 reacted with triethyl orthoacetate to yield $\mathbf{3 2 3 b}^{161}$ (Scheme 90).<smiles>[R]c1nn([R1])c2c(=O)nc(C)[nH]c12</smiles>

$323 b$

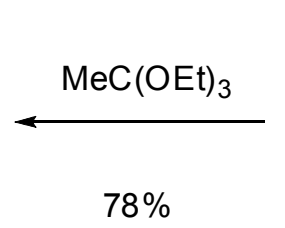<smiles>[R]c1nn([R1])c(C(N)=O)c1N</smiles>

322

$$
\mathrm{R}^{1}=\mathrm{Me}, \mathrm{R}^{2}=n-\mathrm{Pr}
$$<smiles>CCOC(C)=O</smiles><smiles>[R]c1nc2c(=O)nc([NH3+])[nH]c2c(=O)n1[R]</smiles>

$323 a$

\section{Scheme 90}


Unexpectedly, it was reported that 1,5-dimethyl-4-aminopyrazole 324 reacted with 325 to give intermediate $\mathbf{3 2 6}$ that reacted with $\mathbf{3 2 7}$ to afford $\mathbf{3 2 8}^{162}$ (Scheme 91).

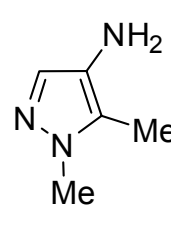

324<smiles>[N-]=[N+]c1ccc[nH+]c1Cl</smiles>

325

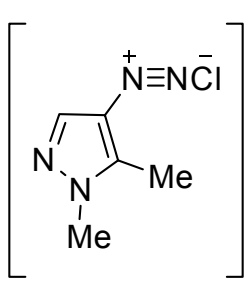

326
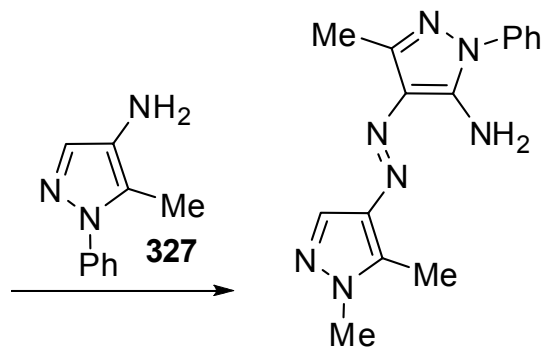

328

\section{Scheme 91}

\subsection{1-Aminopyrazole}

Little has been reported. Oxidative rearrangement of $\mathrm{N}$-aminopyrazole 329 to the 1,2,3-triazine 330 by lead tetraacetate, ${ }^{68 a}, 69$ nickel peroxide-AcOH,${ }^{69}$ or $\mathrm{NaIO}_{4}\left(\mathrm{KIO}_{3}\right)$ have been reported ${ }^{163}$ (Scheme 92).

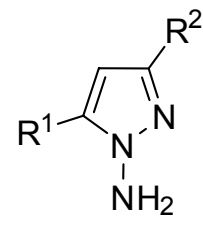

329

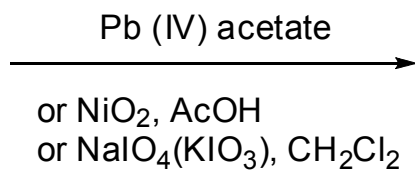

$\mathrm{R}^{1}=\mathrm{H}, \mathrm{Me}, \mathrm{Ph} ; \mathrm{R}^{2}=\mathrm{Me}, \mathrm{Ph}$<smiles>[R]c1cc([18OH])nnn1</smiles>

330

\section{Scheme 92}

Treatment of $\mathbf{5 8}$ with $48 \% \mathrm{HBr}$ gave $7 .{ }^{50}$ On the other hand, halogenation gave $\mathbf{3 3 1}$ and $\mathbf{3 3 2}^{164}$ (Scheme 93).

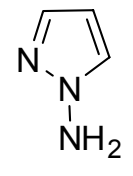

58

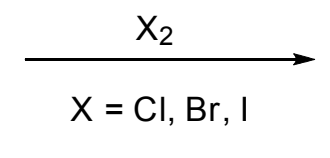<smiles>[X]c1cnn(N)c1</smiles>

331<smiles>[X]c1cnnnc1</smiles>

332

Scheme 93 


\section{References}

1. (a) Vinogradov, V. M.; Dalinger, I. L.; Shevelev, S. A. Khim.-Farm. Zh. 1994, 28, 37. (b) Giuseppe, D.; Salvatore, P.; Demetrio, R. Trends Heterocycl. Chem. 1991, 2, 97.

2. (a) Pevarello P.; Vulpetti, A. Inhibitors of Cyclin-Dependent Kinases as Anti-Tumor Agents: Pyrazoles as efficient adenine-mimetic heterocycles for the discovery of CDK inhibitors; Smith P. J.; Yue, E. W. Eds.; CRC Press, 2007; Chapter 15, pp 323-347. (b) Stanovnik, B.; Svete, J. Sci. Synth. 2002, 12, 15. (c) Svete, J. ARKIVOC 2006, (vii), 35.

3. Elnagdi, M. H.; Al-Awadi, N.; Abdelhamid, I. A. In Comprehensive Heterocyclic Chem. III; Katritzky, A. R.; Ramsden, C. A.; Scriven, E. F. V.; Taylor, R. J. K. Eds.; Elsevier: Oxford, 2008; Vol. 10 (12), pp 599-659.

4. Wu, Y.-C. ; Zou, X.-M.; Hu, F.-Z.; Yang, H.-Z. J. Heterocycl. Chem. 2005, 42, 609.

5. Chebanov, V. A.; Saraev, V. E.; Desenko, S. M.; Chernenko, V. N.; Knyazeva, I. V.; Groth, U.; Glasnov, T. N.; Kappe, C. O. J. Org. Chem. 2008, 73, 5110.

6. Jachak, M. N.; Avhale, A. B.; Ghotekar, B. K.; Kendre, D. B.; Toche, R. B. J. Heterocycl. Chem. 2008, 45, 1221.

7. Peruncheralathan, S.; Yadav, A. K.; Ila, H.; Junjappa, H. J. Org. Chem. 2005, 70, 9644.

8. (a) Migliara, O.; Raffa, D.; Plescia, S.; Cusimano, M. G. ; Carbone A. ARKIVOC 2009, (ii), 1. (b) Toto, P.; Chenault, J.; El Hakmaoui, A.; Akssira, M.; Guillaumet, G. Synth. Commun. 2008, 38, 674. (c) Hill G. B.; Mortlock, A. A. Synthesis 2007, 1697. (d) Emelina, E. E.; Petrov, A. A.; Firsov, A. V. Russ. J. Org. Chem. 2007, 43, 471. (e) Rao, V. V. V. N. S. R.; Lingaiah, B. P. V.; Reddy, G. V.; Ezikiel, G.; Yadla, R.; Rao, P. S. ARKIVOC 2006, (xii), 51. (f) Daidone, G.; Raffa, D.; Plescia, F.; Maggio, B.; Roccaro, A. ARKIVOC 2002, (xi), 227. (g) Elnagdi, M. H.; Sadek, K. U.; Galil, F. M. A.; Hassan, S. M. E. Arch. Pharm. 1988, 321, 851.

9. Hoepping, A.; Diekers, M.; Deuther-Conrad, W.; Scheunemann, M.; Fischer, S.; Hiller, A.; Wegner, F.; Steinbach, J.; Brust, P. Bioorg. Med. Chem. 2008, 16, 1184.

10. Wawer, I.; Pisklak, M.; Chilmonczyk, Z. J. Pharm. Biomed. Anal. 2005, 38, 865.

11. Elnagdi, M. H.; Al-Awadi, N.; Erian, A. W. in Comprehensive Heterocyclic Chemistry II; Katritzky, A. R.; Rees, C. W. Eds.; Elsevier: Amsterdam, 1996; Vol. 7, pp 431-488.

12. Elnagdi, M. H.; Abdel-Galil, F. M.; Riad, B. Y.; Elgemeie, G. E. H. Heterocycles 1983, $20,2437$.

13. Elmaati, T. M. A.; El-Taweel, F. M. J. Heterocycl. Chem. 2004, 41, 109.

14. Sadek, K. U.; Ali Selim, M.; Elnagdi, M. H.; Otto, H. H. Bull. Chem. Soc. Jpn. 1993, 66, 2927.

15. Furukawa, M.; Yuki, T.; Hayashi, S. Chem. Pharm. Bull. 1973, 21, 1845.

16. (a) Cai, J.; Jiang H.; Lin, X. Huagong Shikan 2006, 20, 15. (b) Ege, G.; Franz, H. J. Heterocycl. Chem. 1982, 19, 1267.

17. Pask, C. M.; Camm, K. D.; Kilner, C. A.; Halcrow, M. A. Tetrahedron Lett. 2006, 47, 2531.

18. Elnagdi, M. H.; Fleita, D. H.; El-Moghayar, M. R. H. Tetrahedron 1975, 31, 63.

19. Elnagdi, M. H.; El-Moghayar, M. R. H.; Fleita, D. H.; Hafez, E. A. A.; Fahmy, S. M. J. Org. Chem. 1976, 41, 3781.

20. Riyadh, S. M.; Al-Matar, H. M.; Elnagdi, M. H. Molecules 2008, 13, 3140. 
21. Shawali, A. S.; Hassaneen, H. M. Tetrahedron 1973, 29, 121.

22. Dorn, H.; Zubek, A. Org. Synth. 1968, 48, 8.

23. Hillers, S.; Eremeev, A. V.; Kalvins, I.; Liepins, E.; Tikhomirov, D. A. Khim. Geterotsikl. Soedin. 1975, 246.

24. (a) Salaheldin, A. M.; Alphy, M. K. J. Heterocycl. Chem. 2008, 45, 307. (b) Wang, T.; Lamb, M. L.; Scott, D. A.; Wang, H.; Block, M. H.; Lyne, P. D.; Lee, J. W.; Davies, A. M.; Zhang, H.-J.; Zhu, Y.; Gu, F.; Han, Y.; Wang, B.; Mohr, P. J.; Kaus, R. J.; Josey, J. A.; Hoffmann, E.; Thress, K.; MacIntyre, T.; Wang, H.; Omer, C. A.; Yu, D. J. Med. Chem. 2008, 51, 4672. (c) Mukaiyama, H.; Nishimura, T.; Shiohara, H.; Kobayashi, S.; Komatsu, Y.; Kikuchi, S.; Tsuji, E.; Kamada, N.; Ohnota, H.; Kusama, H. Chem. Pharm. Bull. 2007, 55, 881. (d) Abdelhamid, A. O.; Baghos, V. B.; Halim, M. M. A. J. Chem. Res. 2007, 420.

25. Li, J. R.; Zhang, L. J.; Chen, J. N.; Yang, X. Q.; Wang, L. J.; Zhao, X. F.; Qiu, J. X. Chin. Chem. Lett. 2007, 18, 636.

26. (a) Wang, X.; Kolasa, T.; El Kouhen, O. F.; Chovan, L. E.; Black-Shaefer, C. L.; Wagenaar, F. L.; Garton, J. A.; Moreland, R. B.; Honore, P.; Lau, Y. Y.; Dandliker, P. J.; Brioni, J. D.; Stewart, A. O. Bioorg. Med. Chem. Lett. 2007, 17, 4303. (b) Bondock, S.; Rabie, R.; Etman, H. A.; Fadda, A. Eur. J. Med. Chem. 2008, 43, 2122. (c) Quiroga, J.; Portilla, J.; Abonia, R.; Insuasty, B.; Nogueras, M.; Cobo, J. Tetrahedron Lett. 2008, 49, 5943.

27. (a) Das, J.; Moquin, R. V.; Pitt, S.; Zhang, R.; Shen, D. R.; McIntyre, K. W.; Gillooly, K.; Doweyko, A. M.; Sack, J. S.; Zhang, H.; Kiefer, S. E.; Kish, K.; McKinnon, M.; Barrish, J. C.; Dodd, J. H.; Schieven, G. L.; Leftheris, K. Bioorg. Med. Chem. Lett. 2008, 18, 2652. (b) Gupta, S.; Rodrigues, L. M.; Esteves, A. P.; Oliveira-Campos, A. M. F.; Nascimento, M. S. J.; Nazareth, N.; Cidade, H.; Neves, M. P.; Fernandes, E.; Pinto, M.; Cerqueira, N. M. F. S. A.; Bras, N. Eur. J. Med. Chem. 2008, 43, 771. (c) Daniels, R. N.; Kim, K.; Lebois, E. P.; Muchalski, H.; Hughes, M.; Lindsley, C. W. Tetrahedron Lett. 2008, 49, 305.

28. Ducray, R.; Ballard, P.; Barlaam, B. C.; Hickinson, M. D.; Kettle, J. G.; Ogilvie, D. J.; Trigwell, C. B. Bioorg. Med. Chem. Lett. 2008, 18, 959.

29. (a) Schmidt, P.; Druey, J. Helv. Chim. Acta 1956, 39, 986. (b) Saito, K.; Hori, I.; Igarashi, M.; Midorikawa, H. Bull. Chem. Soc. Jap. 1974, 47, 476.

30. (a) Kopp, M.; Lancelot, J.-C.; Dallemagne, P.; Rault, S. J. Heterocycl. Chem. 2001, 38, 1045. (b) Peet, N. P.; Lentz, N. L.; Sunder, S.; Dudley, M. W.; Ogden, A. M. L. J. Med. Chem. 1992, 35, 3263.

31. (a) Hassaneen, H. M. E. Synth. Commun. 2007, 37, 3579. (b) Tupper, D. E.; Bray, M. R. Synthesis $1997,337$.

32. Abdel-Khalik, M. M.; Agamya, S. M.; Elnagdi, M. H. Z. Naturforsch., B: Chem. Sci. 2000, 55, 1211.

33. Gopalsamy, A.; Yang, H.; Ellingboe, J. W.; Tsou, H.-R.; Zhang, N.; Honores, E.; Powell, D.; Miranda, M.; McGinnis, J. P.; Rabindran, S. K. Bioorg. Med. Chem. Lett. 2005, 15, 1591.

34. Etzbach, K. H.; Eilingsfeld, H. Synthesis 1988, 449.

35. (a) Markwalder, J. A.; Arnone, M. R.; Benfield, P. A.; Boisclair, M.; Burton, C. R.; Chang, C.-H.; Cox, S. S.; Czerniak, P. M.; Dean, C. L.; Doleniak, D.; Grafstrom, R.; Harrison, B. A.; Kaltenbach, R. F., III; Nugiel, D. A.; Rossi, K. A.; Sherk, S. R.; Sisk, L. M.; Stouten, P. Trainor, G. L.; Worland, P.; Seitz, S. P. J. Med. Chem. 2004, 47, 5894. (b) Gatta, F.; Luciani, M.; Palazzo, G. J. Heterocycl. 
Chem. 1989, 26, 613. (c) Earl, R. A.; Pugmire, R. J.; Revankar, G. R.; Townsend, L. B. J. Org. Chem. 1975, 40, 1822.

36. Yamada, Y.; Yasuda, H.; Yoshizawa, K. Heterocycles 1998, 48, 2095.

37. Wilson, R. D.; Watson, S. P.; Richards, S. A. Tetrahedron Lett. 1998, 39, 2827.

38. El-Agamey, A. G. A.; El-Sakka, I.; El-Shahat, Z.; Elnagdi, M. H. Arch. Pharm. 1984, 317, 289.

39. Salman, H. M. A.; Mohamed, A. A.; Ibrahim, S. A.; Ahmed, A. A. Bull. Fac. Sci., Assiut Univ. B 2000, 29, 25.

40. (a) Suryakiran, N.; Reddy, T. S.; Latha, K. A.; Prabhakar, P.; Yadagiri, K.; Venkateswarlu, Y. J. Mol. Catal. A: Chem. 2006, 258, 371. (b) Bagley, M. C.; Davis, T.; Dix, M. C.; Widdowson, C. S.; Kipling, D. Org. Biomol. Chem. 2006, 4, 4158. (c) Joshi, K. C.; Pathak, V. N.; Garg, U. J. Heterocycl. Chem. 1979, 16, 1141.

41. Pask, C. M.; Camm, K. D.; Kilner, C. A.; Halcrow, M. A. Tetrahedron Lett. 2006, 47, 2531.

42. Dastrup, D. M.; Yap, A. H.; Weinreb, S. M.; Henry, J. R.; Lechleiter, A. J. Tetrahedron, 2004, 60, 901.

43. Nie, Z.; Perretta, C.; Erickson, P.; Margosiak, S.; Lu, J.; Averill, A.; Almassy, R.; Chu, S. Bioorg. Med. Chem. Lett. 2008, 18, 619.

44. Anwar, H. F.; Fleita, D. H.; Kolshorn, H.; Meier, H.; Elnagdi, M. H. ARKIVOC 2006, (xv), 133.

45. (a) Abdallah, S. O.; Metwally, N. H.; Anwar, H. F.; Elnagdi, M. H. J. Heterocycl. Chem. 2005, 42, 781. (b) Shawali, A. S.; Abdelkader, M. H.; Eltalbawy, F. M. A. Tetrahedron 2002, 58, 2875. (c) Shawali, A. S.; Parkanyi, C. J. Heterocyclic. Chem. 1980, 17, 833. (d) Kolosov, M. A.; Orlov, V. D.; Kolos, N. N.; Shishkin, O. V.; Zubatyuk, R. I. ARKIVOC 2007, (xvi), 187.

46. Ege, G.; Pros, M. DE 93-4333659, 1995.

47. Abunada, N. M.; Hassaneen, H. M.; Kandile, N. G.; Miqdad, O. A. Molecules 2008, 13, 1501.

48. Atlan, V.; Buron, C.; Kaim, L. E. Synlett 2000, 489.

49. Ryckmans, T.; Viehe, H.-G.; Feneau-Dupont, J.; Tinant, B.; Declercq, J.-P. Tetrahedron 1997, 53, 1729.

50. Sanz, D.; Claramunt, R. M.; Elguero, J.; Salazar, L.; Espada, M. J. Chem. Soc., Perkin Trans. 1 $1990,809$.

51. Dodd, D. S.; Martinez, R. L. Tetrahedron Lett. 2004, 45, 4265.

52. Pace, A.; Buscemi, S.; Vivona, N.; Caronna, T. Heterocycles 2000, 53, 183.

53. (a) Majid, T.; Hopkins, C. R.; Pedgrift, B.; Collar, N. Tetrahedron Lett. 2004, 45, 2137. (b) Zabierek, A. A.; Konrad, K. M.; Haidle, A. M. Tetrahedron Lett. 2008, 49, 2996.

54. Fiamegos, Y. C.; Pilidis, G. A.; Varvounis, G. J. Heterocycl. Chem. 2001, 38, 1065.

55. Baxendale, I. R.; Ley, S. V. Bioorg. Med. Chem. Lett. 2000, 10, 1983.

56. El-Abadelah, M. M.; Sabri, S. S.; Khanfar, M. A.; Yasin, H. A.; Voelter, W. J. Heterocycl. Chem. 2002, 39, 1055.

57. (a) Rollas, S.; Ergenc, N.; Oral, B.; Kaymakcioglu, B. K.; Ozaltin, E. J. Fac. Pharm. Istanbul Univ. 2006, 38, 71. (b) Rollas, S. Marmara Univ. Eczacilik Derg. 1985, 1, 59.

58. Goncalves, M. S. T.; Oliveira-Campos, A. M. F.; Rodrigues, L. M.; Proenca, M. F. R. P.; Griffiths, J.; Maia, H. L. S.; Kaja, M.; Hrdina, R. J. Chem. Res. 2004, 115.

59. Abdel-Motaleb, R. M.; Abdel-Moneim, A. M.; Ibrahim, H. M.; Elnagdi, M. H. J. Heterocycl. Chem. 
2006, 43, 931.

60. Abdel-Motaleb, R. M.; Abdel-Salam Makhloof, A.-M.; Ibrahim, H. M.; Elnagdi, M. H. J. Heterocycl. Chem. 2007, 44, 109.

61. Ibrahim, H. M.; Makhseed, S.; Abdel-Motaleb, R. M.; Abdel-Salam Makhlouf, A.-M.; Elnagdi, M. H. Heterocycles 2007, 71, 1951.

62. Riyadh, S. M.; Abdelhamid, I. A.; Ibrahim, H. M.; Al-Matar, H. M.; Elnagdi, M. H. Heterocycles 2007, 71, 2545.

63. (a) Tarzia, G.; Panzone, G.; Leali, M.; Burdisso, M.; Schiatti, P.; Selva, D. Farmaco, Ed. Sci. 1984, 39, 538. (b) Fagan, P. J.; Neidert, E. E.; Nye, M. J.; O'Hare, M. J.; Tang, W.-P. Can. J. Chem. 1979, $57,904$.

64. (a) Simunek, P.; Svobodova, M.; Bertolasi, V.; Machacek, V. Synthesis 2008, 1761. (b) Hlimi, F.; Kerbal, A.; Laude, B.; Vebrel, J. C. R. Acad. Sci., Ser. 2 1988, 306, 1437.

65. Takahashi, M.; Kikuchi, H. Tetrahedron Lett. 1987, 28, 2139.

66. Chen, C.; Wilcoxen, K.; McCarthy, J. R. Tetrahedron Lett. 1998, 39, 8229.

67. Al-Mousawi, S. M.; El-Apasery, M. A.; Al-Kanderi, N. H. ARKIVOC 2008, (xvi), 268.

68. (a) Boulton, A. J.; Fruttero, R.; Saka, J. D. K.; Williams, M. T. J. Chem. Soc., Perkin Trans. 1 1986, 1249. (b) Sliskovic, D. R.; Siegel, M.; Lin, Y. I. Synthesis, 1986, 71.

69. Ohsawa, A.; Arai, H.; Ohnishi, H.; Itoh, T.; Kaihoh, T.; Okada, M.; Igeta, H. J. Org. Chem. 1985, $50,5520$.

70. von Rothenburg, R. Chem. Ber. 1894, 27, 685.

71. Sato, T. J. Org. Chem. 1959, 24, 963.

72. Taylor, E. C.; Hartke, K. S. J. Am. Chem. Soc. 1959, 81, 2456.

73. (a) Elnagdi, M. H. Tetrahedron 1974, 30, 2791. (b) Elnagdi, M. H.; Abd Allah, S. O. J. Prakt. Chem. 1973, 315, 1009. (c) Fahmy, S. M.; El-Hosami, M.; El-Gamal, S.; Elnagdi, M. H. J. Chem. Technol. Biotechnol. 1982, 32, 1042.

74. (a) Settepani, J. A.; Stokes, J. B. J. Org. Chem., 1968, 33, 2606. (b) Krystof, V.; Cankar, P.; Frysova, I.; Slouka, J.; Kontopidis, G.; Dzubak, P.; Hajduch, M.; Srovnal, J.; de Azevedo, W. F., Jr.; Orsag, X. M.; Paprskarova, M.; Rolcik, J.; Latr, A.; Fischer, P. M.; Strnad, M. J. Med. Chem. 2006, 49, 6500. (c) Cankar, P.; Frisova, I.; Krystof, V.; Lenobel, R.; Slouka, J.; Strnad, M.; Fishe, P. M. PCT Int. Appl. WO 2006024858, 2006.

75. Al-Mousawi, S. M.; Moustafa, M. S.; Elnagdi, M. H. Heterocycles 2008, 75, 1371.

76. Vaquero, J. J.; Fuentes, L.; Del Castillo, J. C.; Perez, M. I.; Garcia, J. L.; Soto, J. L. Synthesis 1987, 33.

77. Cocco, M. T.; Congiu, C.; Lilliu, V.; Onnis, V. Arch. Pharm. 2006, 339, 7.

78. (a) Abdelrazek, F. M.; Erian, A. W.; Hilmy, K. M. H. Synthesis 1986, 74. (b) Abdelrazek, F. M. J. Prakt. Chem. 1989, 331, 475.

79. Elnagdi, M. H.; El-Ghamry, I.; Kandeel, E.; Abdel Rahman, A. H.; Al-Naggar, A. A.; Amer, S.; Riad, M. Gazz. Chim. Ital. 1997, 127, 791.

80. Abdelrazek, F., M.; Mohamed, A. M. Afinidad 2008, 65, 56.

81. Al-Mousawi, S. M.; Moustafa, M. S.; Meier, H.; Kolshorn, H.; Elnagdi, M. H. Molecules 2009, 14, 798. 
82. Blass, B. E.; Srivastava, A.; Coburn, K. R.; Faulkner, A. L.; Seibel, W. L. Tetrahedron Lett. 2003, 44, 3009.

83. Chien, T.; Smaldone, R. A.; Townsend, L. B. Tetrahedron Lett. 2004, 45, 4105.

84. (a) Al-Shiekh, M. A.; El-Din, A. M. S.; Hafez, E. A.; Elnagdi, M. H. J. Chem. Res. 2004, 174. (b) El-Ghandour, A. H. H.; Ibrahim, M. K. A.; Abdel-Hafiz, I. S.; Elnagdi, M. H. Z. Naturforsch., B: Chem. Sci. 1992, 47, 1628. (c) Elnagdi, M. H.; Zayed, E. M.; Khalifa, M. A. E.; Ghozlan, S. A. Monatsh. Chem. 1981, 112, 245.

85. (a) Kocevar, M.; Kolman, D.; Krajnc, H.; Polanc, S.; Porovne, B.; Stanovnik, B.; Tisler, M. Tetrahedron 1976, 32, 725. (b) Joshi, K. C.; Pathak, V. N.; Garg, U. J. Indian Chem. Soc. 1983, 60, 1074. (c) Elagamey, A. G. A.; El-Taweel, F. M. A.; Amer, F. A. Collect. Czech. Chem. Commun. 1986, 51, 2193. (d) Dawood, K. M.; Farag, A. M.; Abdel-Aziz, H. A. J. Chem. Res. 2005, 378. (e) Al-Omran, F.; El-Khair, A. A. J. Chem. Res. 2006, 6.

86. Vilarrasa, J.; Granados, R. J. Heterocycl. Chem. 1974, 11, 867.

87. Elnagdi, M. H.; Elmoghayar, M. R. H.; Kandeel, E. M.; Ibrahim, M. K. A. J. Heterocycl. Chem. 1977, 14, 227.

88. (a) Ege, G.; Gilbert, K. Tetrahedron Lett. 1979, 1567. (b) Ege, G.; Gilbert, K.; Heck, R. Chem. Ber. 1984, 117, 1726.

89. Moyano, E. L.; Colomer, J. P.; Yranzo, G. I. Eur. J. Org. Chem. 2008, 3377.

90. Pavlov, I. V.; Kobrakov, K. I.; Bogza, S. L. Chem. Heterocycl. Compd. 2004, 40, 964.

91. Bogza, C. L.; Dulenko, V. I.; Zinchenko, S. Y.; Kobrakov, K. I.; Pavlov, I. V. Chem. Heterocycl. Compd. 2004, 40, 1506.

92. (a) Wu, Y.-C.; Zou, X.-M.; Hu, F.-Z.; Yang, H.-Z. J. Heterocycl. Chem. 2005, 42, 609. (b) Ege, G.; Gilbert, K. Tetrahedron Lett. 1979, 4253.

93. Elnagdi, M. H.; Zayed, E. M.; Abdou, S. Heterocycles 1982, 19, 559.

94. Cankar, P.; Slouka, J. Acta Univ. Palacki. Olomuc., Fac. Rerum Nat., Chem. 2000, 39, 15.

95. Tretyakov, E. V.; Knight, D. W.; Vasilevsky, S. F. J. Chem. Soc., Perkin Trans. 1 1999, 3721.

96. Ganesan, A.; Heathcock, C. H. J. Org. Chem. 1993, 58, 6155.

97. (a) Rudolph, J.; Wickens, P.; Chuang, C.-Y.; Chen, L.; Magnuson, S.; Olague, A.; Qi, N.; U.S. Pat. Appl. Publ. US 20050192294, 2005. (b) Sammelson, R. E.; Caboni, P.; Durkin, K. A.; Casida, J. E. Bioorg. Med. Chem. 2004, 12, 3345. (c) Dorn, H.; Dilcher, H. Justus Liebigs Ann. Chem. 1967, 707, 141. (d) Kim, M. M.; Ruck, R. T.; Zhao, D.; Huffman, M. A. Tetrahedron Lett. 2008, 49, 4026.

98. Salaheldin, A. M.; Oliveira-Campos, A. M. F.; Rodrigues, L. M.; Tetrahedron Lett. 2007, 48, 8819.

99. (a) Michon, V.; Herve du Penhoat, C.; Tombret, F.; Gillardin, J. M.; Lepage, F.; Berthon, L. Eur. J. Med. Chem. 1995, 30, 147. (b) Graubaum, H. J. Prakt. Chem. 1993, 335, 585.

100. Daidone, G.; Plescia, S.; Raffa, D.; Bajardi, M. L.; Milici, M. Farmaco, Ed. Sci. 1985, 40, 683.

101. Heil, M.; Bretschneider, T.; Militzer, H.-C.; Alig, B.; Mauler-Machnik, A.; Stenzel, K. Ger. Offen. DE 19838708, 2000.

102. El-Emary, T. I.; Al-Muaikel, N.; Moustafa, O. S. Phosphorus, Sulfur Silicon Relat. Elem. 2002, 177, 195.

103. Ryckmans, T.; Viehe, H.-G.; Feneau-Dupont, J.; Tinant, B.; Declercq, J.-P. Tetrahedron 1997, 53, 1729. 
104. (a) Bagley, M. C.; Davis, T.; Dix, M. C.; Widdowson, C. S.; Kipling, D. Org. Biomol. Chem. 2006, 4, 4158. (b) Winters, G.; Sala, A.; De Paoli, A.; Ferri, V. Synthesis 1984, 1052.

105. Schenone, S.; Bruno, O.; Bondavalli, F.; Ranise, A.; Mosti, L.; Menozzi, G.; Fossa, P.; Manetti, F.; Morbidelli, L.; Trincavelli, L.; Martini, C.; Lucacchini, A. Eur. J. Med. Chem. 2004, 39, 153.

106. Adams, N. D.; Schmidt, S. J.; Knight, S. D.; Dhanak, D. Tetrahedron Lett. 2007, 48, 3983.

107. (a) Elfahham, H. A.; Abdel-Galil, F. M.; Ibraheim, Y. R.; Elnagdi, M. H. J. Heterocycl. Chem. 1983, 20, 667. (b) Hussain, S. M.; El-Reedy, A. M.; El-Sharabasy, S. A. Tetrahedron 1988, 44, 241.

108. Elkholy, A.; Al-Qalaf, F.; Elnagdi, M. H. ARKIVOC 2008, (xiv), 124.

109. Hassaneen, H. M. E.; Hassaneen, H. M.; Khiry, S. F. M.; Pagni, R. M. Z. Naturforsch., B: Chem. Sci. 2008, 63, 217.

110. (a) Quiroga, J.; Portilla, J.; Abonia, R.; Insuasty, B.; Nogueras, M.; Cobo, J. Tetrahedron Lett. 2007, 48, 6352. (b) Quiroga, J.; Portilla, J.; Abonia, R.; Insuasty, B.; Nogueras, M.; Cobo, J. Tetrahedron Lett. 2008, 49, 6254. (c) Shidlovskii, A. F.; Peregudov, A. S.; Averkiev, B. B.; Antipin, M. Y.; Chkanikov, N. D. Russ. Chem. Bull. 2004, 53, 2060. (d) Wendt, M. D.; Kunzer, A.; Henry, R. F.; Cross, J.; Pagano, T. G. Tetrahedron Lett. 2007, 48, 6360.

111. (a) Chebanov, V. A.; Saraev, V. E.; Desenko, S. M.; Chernenko, V. N.; Knyazeva, I. V.; Groth, U.; Glasnov, T. N.; Kappe, C. O. J. Org. Chem. 2008, 73, 5110. (b) Shi, C.-L.; Shi, D.-Q.; Kim, S. H.; Huang, Z.-B.; Ji, S.-J.; Ji, M. Tetrahedron. 2008, 64, 2425. (c) Quiroga, J.; Portilla, J.; Serrano, H.; Abonia, R.; Insuasty, B.; Nogueras, M.; Cobo, J. Tetrahedron Lett. 2007, 48, 1987. (d) Chebanov, V. A.; Saraev, V. E.; Desenko, S. M.; Chernenko, V. N.; Shishkina, S. V.; Shishkin, O. V.; Kobzar, K. M.; Kappe, C. O. Org. Lett. 2007, 9, 1691.

112. Al-Mousawi, S. M.; Kaul, K.; Mohammad, M. A.; Elnagdi, M. H. J. Chem. Res. (s) 1997, 318.

113. Shi, D.-Q.; Yao, H.; Shi, J.-W. Synth. Commun. 2008, 38, 1662.

114. (a) Zhang, X. Y.; Li, X. Y.; Fan, S.; Wang, X.; Wang, J. J.; Qu, G. R. Chin. Chem. Lett. 2008, 19, 153. (b) Zhang, X.; Li, X.; Fan, X.; Wang, X.; Qu, G.; Wang, J. Heterocycles 2009, 78, 923.

115. (a) Quiroga, J.; Alvarado, M.; Insuasty, B.; Moreno, R.; Ravina, E.; Estevez, I.; De Almeida, R. H. J. Heterocycl. Chem. 1999, 36, 1311. (b) Elfahham, H. A.; Abdel-Galil, F. M.; Ibraheim, Y. R.; Elnagdi, M. H. J. Heterocycl. Chem. 1983, 20, 667.

116. Fan, X. S.; Wang, X.; Li, X. Y. Chin. Chem. Lett. 2008, 19, 643.

117. Jachak, M. N.; Avhale, A. B.; Ghotekar, B. K.; Kendre, D. B.; Toche, R. B. J. Heterocycl. Chem. 2008, 45, 1221.

118. (a) Lipson, V. V.; Karnozhitskaya, T. M.; Desenko, S. M.; Shishkina, S. V.; Shishkin, O. E.; Musatov, V. I. Russ. J. Org. Chem. 2007, 43, 249. (b) Lipson, V. V.; Desenko, S. M.; Shirobokova, M. G.; Shishkin, O. V.; Shishkina, S. V. Russ. J. Org. Chem. 2006, 42, 1022.

119. Al-Mousawi, S. M.; Mohammad, M. A.; Elnagdi, M. H. J. Heterocycl. Chem. 2001, 38, 989.

120. Li, M.; Wang, S.; Wen, L.; Yang, H.; Zhang, X. J. Heterocycl. Chem. 2005, 42, 925.

121. Al-Qalaf, F.; Abdelkhalik, M. M.; Al-Enezi, A.; Al-Ajmi, J. R. Heterocycles 2008, 75, 145.

122. Al-Afaleq, E. I. Synth. Commun. 2000, 30, 1985.

123. Hyssein, M. M. Mansoura Sci. Bull., A: Chem. 2002, $29,1$.

124. Al-Zaydi, K. M.; Al-Shiekh, M. A. A.; Hafez, E. A.-A. J. Chem. Res. (s) 2000, 13.

125. (a) Siripragada, M. R.; Upparapalli, S. K.; Kunchithapatham, T.; Subramaniyan, M. PCT Int. Appl. 
WO 2008068600, 2008. (b) Dusza, J. P.; Tomcufcik, A. S.; Albright, J. D. U.S. Patent 4626538, 1986.

126. (a) Yin, L.; Liebscher, J. Synthesis 2004, 2329. (b) Desenko, S. M.; Orlov, V. D.; Lipson, V. V.; Shishkin, O. V.; Potekhin, K. A.; Struchkov, Y. T. Khim. Geterotsikl. Soedin. 1993, 109. (c) Orlov, V. D.; Quiroga, H.; Kolos, N. N.; Desenko, S. M. Khim. Geterotsikl. Soedin. 1988, 962.

127. Bellec, C.; Lhommet, G. J. Heterocycl. Chem. 1995, 32, 1793.

128. Elnagdi, M. H.; Erian, A. W. Bull. Chem. Soc. Jpn. 1990, 63, 1854.

129. (a) Cebasek, P.; Bevk, D.; Pirc, S.; Stanovnik, B.; Svete, J. J. Comb. Chem. 2006, 8, 95. (b) Bevk, D.; Golic, L.; Golobic, A.; Svete, J.; Stanovnik, B. Heterocycles 2005, 66, 207. (c) Al-Saleh, B.; Makhseed, S.; Hassaneen, H. M. E.; Elnagdi, M. H. Synthesis 2006, 59.

130. Bekircan, O.; Kuxuk, M.; Kahveci, B.; Kolayli, S. Arch. Pharm. 2005, 338, 365.

131. Thomas, A.; Chakraborty, M.; Ila, H.; Junjappa, H. Tetrahedron 1990, 46, 577.

132. Gavrin, L. K.; Lee, A.; Provencher, B. A.; Massefski, W. W.; Huhn, S. D.; Ciszewski, G. M.; Cole, D. C.; McKew, J. C. J. Org. Chem. 2007, 72, 1043.

133. Tominaga, Y.; Yoshioka, N.; Kataoka, S.; Aoyama, N.; Masunari, T.; Miike, A. Tetrahedron Lett. 1995, 36, 8641 .

134. Chebanov, V. A.; Sakhno, Y. I.; Desenko, S. M.; Chernenko, V. N.; Musatov, V. I.; Shishkina, S. V.; Shishkin, O. V.; Kappe, C. O. Tetrahedron, 2006, 63, 1229.

135. Kiselyov A. S.; Smith, L. Tetrahedron Lett. 2006, 47, 2611.

136. Esteves-Souza, A.; Echevarria, A.; Vencato, I.; Jimeno, M. L.; Elguero, J. Tetrahedron 2001, 57, 6147.

137. Quiroga, J.; Portilla, J.; Insuasty, B.; Abonia, R.; Nogueras, M.; Sortino, M.; Zacchino, S. J. Heterocycl. Chem. 2005, 42, 61.

138. Jachak, M. N.; Avhale, A. B.; Tantak, C. D.; Toche, R. B.; Reidlinger, C.; Stadlbauer, W. J. Heterocycl. Chem. 2005, 42, 1311.

139. Jachak, M. N.; Avhale, A. B.; Medhane, V. J.; Toche, R. B. J. Heterocycl. Chem. 2006, 43, 1169.

140. Lacova, M.; Puchala, A.; Solcanyova, E.; Lac, J.; Kois, P.; Chovancova, J.; Rasala, D. Molecules 2005, 10, 809 .

141. (a) Sperandeo, N. R.; Brun, R. ChemBioChem 2003, 4, 69. (b) Sperandeo, N. R.; de Bertorello, M. M. Molecules 2000, 5, 508 .

142. (a) Dang, Q.; Liu, Y.; Sun, Z. Tetrahedron Lett. 2001, 42, 8419. (b) Dang, Q.; Brown, B. S.; Erion, M. D. J. Org. Chem. 1996, 61, 5204.

143. Kanth, S. R.; Reddy, G. V.; Maitraie, D.; Narsaiah, B.; Rao, P. S.; Kumar, K. R.; Sridhar, B. J. Fluorine Chem. 2006, 127, 1211.

144. (a) Elfahham, H. A.; Abdel-Latif, F. F.; Mohamed, S. K. Indian J. Chem., Sect. B 1990, $29 B, 381$.

(b) Elfahham, H. A.; Elgemeie, G. E. H.; Ibraheim, Y. R.; Elnagdi, M. H. Liebigs Ann. Chem. 1988, 819. (c) Elgemeie, G. E. H.; Elfahham, H. A.; Ghozlan, S. A. S.; Elnagdi, M. H. Bull. Chem. Soc. Jpn. 1984, 57, 1650.

145. Graf, H.; Klebe, G. Chem. Ber. 1987, 120, 965.

146. Elnagdi, M. H.; Elmoghayer, M. R. H.; Sadek, K. U. Adv. Heterocycl. Chem. 1990, 48, 223.

147. (a) Guerrini, G.; Ciciani, G.; Cambi, G.; Bruni, F.; Selleri, S.; Besnard, F.; Montali, M.; Martini, C.; 
Ghelardini, C.; Galeotti, N.; Costanzo, A. Bioorg. Med. Chem. 2007, 15, 2573. (b) Guerrini, G.; Costanzo, A.; Ciciani, G.; Bruni, F.; Selleri, S.; Costagli, C.; Besnard, F.; Costa, B.; Martini, C.; De Siena, G.; Malmberg-Aiello, P. Bioorg. Med. Chem. 2006, 14, 758. (c) Costanzo, A.; Guerrini, G.; Bruni, F.; Selleri, S. J. Heterocycl. Chem. 1994, 31, 1369.

148. Wang, T.; Lamb, M. L.; Scott, D. A.; Wang, H.; Block, M. H.; Lyne, P. D.; Lee, J. W.; Davies, A. M.; Zhang, H.-J.; Zhu, Y.; Gu, F.; Han, Y.; Wang, B.; Mohr, P. J.; Kaus, R. J.; Josey, J. A.; Hoffmann, E.; Thress, K.; MacIntyre, T.; Wang, H.; Omer, C. A.; Yu, D. J. Med. Chem. 2008, 51, 4672.

149. Menegatti, R.; Silva, G. M. S.; Zapata-Sudo, G.; Raimundo, J. M.; Sudo, R. T.; Barreiro, E. J.; Fraga, C. A. M. Bioorg. Med. Chem. 2006, 14, 632.

150. Nie, Z.; Perretta, C.; Erickson, P.; Margosiak, S.; Almassy, R.; Lu, J.; Averill, A.; Yager, K. M.; Chu, S. Bioorg. Med. Chem. Lett. 2007, 17, 4191.

151. Tyurin, R. V.; Vorob'ev, E. V.; Minyaeva, L. G.; Krasnikov, V. V.; Mezheritskii, V. V. Russ. J. Org. Chem. 2005, 41, 916.

152. (a) Maquestiau, A.; Vanden Eynde, J. J. Tetrahedron 1987, 43, 4185. (b) Maquestiau, A.; Vanden Eynde, J. J. Tetrahedron 1987, 43, 4195.

153. (a) Bulychev, Y. N.; Korbukh, I. A.; Preobrazhenskaya, M. N.; Chernyshov, A. I.; Esipov, S. E. Khim. Geterotsikl. Soedin. 1984, 259. (b) Bulychev, Y. N.; Korbukh, I. A.; Preobrazhenskaya, M. N. Khim. Geterotsikl. Soedin. 1982, 1682.

154. Dalinger, I. L.; Vatsadse, I. A.; Shevelev, S. A.; Ivachtchenko, A. V. J. Comb. Chem. 2005, 7, 236.

155. Yachevskii, D. S.; Chizhov, D. L.; Charushin, V. N. Russ. J. Org. Chem. 2006, 42, 142.

156. Lipson, V. V.; Shirobokova, M. G.; Shishkin, O. V.; Shishkina, S. V. Russ. J. Org. Chem. 2006, 42, 1015.

157. Zhang, H.-Z.; Claassen, G.; Crogran-Grundy, C.; Tseng, B.; Drewe, J.; Cai, S. X. Bioorg. Med. Chem., 2008, 16, 222.

158. Salaheldin, A. M.; Abdallah, T. A.; Radwan, N. F.; Hassaneen, H. M. Z. Naturforsch., B: Chem. Sci. 2006, 61, 1158.

159. Eggenwiler, H. PCT Int. Appl. WO 200259126, 2002.

160. Saibal, K. D.; Purma, P. R.; Akella, V.; Ramanujam, R.; Ranjan, C.; Lohray, B. B.; Lohray, V. B.; Paraselli, B. R. PCT Int. Appl. WO 200262799, 2002.

161. Reddy, N. R.; Reddy, G. M.; Reddy, B. S.; Reddy, P. P. J. Heterocycl. Chem. 2005, 42, 751.

162. Berestevich, B. K. SU 1456433, 1989.

163. Okatani, T.; Koyama, J.; Tagahara, K. Heterocycles, 1989, 29, 1809.

164. (a) Osawa, A.; Kaiho, T.; Ito, T.; Okada, M.; Kawabata, C.; Yamaguchi, K.; Igeta, H. Chem. Pharm. Bull. 1988, 36, 3838. (b) Kaihoh, T.; Itoh, T.; Ohsawa, A.; Okada, M.; Kawabata, C.; Igeta, H. Chem. Pharm. Bull. 1987, 35, 3952. 


\section{Author's biography}

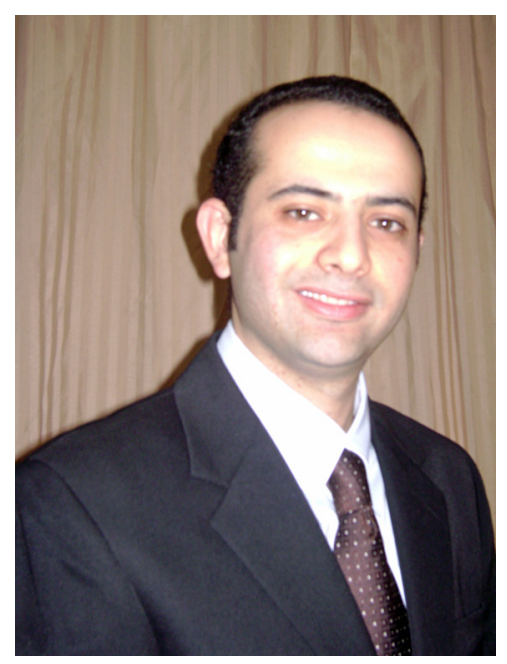

Hany Fakhry Anwar was born in Cairo, Egypt, in 1979. He received his B.Sc. in chemistry (2001) and his M.Sc. in organic chemistry (2005) from Cairo University. Recently, he received his Ph.D. from the School of Pharmacy, Department of Pharmaceutical Chemistry, Oslo University. Hany F. Anwar has published ten research papers in organic chemistry. His research interests focus on the synthesis of heterocyclic compounds and natural products, and synthesis of molecules with biological activity.

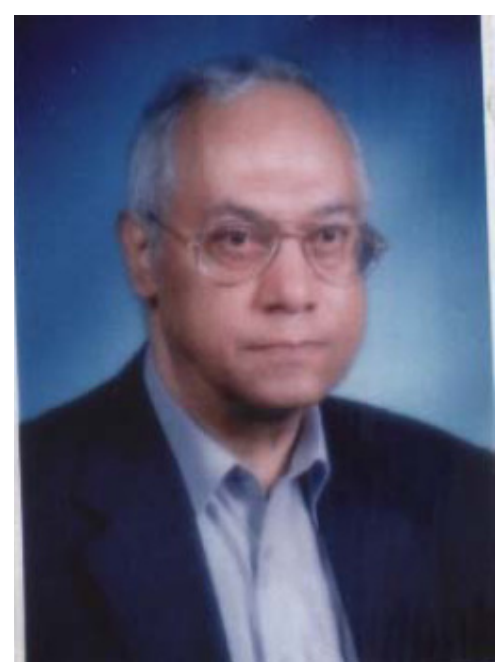

Mohamed Hilmy EInagdi was born in Egypt in September 1941. He graduated from the Faculty of Science at Cairo University in 1962; since that date, Prof. Elnagdi has worked at Cairo University, Faculty of Science, in the Chemistry Department. Prof. Elnagdi obtained his M.Sc. in 1966, Ph.D. in 1969, and D.Sc. in 1982. He has also been awarded a Diploma in Applied Chemistry from Tokyo Institute of Technology in 1973. Prof. Elnagdi has been professor of organic chemistry at Cairo University since 1980 . He worked as professor of organic chemistry 
at Kuwait University from 1993 to 1999 , then as visiting professor at the same university in 2003. Prof. Elnagdi has received fellowships from several institutions, including NTNF Norway taken at University of Oslo (1977); Visiting Associate Professor at the University of Utah in 1976 with Prof. L. B. Townsend; Alexander von Humboldt Fellowship at the University of Bonn with Profs. H. Wamhoff and R. Regitz. The Alexander von Humboldt Foundation has continually supported his activities in Germany, enabling him to cooperate with many German colleagues including Profs. K. Hafner, K. S. Hartki, M. Hoffmann, and H. H. Otto. Prof. Elnagdi has specialized in the synthesis of polyfunctional heterocycles and has published around 350 papers in this area as well as 15 review articles. In addition, he got several national and regional research awards and published several books. 